PENINGKATAN HASIL BELAJAR MATEMATIKA MELALUI MODEL PEMBELAJARAN AUDITORY, INTELLECTUALLY, REPETITION (AIR) PADA SISWA KELAS V SD INPRES PERUMNAS ANTANG II/I KOTA MAKASSAR

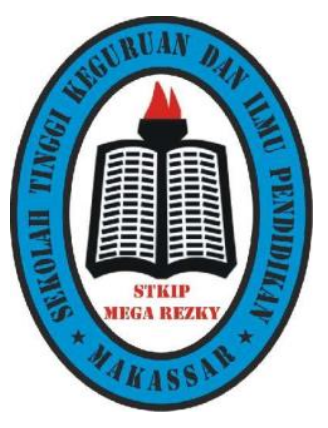

SITI NURFAIDAH

PROGRAM STUDI PENDIDIKAN GURU SEKOLAH DASAR SEKOLAH TINGGI KEGURUAN DAN ILMU PENDIDIKAN (STKIP) MEGA REZKY MAKASSAR 2018 


\title{
PENINGKATAN HASIL BELAJAR MATEMATIKA MELALUI MODEL PEMBELAJARAN AUDITORY, INTELLECTUALLY, REPETITION (AIR) PADA SISWA KELAS V SD INPRES PERUMNAS ANTANG II/I KOTA MAKASSAR
}

\author{
SKRIPSI \\ Diajukan kepada Program Studi Pendidikan Guru Sekolah Dasar \\ STKIP Mega Rezky Makassar Sebagai Salah Satu Syarat \\ Untuk Mencapai Gelar Sarjana Pendidikan
}

Oleh

SITI NURFAIDAH

093188793042

PROGRAM STUDI PENDIDIKAN GURU SEKOLAH DASAR SEKOLAH TINGGI KEGURUAN DAN ILMU PENDIDIKAN (STKIP) MEGA REZKY MAKASSAR 2018 


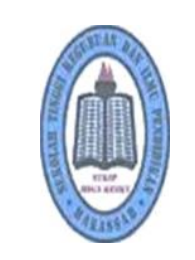

SEKOLAH TINGGI KEGURtIAN OAN ILMIJ PENDIOIKAN (STKIP) \IEGA REZKI MAKASSAR

\section{HALAMAN PESGESAHAS}

Słripsi dengan judul "Peninj;kaan Hasil Pelajar Mateniatika Melalui Model Pem§elaj3ran /uJili>ry. liik'IIecliinIIy, Itepeiiiioii (AIR) Pada Siswa Kelas Y SD Inpres Perumnas Antang II/I Koa Makassar" atas nama Siti Nurfaidah, NIM 09SI8879S042 diterima dan disabkan oleh panitia yjian skripsi berdasarkan surat keputusan Ketua Sekolah Tinggi Ke§qrrzn Da» llmv Pendidikan (STKIP) Mega Rezky Md<assar Nomor: 017/SIP/09JI88/111/2018 anggal 29 Marzt 20I8 sr8agai Sdl21t M(IJ Sl3fd( gM6 MCITl]Xf0lCfl ggl8f b8fj6fl3 \#efldi\#i)t8fl @\#3 \#f0gMM Stugi Saqanz Pendidikan Guru Sekolah Dasar (PGSD) Sekolah Tinggi Kegunian Dan Ilmu Pendidikan (STKIP) Mciz Rezky Makassai.

Makass8r, November t018

$\underline{\text { Panitia Uiian, }}$

I. Ketua :Jusmawati, S.7d., M.Fd

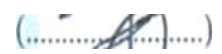

2. Sekreoris : : 8erawati Bte Abustang, S.Pd., M.I'd

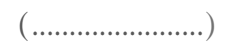

3. Dosen Fenguji : a. Bellona M8rdhatillati Sabillah S.Pd.,

h. Drs. Kasan Sinking, M.M
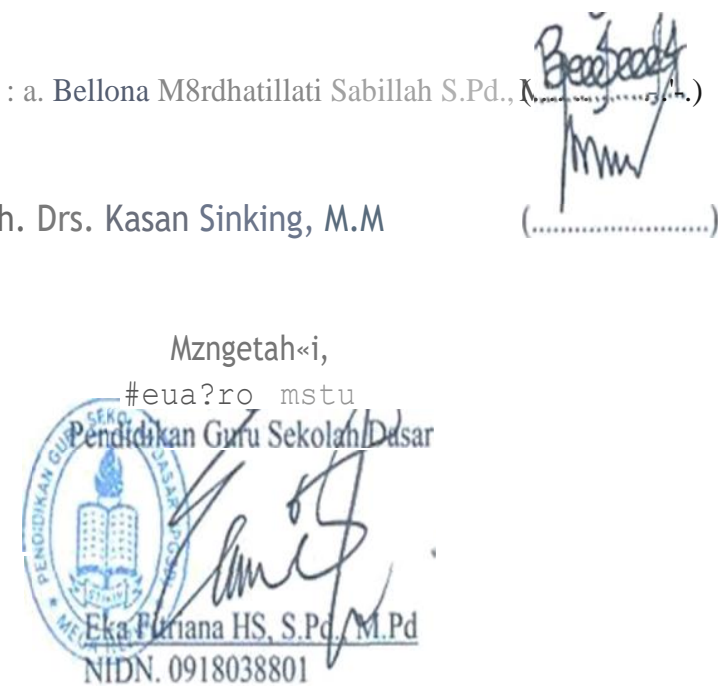


\section{I'EkXYXTAAN KEXSLIñfi SXRI7SI}

Satu, PITI ñLRFAIDAH, Nomor PoLot: @31887fi30t2, mcn〉atakan bafi» 'z skripsi yang bcrjudul: Peniaglutan Hasil Belsjar IIsttnatika 'IfeIslui ñl0étl f'eMbelajnran A«\#ilon', IsleIlecIxsII', Re\#eiiiioii (AIR) Pada Siswa Kelas V SD Inprts Ferumnxs Antang II/I Kate Mxkassxr, dibin bing oleh(I) Jusma>vati, S,Pd., M.Pd dan (2) Pera yzti Btc Abustzng, S.Pd., M.Pd menipzkan karya asli. Seluruh ide yang ada dalam skripsi ini, kecuali yang saya nyatakan sebagai kutipan, merupakan ide yang saya susun sendiri. Selain itu, tidak ada bagian dari skripsi ini yang telah saya gunakan sebelumnya untuk memperoleh gclar atau se0ifikat aLademik.

lima qmyatax di as teAufli sebaliknya, maha aya knedia meneima sa»tsi tang ditctatka» oleh STKIP Mega Rezky Makassar.

Malıassar, Noveni\&i ?018

Yxgm<mbatgmyat $n$

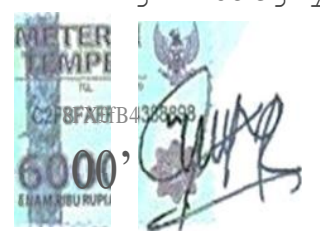

Siti Nurfaidsh

NIM. 09J18t79>042 


\section{MOTTO DAN PERSEMBAHAN}

"Jangan berputus asa, sesungguhnya bersama kesabaran pasti ada keberhasilan"

"Bersyukurlah maka Tuhan akan memperbaiki hidupmu"

Bersyukurlah atas apa yang engkau miliki

dan jadilah dirimu sendiri,

maka kau akan bahagia

Kupersembahkan karya ini sebagai Dharma Baktiku kepada orang tuaku, saudara-saudaraku tercinta dan sahabat-sahabatku yang telah mendoakan, mendukung, dan membantu dengan penuh selama menempuh pendidikan 


\begin{abstract}
ABSTRAK
SITI NURFAIDAH, 2018. Peningkatan Hasil Belajar Matematika Melalui Model Pembelajaran Auditory, Intellectually, Repetition (AIR) Pada Siswa Kelas V SD Inpres Perumnas Antang II/I Kota Makassar. Skripsi dibimbing oleh Jusmawati dan Perawati Bte Abustang.

Permasalahan dalam penelitian ini adalah rendahnya hasil belajar matematika siswa kelas V SD Inpres Perumnas Antang II/I Kota Makassar. Tujuan dilaksanakan penelitian ini, yaitu untuk mengetahui model pembelajaran Auditory, Intellectualy, Repetition (AIR) dapat meningkatkan hasil belajar pada siswa kelas V SD Inpres Perumnas Antang II/I Kota Makassar dengan menggunakan pendekatan mix method. Jenis penelitian yang digunakan adalah Penelitian Tindakan Kelas (PTK) yang berdaur ulang/siklus dengan fokus yaitu penerapan model pembelajaran Auditory, Intellectualy, Repetition (AIR) dan hasil belajar matematika. Subjeknya adalah siswa kelas V SD Inpres Perumnas Antang II/I Kota Makassar yang aktif terdaftar pada semester genap tahun ajaran 2018/2019 dengan jumlah siswa sebanyak 30 orang. Rancangan tindakan dalam penelitian ini meliputi perencanaan tindakan, pelaksanaan, observasi, dan refleksi. Teknik pengumpulan data dilakukan melalui tes, observasi, dan dokumentasi. Paparan data hasil menunjukkan bahwa hasil belajar siswa mengalami peningkatan yang signifikan pada tiap siklus yang ditandai cukup pada siklus I kemudian meningkat pada siklus II hingga mencapai kualifikasi sangat baik. Berdasarkan hasil yang dipeoleh, disimpulkan bahwa terjadi peningkatan yang signifikan terhadap hasil belajar matematika siswa kelas V SD Inpres Perumnas Antang II/I Kota Makassar melalui model pembelajaran Auditory, Intellectualy, Repetition (AIR).
\end{abstract}

Kata Kunci : Model Pembelajaran Auditory, Intellectually, Repetition (AIR), Matematika, Siswa Kelas V, Hasil Belajar 


\begin{abstract}
SITI NURFAIDAH, 2018. " The Improvement of Mathematics Learning Outcomes through Auditory, Intellectually, Repetition (AIR) Learning Model For The Fifth Grade Students Of Elementary School Inpres Perumnas Antang II/I Of Makassar." Supervised by Jusmawati and Perawati Bte Abustang.

The problem in this research is the low level of mathematics learning outcomes of the fifth grade students of elementary school Inpres Perumnas Antang II / I Of Makassar. This research aimed to know the improvement of mathematics learning outcomes through the Auditory, Intellectually, Repetition (AIR) learning model for the fifth grade students of elemtary school Inpres Perumnas Antang II/I of Makassar by using mix method approach. The type of this research used classsroom action research which recycle/cycle with focus, namely the application of Auditory, Intellectually, Repetition (AIR) learning models and mathematics learning outcomes. The subjects of this research were the fifth grade students of elementary school Inpres Perumnas Antang II/I of Makassar registered in the even semester of 2018/2019 school year with the number of students as many 30 students. Action plans in this research include action planning, implementation, observation and reflection. The data collection technique was conducted by test, observation and documentation. The result of exposure data showed that student learning outcomes experienced a significant increase in each cycle marked enough in cycle I then increased in cycle II to achieve very good qualifications.
\end{abstract}

Keywords: The Auditory, Intellectually, Repetition (AIR) learning model, Mathematics, The Fifth Grade Students, Learning Outcomes.

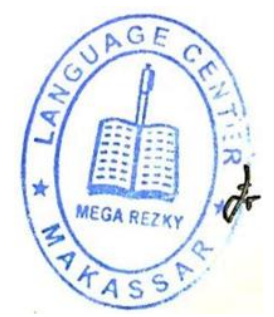




\section{KATA PENGANTAR}

Alhamdulillahirobil'alamiin, puji dan syukur penulis panjatkan kehadirat Allah SWT karena atas rahmat, taufik dan hidayahnya sehingga penulis dapat melakukan penelitian dan menyelesaikan penelitian skripsi dengan judul "Peningkatan Hasil Belajar Matematika Melalui Model Pembelajaran Auditory, Intellectually, Repetition (AIR) Pada Siswa Kelas V SD Inpres Perumnas Antang II/I Kota Makassar". Skripsi ini dibimbing oleh Jusmawati, S.Pd., M.Pd selaku pembimbing I dan Perawati BTE Abustang, S.Pd., M.Pd. selaku pembimbing II yang selama ini meluangkan waktunya dalam memberikan bimbingan dan arahan dalam penulisan skripsi ini.

Penulis menyadari banyak saran dan kritik yang bersifat membangun dari berbagai pihak, sehingga mendorong penulis untuk bekerja lebih giat dalam menyelesaikan skripsi ini. Pada kesempatan ini penulis dengan kerendahan hati menyampaikan ucapan terima kasih yang setinggi-tingginya kepada:

1. Ibu Hj. Suryani, S.H., M.H selaku Ketua Yayasan Pendidikan Islam Mega Rezky Makassar

2. Bapak Dr. Abdul Malik Iskandar, S.Ag., M.Si, selaku Ketua STKIP Mega Rezky Makassar.

3. Bapak Waket I, Waket II dan Waket III STKIP Mega Rezky Makassar.

4. Ibu Eka Fitriana HS, S.Pd., M.Pd, selaku Ketua Program Studi PGSD.

5. Bapak Irman R, S.Pd., M.Pd selaku Pembimbing Akademik yang selalu memberikan motivasi, pengetahuan dan nasehatnya.

6. Ibu Bellona Mardhatillah Sabillah, S.Pd., M.Pd selaku penguji I dan Bapak Drs. Kasman Sinring, M.M selaku penguji II yang telah memberikan saran dan masukan yang sangat berarti bagi penulis. 
7. Bapak dan Ibu Dosen Program Studi PGSD yang telah memberikan bekal ilmu dan pengetahuan yang sangat berarti.

8. Bapak/Ibu staf STKIP Mega Rezky Makassar yang telah memberikan ilmu pengetahuan, bantuan dan pelayanan administrasi.

9. Ibu Suharniati, S.Pd selaku Kepala SD Inpres Perumnas Antang II/I Kota Makassar beserta staf pengajar yang dengan senang hati telah menerima dan membantu penulis dalam melakukan penelitian.

10. Bapak Nashrullah, S.Pd selaku Guru Kelas V SD Inpres Perumnas Antang II/I Kota Makassar yang telah memberikan waktu kepada penulis untuk mengumpulkan data serta membantu dalam penelitian ini.

11. Teman-teman mahasiswa mahasiswa angkatan 2014 PGSD khususnya yang selalu memberi motivasi dalam menyelesaikan skripsi ini.

Terkhusus kedua orang tua tercinta Bapak Syaharuddin Yahya dan Ibu Suryani, saudara-saudara beserta keluarga yang senantiasa memberikan doa dan restunya sehingga penulis dapat menyelesaikan pendidikan sarjana (S1).

Penulis menyadari sepenuhnya bahwa skripsi ini masih kurang sempurna sehingga kepada pembaca, kiranya dapat memberikan saran yang bersifat membangun agar kekurangan-kekurangan yang ada dapat diperbaiki.

Akhirnya penulis berharap semoga skripsi ini dapat bermanfaat dalam pengembangan kualitas pendidikan di masa yang akan datang.

Makasssar, 27 Agustus 2018

Penulis 
HALAMAN SAMPUL i

HALAMAN JUDUL ii

HALAMAN PENGESAHAN iii

PERNYATAAN KEASLIAN SKRIPSI iv

MOTTO DAN PERSEMBAHAN V v

ABSTRAK vi

KATA PENGANTAR viii

DAFTAR ISI $\quad x$

DAFTAR TABEL X xii

DAFTAR GAMBAR X xiii

DAFTAR LAMPIRAN xiv

I. PENDAHULUAN 1

A. Latar Belakang Masalah 1

B. Rumusan Masalah 8

C. Tujuan Penelitian 8

D. Manfaat Penelitian 8

II. KAJIAN PUSTAKA, KERANGKA PIKIR, HIPOTESIS TINDAKAN10

A. Kajian Pustaka 10

1. Pengertian Belajar 10

2. Pengertian Hasil Belajar 11

3. Hakikat Pembelajaran Matematika di Sekolah Dasar 12

4. Model Pembelajaran 14

5. Model Pembelajaran Auditory, Intelectually, Repetition (AIR) 15

6. Model Pembelajaran Auditory, Intelectually, Repetition (AIR) terhadap Pembelajaran Matematika 22

B. Kerangka Pikir 23

C. Hipotesis Tindakan 25 
A. Pendekatan dan Jenis Penelitian 26

B. Fokus Penelitian 27

C. Setting dan Subjek Penelitian 27

D. Rancangan Tindakan 28

E. Teknik Pengumpulan Data dan Instrumen Penelitian 32

F. Teknik Analisis Data 34

G. Indikator Keberhasilan 36

IV. HASIL PENELITIAN DAN PEMBAHASAN 37

A. Hasil Penelitian 37

1. Paparan Data Siklus I 37

2. Paparan Data Siklus II 53

B. Pembahasan 67

$\begin{array}{ll}\text { V. PENUTUP } & 71\end{array}$

A. Kesimpulan 71

B. Saran 71

DAFTAR PUSTAKA $\quad 72$

$\begin{array}{lr}\text { LAMPIRAN } & \mathbf{7 3}\end{array}$

$\begin{array}{ll}\text { RIWAYAT HIDUP } & 147\end{array}$ 


\section{DAFTAR TABEL}

Tabel

Judul

Halaman

2.1 Sintaks Model Pembelajaran Auditory, Intellectually, Repetition (AIR)

3.1 Subjek Penelitian 28

3.2 Kriteria Hasil Belajar 36

3.3 Kriteria Tingkat Keberhasilan 36

4.1 Hasil Observasi Kegiatan Mengajar Guru 49

4.2 Hasil Observasi Kegiatan Belajar Siswa 50

4.3 Distribusi Frekuensi Dan Persentase Hasil Belajar Siswa Siklus I 51

4.4 Hasil Observasi Kegiatan Mengajar Guru 63

4.5 Hasil Observasi Kegiatan Belajar Siswa 64

4.6 Distribusi Frekuensi Dan Persentase Hasil Belajar Siswa Siklus I 65

4.7 Tabel Keberhasilan Siklus I dan Siklus II 67 


\section{DAFTAR GAMBAR}

Gambar

2.1 Kerangka Pikir

3.1 Alur penelitian
Judul

Halaman

24

32 


\section{DAFTAR LAMPIRAN}

Lampiran

Judul

Halaman

1. Rencana Pelaksanaan Pembelajaran (RPP) Siklus I Pertemuan Ke-1

2. Lembar Kerja Siswa (LKS) Siklus I Pertemuan Ke-1 77

3. Perolehan Skor LKS Siklus I Pertemuan Ke-1 79

4. Hasil Observasi Kegiatan Mengajar Guru Siklus I Pertemuan

$\mathrm{Ke}-1$

80

5. Hasil Observasi Kegiatan Belajar Siswa Siklus I Pertemuan

$\mathrm{Ke}-1$

6. Rencana Pelaksanaan Pembelajaran (RPP) Siklus I Pertemuan Ke-2

7. Lembar Kerja Siswa (LKS) Siklus I Pertemuan Ke-2 87

8. Perolehan Skor LKS Siklus I Pertemuan Ke-2

9. Hasil Observasi Kegiatan Mengajar Guru Siklus I Pertemuan $\mathrm{Ke}-2$

10. Hasil Observasi Kegiatan Belajar Siswa Siklus I Pertemuan

$\mathrm{Ke}-2$

11. Rencana Pelaksanaan Pembelajaran (RPP) Siklus I Pertemuan Ke-3

12. Hasil Observasi Kegiatan Mengajar Guru Siklus I Pertemuan $\mathrm{Ke}-3$

13. Hasil Observasi Kegiatan Belajar Siswa Siklus I Pertemuan $\mathrm{Ke}-3$

14. Evaluasi (Tes Formatif) Siklus I

15. Perolehan Skor Evaluasi (Tes Formatif) Siklus I

16. Rencana Pelaksanaan Pembelajaran (RPP) Siklus II Pertemuan Ke-1

17. Lembar Kerja Siswa (LKS) Siklus II Pertemuan Ke-1 108

18. Perolehan Skor LKS Siklus II Pertemuan Ke-1 $110 \backslash$ 
19. Hasil Observasi Kegiatan Mengajar Guru Siklus II Pertemuan Ke-1

20. Hasil Observasi Kegiatan Belajar Siswa Siklus II Pertemuan $\mathrm{Ke}-1$

21. Rencana Pelaksanaan Pembelajaran (RPP) Siklus II Pertemuan Ke-2

22. Lembar Kerja Siswa (LKS) Siklus II Pertemuan Ke-2

23. Perolehan Skor LKS Siklus II Pertemuan Ke-2

24. Hasil Observasi Kegiatan Mengajar Guru Siklus II Pertemuan $\mathrm{Ke}-2$

25. Hasil Observasi Kegiatan Belajar Siswa Siklus II Pertemuan $\mathrm{Ke}-2$

26. Rencana Pelaksanaan Pembelajaran (RPP) Siklus II Pertemuan Ke-3

27. Hasil Observasi Kegiatan Mengajar Guru Siklus II Pertemuan $\mathrm{Ke}-3$

28. Hasil Observasi Kegiatan Belajar Siswa Siklus II Pertemuan $\mathrm{Ke}-3$

29. Evaluasi (Tes Formatif) Siklus II 132

30. Kisi-Kisi Soal Matematika 134

31. Perolehan Skor Evaluasi (Tes Formatif) Siklus II 135

32. Rekapitulasi Perolehan Nilai Matematika 137

33. Foto Pelaksanaan Penelitian 139

34. Surat Izin Penelitian 143

35. Surat Keterangan Penelitian 146 


\section{BAB I}

\section{PENDAHULUAN}

\section{A. Latar Belakang Masalah}

Pendidikan merupakan upaya yang dapat mempercepat pengembangan potensi manusia untuk mampu mengemban tugas yang dibebankan padanya. Pendidikan dapat diperoleh secara formal ataupun informal. Pendidikan yang diadakan pada lingkup sekolah merupakan pendidikan formal, melalui pendidikan inilah berbagai aspek kehidupan dikembangkan melalui proses belajar dan pembelajaran. Pendidikan terdiri atas beberapa komponen, yang masing-masing komponen mempunyai hubungan yang saling kait mengait, tidak dapat dipisahkan antara satu dengan yang lain serta saling mempengaruhi yang semuanya diarahkan sebagai upaya untuk mencapai tujuan yang telah ditetapkan. Komponen pendidikan terdiri atas beberapa elemen yaitu siswa, kepala sekolah, guru, staf tata usaha, kurikulum, fasilitas pendidikan, orang tua siswa dan masyarakat.

Pendidikan juga dapat didefenisikan sebagai proses pemberian bantuan atau tuntunan kepada siswa untuk mencapai tingkat perkembangan secara intelektual dan emosional yang diwujudkan dengan adanya proses belajar mengajar. Proses pembelajaran pada hakikatnya diarahkan untuk membelajarkan siswa agar dapat mencapai tujuan yang telah ditentukan. Ini artinya siswa harus dijadikan sebagai pusat segala kegiatan sehingga dalam perencanaan dan mendesain pembelajaran harus disesuaikan dengan kondisi siswa yang bersangkutan. 
Undang-Undang Nomor 20 tahun 2003 tentang Sistem Pendidikan Nasional pasal 1 Butir (1) dijelaskan bahwa:

Tujuan pendidikan nasional berfungsi mengembangkan kemampuan membentuk watak dan membentuk peradaban bangsa yang bermartabat dalam rangka mencerdaskan kehidupan bangsa, bertujuan untuk berkembangnya potensi peserta didik agar menjadi manusia yang beriman dan bertakwa terhadap Tuhan Yang Maha Esa, dan menjadi warga negara yang demokratis serta bertanggung jawab.

Proses pendidikan di sekolah dasar merupakan landasan paling mendasar untuk terselenggaranya kegiatan belajar mengajar pada jenjang yang lebih tinggi yaitu pendidikan menengah dan jenjang pendidikan tinggi. Ini berarti berhasil tidaknya pencapaian tujuan pendidikan banyak tergantung kepada bagaimana proses belajar yang dialami oleh siswa pada jenjang pendidikan sekolah dasar.

Pelaksanaan proses pendidikan di sekolah dasar terdiri dari beberapa mata pelajaran salah satunya adalah mata pelajaran matematika. Matematika merupakan salah satu pembelajaran yang ada pada semua jenjang pendidikan mulai dari sekolah dasar sampai perguruan tinggi. Pembelajaran matematika perlu diberikan kepada siswa mulai dari sekolah dasar untuk membekali kemampuan berpikir kritis, logis, sistematis dalam menganalisis data, kreatif dalam berpikir. Hal ini sejalan dengan pendapat Susanto (2013:183) yang mengatakan bahwa "karena dengan belajar matematika, kita akan belajar bernalar secara kritis, kreatif dan aktif'. Belajar matematika merupakan suatu syarat yang perlu dilalui untuk melanjutkan pendidikan ke jenjang berikutnya. Pelajaran matematika berisi ideide abstrak berupa simbol-simbol sehingga konsep-konsepnya harus dipahami terlebih dahulu sebelum memanipulasi simbol-simbol tersebut. 
Pembelajaran matematika adalah suatu proses belajar mengajar yang dibangun oleh guru untuk mengembangkan kreativitas berpikir siswa yang dapat meningkatkan kemampuan berpikir siswa serta dapat meningkatkan kemampuan mengkonstruksi pengetahuan baru sebagai upaya meningkatkan penguasaan yang baik terhadap materi matematika. Susanto (2013:189) mengatakan bahwa secara umum, tujuan pembelajaran matematika di sekolah dasar adalah agar siswa mampu dan terampil dalam menggunakan matematika. Dalam proses pembelajaran matematika, baik guru maupun siswa bersama-sama menjadi pelaku terlaksananya tujuan pembelajaran.

Pelajaran matematika merupakan pelajaran yang memerlukan pemahaman dan pengertian dengan konsep matematika itu sendiri. Pada saat sekarang, permasalahan yang terjadi adalah kurangnya pemahaman konsep matematika yang terjadi setiap tahunnya. Jika siswa tidak paham konsep matematika maka untuk melanjutkan pelajaran berikutnya akan makin sulit dan kecintaan siswa kepada pelajaran matematika akan memudar bahkan hilang. Dikarenakan hal tersebut, semua siswa tidak lagi memfavoritkan dan menyukai pelajaran ini karena tidak sedikit siswa yang beranggapan matematika adalah pelajaran yang menakutkan, sangat sulit dipahami dan sangat membosankan. Baru beberapa puluh menit proses belajar mengajar matematika, para siswa telah merasa bosan dan konsentrasi pun sudah mulai berkurang. Sehingga kurang dari setengah materi yang disampaikan guru yang diserap oleh para siswa. Hal ini menyebabkan pemahaman konsep yang berkurang setiap pertemuan matematika. 
Untuk itu perlu ditingkatkan pemahaman konsep matematika sehingga siswa tertarik, menyukai dan memfavoritkan pelajaran matematika.

Kurangnya pemahaman konsep matematika atau rendahnya pemahaman konsep matematika menyebabkan minat belajar siswa juga sangat rendah dalam pelajaran matematika. Kenyataannya, hasil penelitian masih menunjukkan bahwa proses pembelajaran matematika di sekolah dasar masih belum menunjukkan hasil yang memuaskan.

Rendahnya prestasi belajar matematika disebabkan dari faktor guru dan siswa. Menurut Susanto (2013:191), masalah yang berasal dari guru adalah masalah klasik tentang penerapan model pembelajaran matematika yang masih terpusat pada guru (teacher oriented) sementara siswa cenderung pasif.

Pada saat melakukan observasi tanggal 25 Mei 2018 di SD Inpres Perumnas Antang II/I Kota Makassar diketahui terdapat siswa yang memperoleh nilai dibawah kriteria ketuntasan minimal (KKM) yang berjumlah 13 orang siswa dari 30 orang siswa (43\%) yang memperoleh nilai diatas standar. Sedangkan 17 orang siswa (57\%) memperoleh nilai dibawah KKM. Adapun KKM yang ditentukan di SD Inpres Perumnas Antang II/I untuk mata pelajaran matematika yaitu 70.

Berdasarkan hasil observasi tanggal 25 Mei 2018 yang dilakukan di SD Inpres Perumnas Antang II/I khususnya pada kelas V ditemukan beberapa masalah diantaranya: guru kurang menggunakan model pembelajaran sehingga dalam proses pembelajaran matematika guru masih mendominasi, hal ini membuat siswa merasa bosan dalam mengikuti pembelajaran dan ketika guru bertanya siswa hanya diam tidak menjawab pertanyaan, kurang mengaktifkan 
siswa dalam proses pembelajaran membuat siswa pasif dan hanya sebagai pendengar apa yang disampaikan oleh guru sehingga memperlihatkan siswa acuh terhadap penjelasan guru, kurangnya interaksi antara siswa ketika diberikan tugas kelompok karena guru jarang menggunakan model yang bervariasi, siswa sering lupa terhadap materi yang diajarkan guru karena proses pembelajaran cenderung monoton. Kondisi tersebut menjadikan siswa kurang antusias terhadap materi yang diajarkan, siswa ada yang bicara dan bermain sendiri saat guru menerangkan pelajaran/materi akibatnya banyak siswa yang kurang paham terhadap materi yang diajarkan.

Model pembelajaran yang masih terpusat pada guru menjadi penyebab kurang aktif dan kurangnya kreativitas siswa dalam pembelajaran matematika, model ini kurang memberikan kesempatan kepada siswa untuk terlibat dalam proses pembelajaran yang ada. Jika kondisi yang sama terjadi secara terus menerus maka akan berdampak pada rendahnya hasil belajar siswa yang ditandai dengan bosannya siswa terhadap pelajaran matematika.

Penggunaan model pembelajaran yang tepat dalam proses pembelajaran matematika dapat membantu siswa memperoleh pengetahuan dengan lebih baik. Model pembelajaran yang dapat diterapkan oleh guru dalam mengajar harus melibatkan siswa secara aktif serta membantu siswa dalam memahami materi pelajaran secara lebih mendalam. Pemilihan model yang baik dapat dijadikan alternatif untuk membantu siswa memperoleh pengetahuan yang baik tanpa harus merasa bosan sehingga hasil belajar siswa dapat ditingkatkan serta membantu guru mencapai tujuan pembelajaran. 
Berdasarkan permasalahan tersebut, maka calon peneliti menawarkan salah satu model pembelajaran yakni model pembelajaran Auditory, Intellectually, Repetition (AIR). Model pembelajaran ini dipilih sebagai salah satu upaya untuk meningkatkan hasil belajar matematika. Model pembelajaran AIR merupakan singkatan dari Auditory, Intellectually, Repetition. Dengan model pembelajaran AIR siswa dapat ikut aktif dalam proses pembelajaran sehingga tercipta proses pembelajaran yang menyenangkan dan tidak hanya berpusat pada guru. Selain itu model pembelajaran AIR menerapkan jika belajar juga harus dengan pengulangan (repetition). Pengulangan yang bertujuan untuk lebih mengingat kembali materi pelajaran yang telah diajarkan.

Model pembelajaran AIR dari kata auditory menuntut siswa belajar dengan melalui mendengarkan, menyimak, berbicara, presentasi, argumentasi, mengemukakan pendapat dan menanggapi, dari kata intellectually siswa belajar haruslah menggunakan kemampuan berfikir (mind-on), harus dengan konsentrasi pikiran dan berlatih menggunakannya melalui bernalar, menyelidiki, mengidentifikasi, menemukan, mencipta, memecahkan masalah dan menerapkan. Sedangkan repetition adalah pengulangan yang bermakna pendalaman, perluasan, pemantapan dengan cara siswa dilatih melalui pemberian tugas atau kuis. Dengan model pembelajaran ini, proses pembelajaran tidak lagi terpusat pada guru tetapi kepada siswa. Pembelajaran yang diawali dengan presentasi materi oleh guru yang selanjutnya dilakukan pembagian kelompok. Dalam proses pembelajaran, siswa mengerjakan LKS secara bersama-sama dalalam kelompok dan saling membantu. Kegiatan ini memberikan kesempatan bagi siswa untuk saling bertukar pendapat, 
bekerja sama dengan teman, berinteraksi dengan guru. Selanjutnya, siswa diberikan kesempatan mempresentasikan tentang pelajaran yang sudah dipelajari. Peran guru dalam pembelajaran ini yaitu sebagai fasilitator. Proses pembelajaran akan berlangsung secara mandiri yang berpusat pada siswa, sehingga siswa tidak lagi menjadi pendengar saja tetapi siswa juga dapat berbicara mengemukakan pendapatnya. Siswa akan lebih memahami konsep materi pembelajaran, karena guru akan mengulang materi pembelajaran dengan memberikan tugas atau kuis jadi siswa tidak hanya hafal materi tetapi juga dapat lebih termotivasi untuk belajar.

Selain itu berdasarkan penelitian yang dilakukan oleh Khoirun Nesa pada tahun 2016 dengan jenis penelitian eksperimen yang berjudul Keefektifan Model Auditory, Intellectually, Repetition (AIR) terhadap Minat dan Hasil Belajar IPS Siswa Kelas V SD Negeri Pekauman 5 Kota Tegal menunjukkan bahwa hasil belajar IPS siswa meningkat jika diberi pembelajaran dengan model pembelajaran AIR.

Berdasarkan uraian di atas yang terjadi di SD Inpres Perumnas Antang II/I, calon peneliti berinisiatif untuk mengadakan suatu penelitian tindakan kelas pada pembelajaran matematika melalui model pembelajaran AIR dengan judul "Peningkatan Hasil Belajar Matematika Melalui Model Pembelajaran Auditory, Intellectually, Repetition (AIR) Pada Siswa Kelas V SD Inpres Perumnas Antang II/I Kota Makassar". 


\section{B. Rumusan Masalah}

Berdasarkan latar belakang yang telah dikemukakan, maka yang menjadi rumusan masalah dalam penelitian ini adalah bagaimana model pembelajaran Auditory, Intellectually, Repetition (AIR) dapat meningkatkan hasil belajar pada siswa kelas V SD Inpres Perumnas Antang II/I Kota Makassar?

\section{Tujuan Penelitian}

Tujuan penelitian ini adalah untuk mengetahui model pembelajaran Auditory, Intellectually, Repetition (AIR) dapat meningkatkan hasil belajar matematika pada siswa kelas V SD Inpres Perumnas Antang II/I Kota Makassar.

\section{Manfaat Penelitian}

\section{Manfaat Teoretis}

a. Melalui penelitian ini diharapkan dapat memotivasi guru sekolah dasar dalam mengembangkan sistem pembelajaran matematika.

b. Penelitian ini diharapkan dapat menjadi acuan bagi guru untuk meningkatkan kualitas pembelajaran matematika dengan menggunakan model pembelajaran Auditory, Intellectually, Repetition (AIR).

\section{Manfaat Praktis}

a. Bagi sekolah, dapat memberikan masukan untuk sekolah dalam usaha untuk meningkatkan hasil belajar matematika. Serta memberikan motivasi untuk selalu meningkatkan kualitas pembelajaran khususnya pembelajaran matematika 
b. Bagi guru, mendapatkan pengetahuan dalam menggunakan model pembelajaran Auditory, Intellectually, Repetition (AIR) sehingga dapat diterapkan pada materi yang sesuai pada pelajaran matematika.

c. Bagi siswa, mendapat kesempatan dan pengalaman belajar matematika dalam suasana yang menyenangkan, sehingga dapat meningkatkan proses dan hasil belajar matematika.

d. Bagi peneliti lain, secara langsung mendapatkan pengalaman dalam menerapkan model pembelajaran AIR untuk meningkatkan hasil belajar matematika. 


\section{BAB II}

\section{KAJIAN PUSTAKA, KERANGKA PIKIR, DAN HIPOTESIS TINDAKAN}

\section{A. Kajian Pustaka}

\section{Pengertian Belajar}

Menurut E.R. Hilgard (Susanto, 2013:3) "belajar adalah suatu perubahan kegiatan reaksi terhadap lingkungan". Perubahan kegiatan yang dimaksud mencakup pengetahuan, kecakapan, tingkah laku dan ini diperoleh melalui latihan (pengalaman).

Belajar merupakan suatu aktivitas yang akan menghasilkan perubahan. Perubahan ini tidak terjadi dengan sendirinya melainkan melalui proses yang disebut pembelajaran. Seperti yang diungkapkan oleh Hamalik (2005:27), belajar merupakan suatu proses, suatu kegiatan dan bukan suatu hasil atau tujuan. Belajar bukan hanya mengingat, akan tetapi lebih luas dari itu, yakni mengalami. Hal ini didukung oleh gagasan Gagne (Suprijono, 2010:2), yaitu belajar adalah perubahan disposisi atau kemampuan yang dicapai seseorang melalui aktivitas. Perubahan disposisi tersebut bukan diperoleh langsung dari proses pertumbuhan seseorang secara alamiah.

Menurut Amri (2013:24), belajar merupakan suatu proses memperoleh pengetahuan dan pengalaman dalam wujud perubahan tingkah laku dan kemampuan beraksi yang relatif permanen atau menetap karena adanya interaksi individu dengan lingkungannya. W.S Winkel (Susanto, 2013:4), menyatakan bahwa belajar adalah suatu aktivitas mental yang berlangsung 
dalam interaksi perubahan-perubahan dalam pengetahuan, pemahaman dan keterampilan dan nilai sikap yang bersifat konstan dan berbekas.

Dari beberapa pendapat di atas dapat disimpulkan bahwa belajar ialah perubahan kemampuan individu yang merupakan akibat dari suatu proses atau kegiatan menuju perkembangan individu seutuhnya yang menghasilkan perubahan tingkah laku positif dan kemampuan beraksi, baik dalam aspek pengetahuan, afektif, maupun psikomotor.

\section{Pengertian Hasil Belajar}

Secara etimologis, hasil belajar merupakan gabungan dari kata hasil dan belajar. Pengertian hasil dalam Kamus Besar Bahasa Indonesia (2007:391) adalah "sesuatu yang diadakan (dibuat, dijadikan, dsb) oleh usaha". Menurut Gagne, (Anitah dkk, 2009) bahwa belajar adalah suatu proses di mana suatu organisme berubah perilakunya sebagai akibat pengalaman. Dari pengertian belajar tersebut, terdapat tiga atribut pokok (ciri utama) belajar, yaitu: proses, perubahan perilaku, dan pengalaman. Sejalan dengan itu, Travers (Suprijono, 2013:2) mengatakan bahwa "belajar adalah proses menghasilkan penyesuaian tingkah laku”. Dari pendapat para ahli diatas, dapat disimpulkan bahwa belajar adalah proses perubahan tingkah laku seseorang yang menyangkut ranah kognitif, psikomotor dan afektif.

Berdasarkan uraian tentang konsep belajar di atas, dapat dipahami makna hasil belajar. Menurut Sudjana (2008) mengatakan "hasil belajar adalah kemampuan-kemampuan yang dimiliki siswa setelah ia menerima pengalaman belajarnya". Hasil belajar berupa perubahan perilaku atau 
tingkah laku. Seseorang yang mau belajar akan berubah atau bertambah perilakunya, baik yang berupa pengetahuan, keterampilan atau penguasaan nilai-nilai (sikap). Perubahan perilaku sebagai hasil belajar dikelompokkan ke dalam tiga ranah (kawasan), yaitu: pengetahuan (kognitif), keterampilan (psikomotorik) dan penguasaan nilai- nilai atau sikap (afektif). Ketiga ranah tersebut di dalam kurikulum 2004 terkandung dalam rumusan kompetensi. Anitah (2009:15)

Dari pendapat diatas, dapat disimpulkan bahwa hasil belajar adalah perubahan perilaku secara keseluruhan bukan hanya salah satu aspek potensi kemanusiaan.

\section{Hakikat Pembelajaran Matematika di Sekolah Dasar}

\section{a. Pengertian}

Pembelajaran yang diidentikkan dengan kata "mengajar" berasal dari kata dasar "ajar", yang berarti petunjuk yang diberikan kepada orang supaya diketahui. Kata pembelajaran yang semula diambil dari kata "belajar" ditambah awalan "pe” dan akhiran "an" menjadi kata "pembelajaran", diartikan sebagai proses, perbuatan, cara mengajar, atau mengajarkan sehingga anak didik mau belajar. Menurut Undang-Undang Sistem Pendidikan Nasional No.20 Tahun 2003 (Susanto, 2013:19) pembelajaran diartikan sebagai proses interaksi peserta didik dengan pendidik dan sumber belajar pada suatu lingkungan belajar. Jadi, dapat disimpulkan bahwa pembelajaran merupakan komunikasi dua arah yang dilakukan oleh pihak guru sebagai pendidik dan siswa sebagai peserta didik. 
Matematika memiliki bahasan dan aturan yang terdefinisi dengan baik, penalaran yang jelas dan sistematis, struktur atau keterkaitan antar konsep yang kuat. Depdiknas (Susanto, 2013:184)

Mata pelajaran matematika perlu diberikan kepada semua siswa mulai dari sekolah dasar untuk membekali siswa dengan kemampuan berpikir logis, analitis, sistematis, kritis dan kreatif, serta kemampuan bekerjasama.

Berdasarkan pendapat di atas, dapat disimpulkan bahwa pembelajaran matematika adalah proses belajar mengajar yang dibangun oleh guru di dalam membangun kemampuan berpikir siswa serta mengembangkan kreativitas siswa dengan menggunakan penalaran deduktif dalam penyelesaiannya.

\section{b. Tujuan}

Secara umum, tujuan pembelajaran matematika di sekolah dasar menurut Susanto (2013:189) adalah agar siswa mampu dan terampil menggunakan matematika. Selain itu juga, dengan pembelajaran matematika dapat memberikan tekanan penataran nalar dalam penerapan matematika.

Secara khusus, tujuan pembelajaran matematika di sekolah dasar sebagaimana yang disajikan oleh BSNP (2006:148) sebagai berikut: (1) memahami konsep matematika, menjelaskan keterkaitan antarkonsep dan mengaplikasikan konsep atau algoritma, secara luwes, akurat, efisien dan tepat, dalam pemecahan masalah, (2) menggunakan penalaran pada pola dan sifat, melakukan manipulasi matematika dalam membuat generalisasi, menyusun bukti, atau menjelaskan gagasan dan pernyataan matematika, (3) memecahkan masalah yang meliputi kemampuan memahami masalah, 
merancang model matematika, menyelesaikan model dan menafsirkan solusi yang diperoleh, (4) mengomunikasikan gagasan dengan simbol, tabel, diagram, atau media lain untuk memperjelas keadaan atau masalah, (5) memiliki sikap menghargai kegunaan matematika dalam kehidupan, yaitu memiliki rasa ingin tahu, perhatian dan minat dalam mempelajari matematika serta sikap ulet dan percaya diri dalam pemecahan masalah.

Untuk mencapai tujuan pembelajaran matematika tersebut, guru hendaknya menciptakan kondisi dan situasi pembelajaran yang memungkinkan siswa aktif membentuk, menemukan dan mengembangkan pengetahuannya sehingga menghasilkan pembelajaran yang sesuai dengan tujuan tersebut.

\section{c. Ruang Lingkup}

Menurut BSNP (2006:11), "Mata pelajaran matematika pada satuan pendidikan sekolah dasar meliputi aspek-aspek sebagai berikut: (1) bilangan, (2) geometri dan pengukuran, (3) pengolahan data". Aspek-aspek tersebut dirancang sesuai dengan kemampuan, kebutuhan dan karakterisktik siswa sekolah dasar agar dapat berkembang secara optimal. Materi-materi dalam pembelajaran matematika, guru mampu mengarahkan siswa untuk menggunakan konsep yang diberikan dalam kehidupan sehari-hari dengan mengaplikasikan konsep tersebut.

\section{Model Pembelajaran}

Model pembelajaran merupakan salah satu pendekatan yang digunakan oleh guru untuk mencapai keberhasilan dalam kegiatan pembelajaran. 
Menurut Komalasari (2010:57) model pembelajaran pada dasarnya merupakan bentuk pembelajaran yang tergambar dari awal sampai akhir yang disajikan secara khas oleh guru. Soekamto (Trianto, 2009:22) mengungkapkan bahwa model pembelajaran adalah kerangka konseptual yang melukiskan prosedur yang sistematis dalam mengorganisasikan pengalaman belajar untuk mencapai tujuan belajar tertentu dan berfungsi sebagai pedoman bagi para perancang pembelajaran dan para pengajar dalam merencanakan dan melaksanakan aktivitas belajar mengajar. Sedangkan menurut Suprihatiningrum (2013:145), model pembelajaran merupakan suatu rancangan yang di dalamnya menggambarkan sebuah proses pembelajaran yang dapat dilaksanakan oleh guru dalam mentransfer pengetahuan maupun nilai-nilai kepada siswa.

Menurut Jusmawati (2015: 31) agar pembelajaran berjalan secara optimal, perlu suatu kondisi belajar yang memungkinkan siswa lebih aktif dalam meningkatkan eksplorasi investigasi, mengemukakan pendapat, saling membantu dan berbagi pendapat dengan teman untuk menyelesaikan masalah yang diberikan di dalam pembelajaran. Salah satu cara untuk mengatasi hal diatas dan juga Perbedaan individual siswa adalah belajar dengan kelompokkelompok kecil yang disebut pembelajaran kooperatif.

Dari beberapa pendapat diatas dapat disimpulkan bahwa model pembelajaran adalah kerangka konseptual mengenai prosedur pembelajaran yang tergambar secara sistematis sebagai pedoman dalam merencanakan dan melaksanakan pembelajaran yang dapat dilaksanakan oleh guru dalam mentransfer pengetahuan maupun nilai-nilai kepada siswa.

5. Model Pembelajaran Auditory Intellectually Repetition (AIR)

a. Pengertian Model Pembelajaran AIR 
Huda (2003:289) berpendapat bahwa model pembelajaran Auditory, Intellectually, Repetition (AIR) ini mirip dengan Somatic, Auditory, Visualitation, Intelectually (SAVI) dan Visualitation, Auditory, Kinestetic (VAK). Perbedaannya hanya terletak pada repetisi, yaitu pengulangan yang 
bermakna pendalaman, perluasan, pemantapan dengan cara siswa dilatih melalui pemberian tugas atau kuis.

Menurut Suherman (Humaira, 2012:18) AIR adalah singkatan dari Auditory, Intellectually and Repetition. Pembelajaran seperti ini menganggap bahwa akan efektif apabila memperhatikan tiga hal tersebut. Auditory yang berarti bahwa indera telinga digunakan dalam belajar dengan cara mendengarkan, menyimak, berbicara, persentasi, argumentasi, mengemukakan pendapat dan menanggapi. Intellectually berpikir yang berarti bahwa kemampuan berpikir perlu dilatih melalui latihan bernalar, mencipta, memecahkan masalah, mengkonstruksi dan menerapkan. Repetition yang berarti pengulangan, agar pemahaman lebih mendalam dan lebih luas, siswa perlu dilatih melalui pengerjaan soal, pemberian tugas atau kuis.

Berikut adalah penjelasan dari masing-masing tahap dalam model pembelajaran AIR:

\section{1) Auditory}

Auditory berarti belajar dengan melibatkan pendengaran. Mendengar merupakan salah satu aktivitas belajar, karena tidak mungkin informasi yang disampaikan secara lisan oleh guru dapat diterima dengan baik oleh siswa jika tidak melibatkan indera telinganya untuk mendengar. Sarbana (Humaira, 2012:19) mengartikan auditory sebagai salah satu modalitas belajar, yaitu bagaimana kita menyerap informasi saat berkomunikasi ataupun belajar dengan cara mendengarkan. Sedangkan Meier (Huda, 2003:289) pernah menyatakan bahwa pikiran auditoris lebih kuat daripada yang kita sadari. 
Telinga terus menerus menangkap dan menyimpan informasi auditoris, bahkan tanpa disadari.

Ketika telinga menangkap dan menyimpan informasi, beberapa area penting di otak menjadi aktif. Dalam hal ini guru diharapkan mampu memberikan bimbingan pada siswa agar pemanfaatan indera telinga dalam pembelajaran dapat berkembang secara optimal sehinga interkoneksi antara telinga dan otak bisa dimanfaatkan secara maksimal.

\section{2) Intellectually}

Menurut Meier (Huda, 2003:290), Intellectually berarti menunjukkan apa yang dilakukan siswa dalam pikiran mereka secara internal ketika mereka menggunakan kecerdasan untuk merenungkan suatu pengalaman, menciptakan hubungan, makna, rencana dan nilai dari pengalaman tersebut.

Belajar intelektual adalah bagian untuk merenung, menciptakan, memecahkan masalah dan membangun makna. Menurut Meier (Huda, 2003:91) aspek intelektual dalam belajar akan terlatih jika guru mengajak siswa terlibat dalam aktivitas aktivitas intelektual, seperti: (1) Memecahkan masalah; (2) menganalisis pengalaman; (3) mengerjakan perencanaan strategis; (4) melahirkan gagasan kreatif; (5) mencari dan menyaring informasi; (6) merumuskan pertanyaan; (7) menciptakan model mental; (8) menerapkan gagasan baru pada pekerjaan; (9) menciptakan makna pribadi dan (10) meramalkan implikasi suatu gagasan. 


\section{3) Repetition}

Repetition, yaitu pengulangan yang bermakna pendalaman, perluasan, pemantapan siswa dengan cara memberinya tugas atau kuis. Bila guru menjelaskan suatu unit pelajaran, itu perlu diulang-ulang. Karena ingatan siswa tidak selalu tetap dan mudah lupa, maka perlu dibantu dengan mengulangi pelajaran yang sedang dijelaskan. Huda (2003:292) mengungkapkan pelajaran yang diulang akan memberikan tanggapan yang jelas dan tidak mudah dilupakan, sehingga dapat digunakan oleh siswa untuk memecahkan masalah. Suherman dan Winataputra (Humaira, 2012:21) menjelaskan bahwa pengulangan yang akan memberikan dampak positif adalah pengulangan yang tidak membosankan dan disajikan dalam metode yang menarik.

Ada beberapa jenis kegiatan yang dilakukan dalam model pembelajaran Auditory, Intellectually, Repetition (AIR), yaitu sebagai berikut.

a) Membentuk pembelajaran kelompok dan diskusi. Pada kegiatan ini siswa dapat saling menukar informasi yang didapatnya dan siswa dapat mengeluarkan ide mereka secara verbal atau guru mengajak siswa membicarakan tentang apa yang dipelajari, diantaranya menterjemahkan pengalaman mereka dengan suara, mengajak mereka berbicara saat memecahkan masalah, membuat model, mengumpulkan informasi dan sebagainya sehingga mereka akan melahirkan gagasan yang kreatif.

b) Memecahkan masalah. Pada kegiatan ini ada beberapa hal yang dilakukan siswa dalam mengerjakan perencanaan strategis untuk menyelesaikan soal, 
yaitu mencari dan menyaring informasi, merumuskan pertanyaan, membuat model dan menyelesaikan soal dengan menerapkan seluruh gagasan pada pekerjaan.

c) Melakukan presentasi. Pada kegiatan ini siswa diminta untuk mempresentasikan hasil pekerjaan yang telah mereka diskusikan tadi. Siswa diharapkan dapat memikirkan bagaimana cara mereka untuk menerapkan informasi dalam presentasi tersebut sehingga mereka dapat meningkatkan kemampuan mereka dalam memecahkan masalah. Kemudian siswa yang lain menanggapi hasil diskusi kelompok lain sehingga terjadi diskusi antar seluruh siswa dan guru akan membantu jika siswa mengalami kesulitan.

d) Melakukan repetisi. Pada kegiatan ini guru melakukan repetisi kepada seluruh siswa tetapi bukan secara berkelompok melainkan secara individu. Repetisi yaitu pengulangan yang bermakna pendalaman, perluasan, pemantapan dengan cara siswa dilatih melalui pemberian tugas atau kuis.

b. Langkah-langkah Model Pembelajaran Auditory, Intellectually, Repetition (AIR)

Adapun Langkah-langkah pembelajaran Auditory, Intellectually, Repetition (AIR) menurut Meirawati (Humaira, 2012: 21-22), yaitu:

\section{Tahap Auditory}

1) Guru membagi siswa menjadi beberapa kelompok kecil.

2) Guru membagikan Lembar Kerja Siswa (LKS) kepada siswa untuk dikerjakan secara kelompok. 
3) Guru memberi kesempatan kepada siswa untuk bertanya mengenai soal LKS yang kurang dipahami.

Tahap Intellectually

1) Guru membimbing kelompok belajar siswa untuk berdiskusi dengan teman dalam satu kelompok sehingga dapat menyelesaikan LKS.

2) Guru memberi kesempatan kepada beberapa kelompok untuk mempresentasikan hasil kerjanya.

3) Guru memberikan kesempatan kepada kelompok lain untuk bertanya dan mengemukakan pendapatnya.

Tahap Repetition

1) Memberikan latihan soal individu kepada siswa.

2) Dengan diarahkan guru, siswa membuat kesimpulan secara lisan tentang materi yang telah dibahas 
Tabel 2.1

Sintaks Model Pembelajaran Auditory, Intellectually, Repetition (AIR)

Sintaks Aktivitas Guru Aktivitas Siswa

\begin{tabular}{llc}
\hline Tahap & 1) Membagi siswa menjadi & 1) Siswa bergabung dengan \\
Auditory & beberapa kelompok & kelompoknya masing- \\
& kecil. & masing. \\
2) & Memberikan LKS & 2) Siswa menerima LKS \\
& kepada siswa untuk & yang diberikan oleh \\
& dikerjakan secara & guru untuk dikerjakan \\
kelompok. & secara kelompok. \\
3) Memberi kesempatan & 3) Siswa bertanya \\
& kepada siswa untuk & mengenai soal LKS \\
bertanya mengenai soal & yang kurang dipahami \\
& LKS yang kurang & kepada guru. \\
& dipahami. &
\end{tabular}

\begin{tabular}{ll}
\hline Tahap & 1) Membimbing kelompok \\
Intellectually & belajar siswa untuk \\
& berdiskusi dengan teman \\
& satu kelompoknya \\
& sehingga dapat \\
menyelesaikan LKS. & 2) Memberi kesempatan \\
kepada beberapa & kelompok untuk \\
mempresentasikan hasil \\
kerjanya. \\
3) Memberikan kesempatan \\
kepada kelompok lain \\
untuk bertanya dan \\
mengemukakan \\
pendapatnya.
\end{tabular}

1) Mengerjakan soal LKS secara berkelompok dengan mencermatik contoh-contoh soal yang telah diberikan.

2) Mempresentasikan hasil kerjanya secara berkelompok yang telah selesai

3) Siswa dari kelompok lain bertanya dan mengungkapkan pendapatnya sedangkan kelompok yang mempresentasikan menjawab dan mempertahankan hasil kerjanya.

\begin{tabular}{ll}
\hline Tahap & 1) Memberikan latihan soal \\
Repetition & individu kepada siswa. \\
& 2) Dengan diarahkan guru, \\
& siswa membuat \\
& kesimpulan secara lisan \\
& tentang materi yang telah \\
& dibahas.
\end{tabular}

1) Mengerjakan soal latihan yang diberikan oleh guru secara individu.

2) Menyimpulkan secara lisan tentang materi yang telah dibahas. 


\section{c. Kelebihan Model Pembelajaran Auditory, Intellectually, Repetition (AIR)}

Setiap model pembelajaran memiliki kelebihan seperti halnya pada model pembelajaran Auditory, Intellectually, Repetition (AIR). Adapun yang menjadi kelebihan dari model pembelajaran AIR adalah sebagai berikut.

1) Melatih pendengaran dan keberanian siswa untuk mengungkapkan pendapat (Auditory).

2) Melatih siswa untuk memecahkan masalah secara kreatif (Intellectually).

3) Melatih siswa untuk mengingat kembali tentang materi yang telah dipelajari (Repetition).

4) Siswa menjadi lebih aktif dan kreatif.

6. Model Pembelajaran Auditory, Intellectually, Repetition (AIR) terhadap Pembelajaran Matematika

Model pembelajaran Auditory, Intellectually, Repetition (AIR) adalah strategi pembelajaran yang efektif dengan memperhatikan tiga hal yaitu:

a. Auditory, yang berarti indra telinga digunakan dalam belajar dengan cara mendengarkan, menyimak, berbicara, mengemukakan pendapat, menanggapi, presentasi dan argumentasi.

b. Intellectually, yang berarti kemampuan berfikir perlu dilatih melalui latihan bernalar, mengkonstruksi, menerapkan gagasan, mengajukan pertanyaan dan memecahkan masalah.

c. Repetition (pengulangan), yang berarti pemberian kuis, tugas pekerjaan rumah agar pemahaman siswa lebih luas dan mendalam. 
Jadi pada model pembelajaran ini diikutsertakan peran siswa dalam belajar terutama pada repetition karena pada bagian ini siswa akan diberi tugas, kuis, dan pekerjaan rumah. Saat pemberian tugas yang berulang-ulang pemahaman konsep siswa akan meningkat. Jika mereka telah terbiasa dengan mengerjakan soal-soal dalam matematika maka otak siswa otomatis akan ikut terbiasa dalam memikirkan jawaban dari persoalan yang ada.

\section{B. Kerangka Pikir}

Berdasarkan pengamatan di kelas V SD Inpres Perumnas Antang II/I Kota Makassar ditemukan masalah rendahnya hasil belajar siswa pada mata pelajaran Matematika. Permasalahan yang nampak tentunya tidak lepas dari beberapa penyebab. Penyebab tersebut antara lain pembelajaran masih berpusat pada guru, kurang menggunakan model pembelajaran yang bervariasi sehingga membuat siswa kurang tertarik dan temotivasi dalam belajar.

Permasalahan tersebut berdampak pada proses belajar siswa itu sendiri dalam mengikuti mata pelajaran matematika. Siswa cenderung masih bergantung pada guru. Dari fakta tersebut mendorong peneliti untuk menemukan suatu alternatif, yaitu perlu adanya perbaikan dalam proses pembelajaran yang bertujuan untuk meningkatkan hasil belajar matematika. Salah satunya dengan menerapkan model pembelajaran Auditory, Intellectually, Repetition (AIR) pada proses pembelajaran Matematika. Adapun tahapan-tahapan dalam model pembelajaran AIR dari auditory yaitu mendengarkan dan melihat penjelasan guru, dalam diskusi kelompok, mengemukakan pendapat dengan intellectualy, maka sebagai penutup 
yaitu sebuah pengulangan atau repetition, dimana peserta didik diberikan sebuah tugas atau kuis yang dikerjakan secara individu guna meningkatkan hasil belajar.

Kerangka pikir mengenai peningkatan hasil belajar matematika menggunakan model pembelajaran AIR digambarkan sebagai berikut.

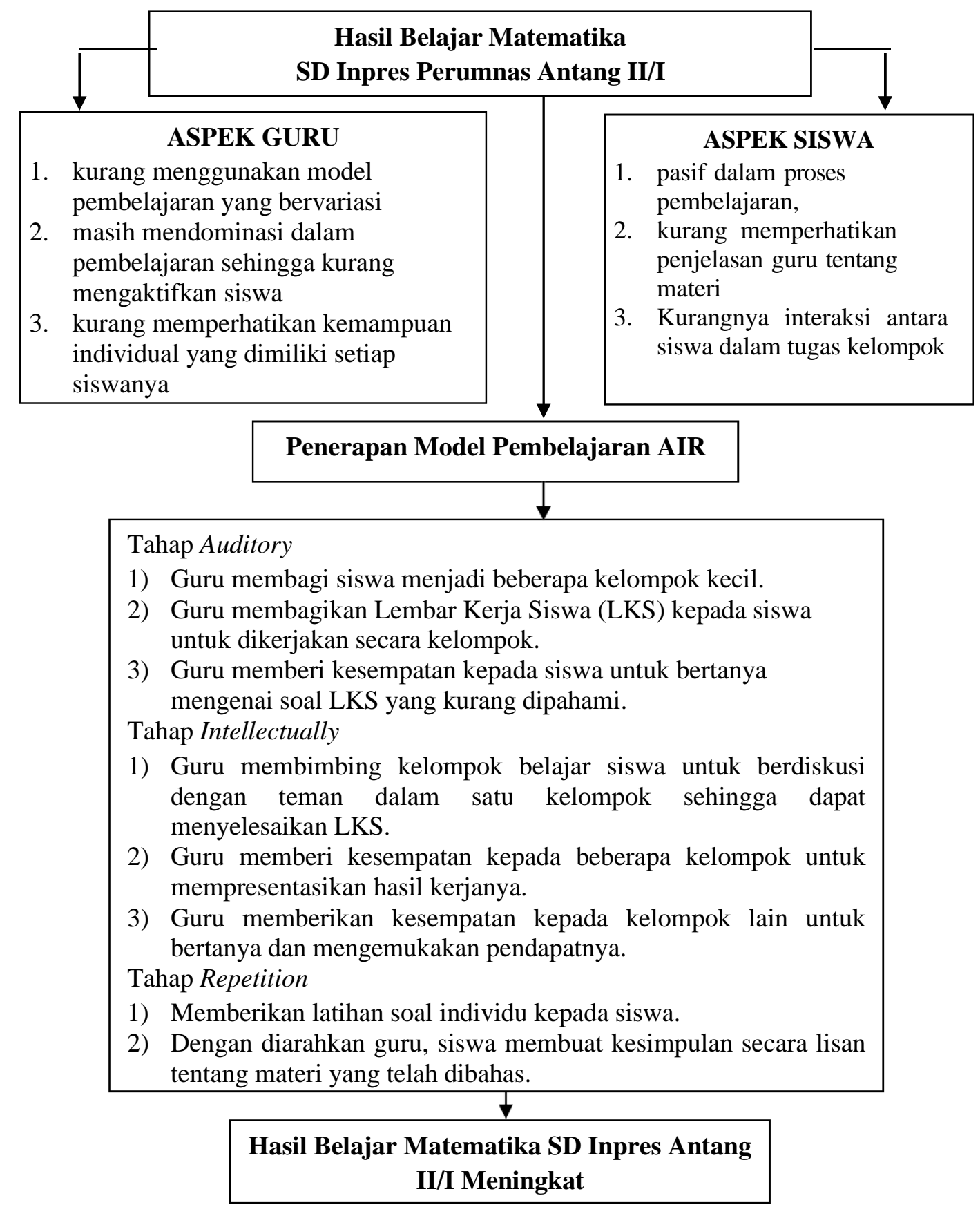

Gambar 2.1. Kerangka Pikir 


\section{Hipotesis Tindakan}

Berdasarkan pembahasan dan kerangka pikir diatas, maka hipotesis tindakan dalam peneletian ini adalah jika model pembelajaran Auditory, Intellectually, Repetition (AIR) diterapkan maka hasil belajar Matematika siswa kelas V SD Inpres Perumnas Antang II/I Kota Makassar akan meningkat. 


\section{BAB III}

\section{METODE PENELITIAN}

\section{A. Pendekatan dan Jenis Penelitian}

\section{Pendekatan Penelitian}

Penelitian ini menggunakan pendekatan mix method, yaitu pendekatan yang dilakukan dengan memberikan sajian data secara kualitatif dan kuantitatif. Pendekatan kualitatif menggunakan analisis data secara induktif artinya data-data yang terkumpul dianalisis untuk menarik suatu kesimpulan. Sedangkan pendekatan kuantitatif banyak dituntut menggunakan angka, mulai dari pengumpulan data serta hasilnya. (Arikunto, 2011:12),

\section{Jenis Penelitian}

Jenis penelitian ini adalah Penelitian Tindakan Kelas (Classroom Action Research), yaitu suatu pencermatan terhadap kegiatan belajar berupa sebuah tindakan yang sengaja ditimbulkan dan terjadi dalam sebuah kelas secara bersama dan dilaksanakan berdasarkan tahapan-tahapan PTK yaitu perencanaan, pelaksanaan, observasi dan refleksi. (Arikunto, 2009:3).

Karakteristik yang khas dari PTK yakni tindakan-tindakan (aksi) yang berulang-ulang untuk memperbaiki proses belajar mengajar di kelas. Menurut Arikunto (2011:3) mengemukakan pengertian PTK adalah "suatu pencermatan terhadap kegiatan belajar berupa sebuah tindakan, yang sengaja dimunculkan dan terjadi dalam sebuah kelas secara bersama-sama”. 


\section{B. Fokus Penelitian}

Fokus dalam penelitian tindakan kelas ini yaitu:

1. Faktor siswa, yaitu dengan melihat hasil belajar siswa terhadap mata pelajaran matematika berada dalam kategori yang diharapkan.

2. Faktor guru, yaitu dengan memperhatikan bagaimana persiapan, kesesuaian perencanaan dan implementasi dalam pembelajaran matematika dengan penerapan model pembelajaran Auditory, Intellectually, Repetition (AIR).

3. Faktor sumber belajar. yaitu memperhatikan sumber belajar yang digunakan apakah sudah sesuai dengan tujuan yang hendak dicapai. Demikian pula latihan-latihan yang diberikan apakah sesuai dengan tingkat kemampuan siswa serta tujuan yang telah direncanakan.

\section{Setting dan Subjek Penelitian}

\section{Setting Penelitian}

Penelitian ini dilaksanakan di kelas V SD Inpres Perumnas Antang II/I Kota Makassar. Keadaan kelas cukup baik untuk kegiatan belajar mengajar karena ditunjang oleh sarana yang memadai, kebersihan kelas terjaga sehingga memungkinkan siswa belajar dengan nyaman. Penelitian ini direncanakan pada semester ganjil tahun ajaran 2018/2019. Alasan memilih sekolah ini adalah :

a. Rendahnya hasil belajar matematika siswa kelas V SD Inpres Perumnas Antang II/I.

b. Lokasi sekolah mudah dijangkau oleh peneliti. 


\section{Subjek Penelitian}

Dalam penelitian ini yang menjadi subjek adalah guru dan seluruh siswa kelas V SD Inpres Perumnas Antang II/I Kota Makassar serta kejadiankejadian yang terjadi selama proses pembelajaran matematika berlangsung, berupa model, suasana belajar dan kondisi siswa. Adapun jumlah siswa kelas V SD Inpres Perumnas Antang II/I yang dijadikan subjek dalam penelitian ini yaitu 28 orang siswa dengan rincian sebagai berikut:

Tabel 3.1 Subjek Penelitian

\begin{tabular}{ccccc}
\hline \multirow{2}{*}{ Kelas } & \multicolumn{3}{c}{ Jenis Kelamin } & \multirow{2}{*}{ Jumlah } \\
& L & P & \\
\hline $\mathrm{V}$ & 11 & 19 & 30 \\
\hline & Jumlah & & 30 \\
\hline
\end{tabular}

Sumber : TU SD Inpres Perumnas Antang II/I

\section{Rancangan Tindakan}

Penelitian ini menggunakan rencana penelitian tindakan kelas (Action research), yaitu rencana penelitian berdaur ulang (siklus) yang terdiri dari: (1) perencanaan, (2) pelaksanaan, (3) pengamatan dan (4) refleksi (Arikunto, 2009: 16).

Proses penelitian tindakan kelas pada siklus I dilaksanakan seiring dengan perubahan yang ingin dicapai, yaitu meningkatakan hasil belajar matematika sesuai dengan perencanaan. Pada siklus II dilaksanakan sebagai tindak lanjut dari refleksi hasil tindakan dari siklus II menuju perubahan yang diinginkan. 
Tahapan atau siklus dari penelitian tindakan yang akan dilakukan sebagai berikut:

\section{Perencanaan (Planning)}

Langkah awal dalam penelitian ini adalah dengan menetapkan rencana yang akan dilakukan untuk meningkatkan proses dan hasil belajar siswa dalam mata pelajaran matematika melalui model pembelajaran Auditory, Intellectually, Repetition (AIR) pada siswa kelas V SD Inpres Perumnas Antang II/I Kota Makassar.

Perencanaan tersebut meliputi kegiatan-kegiatan berikut:

a. Calon peneliti melakukan analisis kurikulum untuk mengetahui kompetensi dasar yang akan disampaikan kepada siswa dengan menggunakan model pembelajaran Auditory, Intellectually, Repetition (AIR) .

b. Menyusun jadwal dan membuat rencana pelaksanaan pembelajaran (RPP) pada materi yang akan diajarkan dengan alokasi waktu 3 x 35 menit setiap pertemuan. Tindakan dalam penelitian ini direncanakan berlangsung dalam dua siklus adapun setiap siklus terdiri dari tiga pertemuan.

c. Membuat alat bantu belajar.

d. Menyusun evaluasi untuk menilai apakah tujuan-tujuan pembelajaran tercapai.

e. Membuat lembar observasi guru dan siswa untuk mengetahui bagaimana kondisi belajar mengajar di kelas pada waktu berlangsungnya kegiatan pembelajaran. 


\section{Pelaksanaan Tindakan (Acting)}

Tahap pelaksanaan tindakan adalah melaksanakan pembelajaran. Kegiatan pembelajaran untuk membantu siswa dalam memahami pembelajaran matematika. Pada tahap ini, peneliti juga bertindak sebagai guru yang melaksanakan tindakan sesuai dengan rencana yang telah dirancang berdasarkan model pembelajaran AIR. Tindakan ini dimaksudkan untuk memperbaiki keadaan atau kegiatan pembelajaran di kelas yang belum sesuai dengan yang diharapkan. Adapun kegiatan yang dilakukan pada tahap ini adalah menyajikan materi pelajaran dengan menerapkan model pembelajaran Auditory, Intellectually, Repetition (AIR).

Kegiatan ini dilaksanakan dalam dua siklus. Kegiatan akan berakhir setelah seluruh siswa mencapai indikator keberhasilan yang ditetapkan dalam pembelajaran matematika.

\section{Pengamatan (Observing)}

Kegiatan observasi ini adalah kegiatan mengamati aktivitas siswa antara lain berupa bertanya, mengerjakan LKS dan tugas-tugas lain yang diberikan oleh guru. Sedangkan aktivitas guru yang perlu diamati antara lain berupa respon guru terhadap pendapat siswa, membimbing siswa yang mengalami kesulitan dalam mengerjakan LKS dan mengecek hasil pekerjaan siswa. Kegiatan ini dilakukan selama pembelajaran berlangsung dengan menggunakan lembar observasi yang telah disiapkan oleh peneliti. Apabila ada hal-hal yang tidak terjaring pada lembar observasi yang menurut peneliti merupakan yang penting akan dilakukan pencatatan data. 


\section{Refleksi (Reflecting)}

Refleksi adalah serangkaian tindakan dalam penelitian yang mencakup kegiatan menganalisis, memahami, menyelesaikan dan menyimpulkan pengamatan. Hasil dari refleksi ini dilakukan untuk mengkaji dan merenungkan kembali informasi-informasi awal berkenaan dengan adanya ketidaksesuaian dengan praktek pembelajaran.

Untuk keberhasilan dapat dilihat dari dua aspek, yaitu aspek guru dan siswa. Keberhasilan dari aspek guru dapat dilihat pada kemampuan mengimplementasikan kegiatan pembelajaran melalui tiga tahap, yaitu tahap awal, inti dan akhir kegiatan pembelajaran dengan menerapkan model pembelajaran Auditory, Intellectually, Repetition (AIR) sedangkan pada siswa dapat dilihat pada saat pembelajaran dan hasil yang dicapai pada saat melakukan pengamatan pada pembelajran matematika. Menganalisis, memahami, menjelaskan dan menyimpulkan hasil dari pengamatan merupakan rangkaian kegiatan peneliti pada tahap refleksi. Peneliti menganalisis dan merenungkan hasil tindakan pada siklus tindakan sebagai bahan pertimbangan apakah pemberian tindakan yang dilakukan perlu diulangi atau tidak. Jika perlu diulangi, maka peneliti menyusun kembali rencana (revisi) untuk siklus berikutnya. 
Skema alur tindakan yang dilaksanakan dalam penelitian ini dapat dilihat pada gambar dibawah ini.

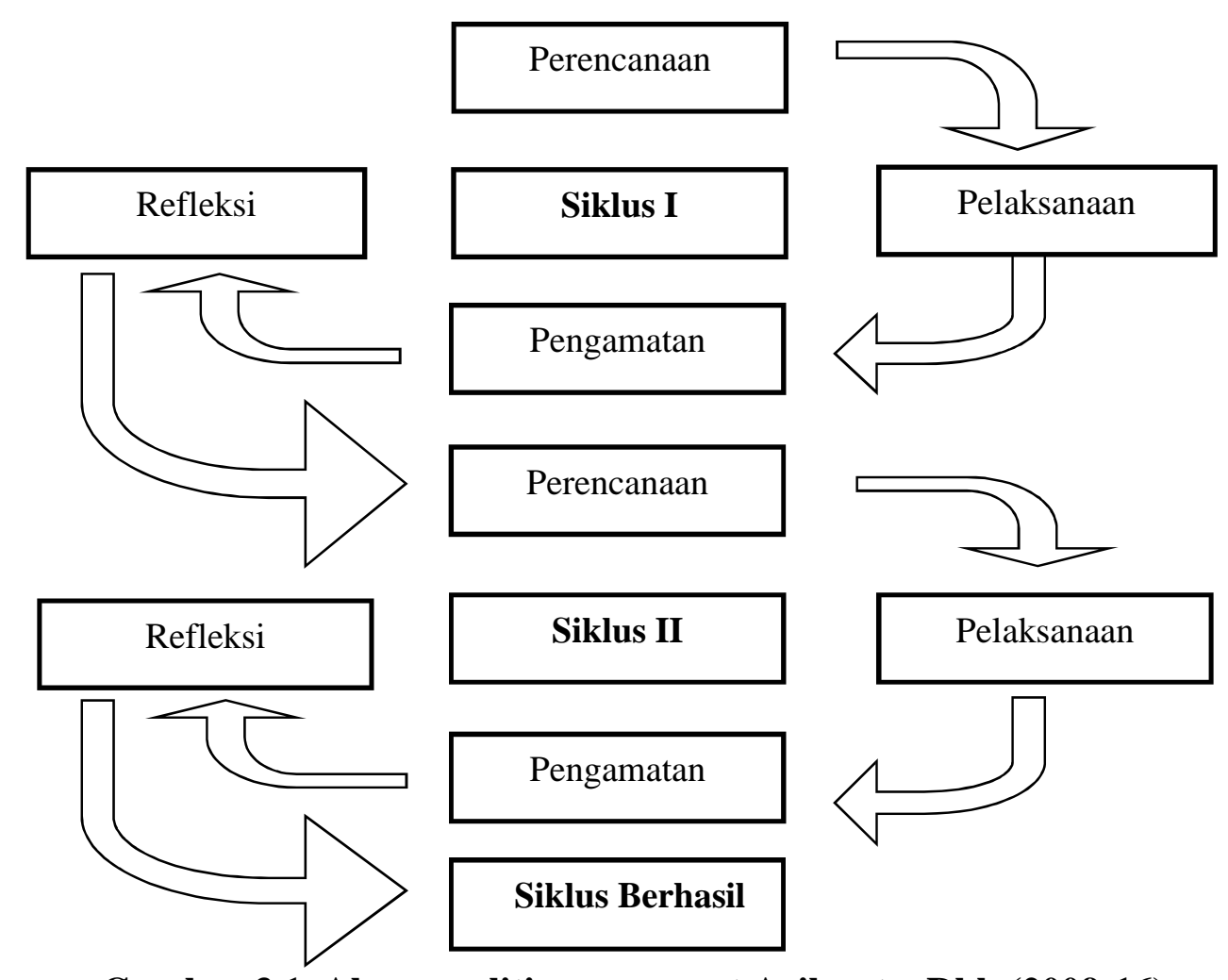

Gambar 3.1. Alur penelitian, menurut Arikunto, Dkk (2009:16)

\section{E. Teknik Pengumpulan Data dan Instrumen Penelitian}

\section{Teknik Pengumpulan Data}

Untuk mengumpulkan data dalam penelitian ini dilakukan dengan tes, wawancara, observasi atau pengamatan dan catatan lapangan. Keempat teknik tersebut diuraikan sebagai berikut:

a. Tes

Untuk mengetahui pemahaman siswa dilakukan tes, jenis tes yang digunakan yaitu tes tertulis. Pembuatan tes dilakukan melalui empat tahapan yaitu: (1) menyusun kisi-kisi soal yang berpedoman pada Kurikulum Tingkat Satuan Pendidikan (KTSP) 2006, (2) membuat butir-butir soal berdasarkan 
kisi-kisi yang dibuat bersama antara peneliti dan guru, (3) mengembangkan dan perbaikan konstruksi soal.

b. Wawancara

Wawancara dilaksanakan dengan subjek penelitian pada setiap akhir pembelajaran dan direkam, yang akan digunakan sebagai bahan refleksi untuk tindakan selanjutnya. Wawancara dimaksud untuk (1) mengetahui secara lebih mendalam terhadap latar kesulitan yang dihadapi siswa dalam menyelesaikan soal-soal tersebut, (2) mengetahui sejauh mana siswa telah benar-benar menunjukan kinerja yang diharapkan.

c. Observasi

Observasi dilakukan untuk mengamati aktivitas guru dan siswa selama kegiatan pembelajaran berlangsung, Sebagai upaya untuk mengetahui adanya kesesuaian antara perencanaan dan pelaksanaan tindakan. Observasi ini dilakukan oleh peneliti berpedoman pada lembar observasi.

Observasi dalam penelitian dikembangkan menjadi dua jenis, yaitu:

1) Observasi terhadap guru yang difokuskan pada langkah-langkah pembelajaran dalam meningkatkan pemahaman siswa.

2) Observasi terhadap siswa yang difokuskan terhadap pemahaman siswa selama proses pembelajaran matematika yang terjadi di kelas dengan menggunakan model pembelajaran Auditory, Intellectualy, Repetition (AIR). 


\section{d. Catatan Lapangan}

Catatan lapangan membuat hal-hal penting yang terjadi selama pembelajaran berlangsung, yang digunakan untuk melengkapi data yang tidak terekam dalam lembar observasi.

\section{Instrumen Penelitian}

Instrumen penelitian merupakan alat yang digunakan peneliti selama proses penelitian dilaksanakan. Komponen ini memegang posisi strategis dalam menentukan validitas hasil penelitian. Hasil penelitian yang valid diperoleh melalui pengumpulan data yang valid. Data yang valid diperoleh dengan menggunakan instrumen yang valid pula. Adapun instrumen yang digunakan dalam penelitian ini adalah:

a. Tes. Kegiatan tes dilaksanakan melalui pemberian soal individu kepada siswa dalam bentuk tes uraian yang harus dikerjakan dalam jangka waktu tertentu.

b. Observasi. Kegiatan ini dilaksanakan melalui pengamatan langsung observer terhadap kegiatan guru dan siswa selama pembelajaran berlangsung dengan menggunakan lembar observasi yang telah disiapkan dengan cara memberikan tanda centang pada kolom yang telah disediakan.

\section{F. Teknik Analisis Data}

Data yang dikumpulkan disetiap siklus akan dianalisis menggunakan Mixed Methods atau metode kombinasi antara kualitatif dan kuantitatif. Menurut Creswell (Emzir, 2014:9), dengan menggunakan kualitatif dan kuantitatif secara 
kombinasi akan dapat memperoleh pemahaman paling baik sehingga diperoleh data yang lebih komperensif, valid, reliabel dan obyektif.

\section{Kualitatif}

Data kualitatif adalah data yang berupa kalimat atau data yang dikategorikan berdasarkan kualitas objek yang diteliti. Data kualitatif yang diperoleh digunakan untuk menganalisa data yang memperlihatkan aktivitas guru dan siswa pada proses pembelajaran berlangsung.

\section{Kuantitatif}

Data kuantitatif diperoleh dari hasil tes yang diberikan pada saat berakhirnya siklus kegiatan. Analisis kuantitatif menyajikan data berupa angka dan persentasi keberhasilan belajar. Hasil tes dianalisis menggunakan rumus sebagai berikut:

Tingkat rata-rata keberhasilan

$$
\text { Rata-rata kelas }=\text { jumlah nilai keseluruhan }
$$

Untuk menghitung persentase ketuntasan belajar digunakan rumus sebagai berikut:

Persentase ketuntasan belajar_ $\underset{\text { jumlah siswa keseluruhan }}{=}$.

Tabel 3.2 Kriteria Hasil Belajar

\begin{tabular}{cc}
\hline Skor & Kriteria \\
\hline $86-100$ & Sangat Baik \\
$71-85$ & Baik \\
$56-70$ & Cukup \\
$41-55$ & Kurang \\
$<40$ & Sangat Kurang \\
\hline
\end{tabular}

Sunber: Rapor Kelas V SD Inspres Perumnas Antang II/I 


\section{G. Indikator Keberhasilan}

Indikator keberhasilan dalam penelitian tindakan kelas ini adalah $75 \%$ dari seluruh siswa memperoleh nilai $\geq 70$ atau jumlah siswa yang belajar tuntas meningkat. Hal tersebut berdasarkan Kriteria Ketuntasan Minimal (KKM) yang ditetapkan di SD Inpres Perumnas Antang II/I untuk mata pelajaran matematika.

Tabel 3.3 Kriteria Tingkat Keberhasilan

\begin{tabular}{cc}
\hline Tingkat Keberhasilan & Kualifikasi \\
\hline $81 \%-100 \%$ & Sangat Baik (SB) \\
$61 \%-80 \%$ & Baik (B) \\
$41 \%-60 \%$ & Cukup (C) \\
$21 \%-40 \%$ & Kurang (K) \\
$<21 \%$ & Sangat Kurang (SK) \\
\hline Sunber: Arikunto (2007)
\end{tabular}




\section{BAB IV}

\section{HASIL PENELITIAN DAN PEMBAHASAN}

\section{A. Hasil Penelitian}

Penelitian tindakan kelas ini dilaksanakan di SD Inpres Perumnas Antang II/I yang terletak di jalan Lasuloro Blok 1 No.15/17 Kecamatan Manggala Kota Makassar. SD Inpres Perumnas Antang II/I mempunyai 5 ruang kelas untuk kegiatan belajar. Jumlah guru yang aktif 21 orang yang terdiri dari kepala sekolah, guru kelas, dan tata usaha. Kelas V/A SD Inpres Perumnas Antang II/I merupakan kelas yang dipilih dalam pelaksanaan Penelitian Tindakan Kelas (PTK) karena hasil belajar matematika kelas V/A rendah. Subjek penelitian ini, yaitu 30 siswa yang terdiri dari 11 laki-laki dan 19 perempuan. Penelitian dilaksanakan pada bulan Juli 2018 dan penelitian dilaksanakan dalam 2 siklus, setiap siklus terdiri dari tiga pertemuan.

Hasil penelitian berupa paparan data yang didapatkan dari setiap siklus dalam menerapkan model pembelajaran Auditory, Intellectually, Repetition (AIR) pada pembelajaran matematika di kelas V SD Inpres Perumnas Antang II/I Kota Makassar.

\section{Paparan Data Siklus I}

\section{a. Tahap Perencanaan Siklus I}

Perencanaan pembelajaran disusun dan dikembangkan oleh peneliti dan guru dalam upaya meningkatkan hasil belajar matematika siswa. Peneliti dan guru terlebih dahulu menyamakan persepsi tentang Standar Kompetensi (SK) dan Kompetensi Dasar (KD) yang akan diajarkan dan jadwal pelaksanaan 
tindakan. Adapun SK untuk tiap pertemuan, yaitu melakukan operasi hitung bilangan bulat dalam pemecahan masalah serta KD yang akan diberikan siswa yaitu KD 1.1 melakukan operasi hitung bilangan bulat termasuk penggunaan sifat-sifatnya, pembulatan dan penaksiran. SK dan KD tersebut tercakup dalam lingkup pembahasan bilangan untuk kelas V semester I KTSP 2006.

Perencanaan yang dilakukan pada siklus I, yaitu. 1) membuat RPP; 2) Membuat Lembar Kerja Siswa (LKS); 3) Membuat soal evaluasi (tes formatif); 4) Membuat lembar observasi guru dan siswa.

Tindakan siklus I akan dilaksanakan dalam tiga pertemuan, yaitu pertemuan ke-1, pertemuan ke-2 dan pertemuan ke-3. Siklus I pertemuan ke-1 dilaksanakan pada hari senin tanggal 23 Juli 2018, pada pukul 13.00-14.30 WITA. Pembelajaran ini berlangsung selama 90 menit dengan materi pembelajaran, yaitu penjumlahan dan pengurangan dengan menggunakan garis bilangan. Siklus I pertemuan ke-2 dilaksanakan pada hari selasa tanggal 24 Juli 2018 mulai pukul 13.00-14.30 WITA. Pembelajaran ini berlangsung selama 90 menit dengan materi penjumlahan dan pengurangan tanpa menggunakan garis bilangan. Siklus I pertemuan ke-3 dilaksanakan pada rabu tanggal 25 juli 2018 pada pukul 13.00-14.300 WITA dengan materi pengurangan bilangan bulat tanpa menggunakan garis bilangan.

Tujuan pembelajaran pada pertemuan pertama, yaitu 1) siswa dapat melakukan penjumlahan bilangan bulat dengan menggunakan garis bilangan, 
2) siswa dapat melakukan pengurangan bilangan bulat dengan menggunakan garis bilangan.

Tujuan pembelajaran pada pertemuan kedua, yaitu 1) siswa dapat menghitung hasil penjumlahan bilangan bulat tanpa menggunakan garis bilangan, 2) siswa dapat menghitung hasil pengurangan bilangan bulat tanpa menggunakan garis bilangan. Tujuan pembelajaran pada pertemuan ketiga, yaitu 1) siswa dapat menghitung hasil pengurangan bilangan bulat tanpa menggunakan garis bilangan.

Saat pelaksanaan tindakan peneliti bertindak sebagai guru dalam proses pembelajaran khususnya mata pelajaran matematika. Sedangkan kegiatan pengamatan (observasi) akan dilaksanakan oleh guru kelas V selaku observer bertugas mengamati dengan baik seluruh kegiatan yang berlangsung selama proses pembelajaran dengan mengisi lembar observasi yang telah disediakan. Kegiatan pembelajaran yang disusun dapat dilihat dalam RPP pada lampiran 1 untuk pertemuan ke-1, pada lampiran 6 untuk pertemuan ke-2 dan pada lampiran 11 untuk pertemuan ke-3.

b. Tahap Pelaksanaan Siklus I

1) Pelaksanaan Siklus I pertemuan ke-1

Siklus I pertemuan ke-1 dilaksanakan pada hari senin tanggal 23 Juli 2018, pukul 13.00-14.30 WITA dengan alokasi waktu 2 x 45 menit.

Pembelajaran ini berlangsung selama 90 menit yang diikuti oleh seluruh siswa kelas V SD Inpres Perumnas Antang II/I Kota Makassar yang berjumlah 30 orang dengan materi pembelajaran yaitu penjumlahan dan 
pengurangan bilangan bulat dengan menggunakan garis bilangan. Pembelajaran dibagi menjadi tiga kegiatan, yaitu kegiatan awal dengan waktu \pm 10 menit, kegiatan inti \pm 70 menit dan kegiatan inti \pm 10 menit. Proses pembelajaran dengan menerapkan model pembelajaran AIR dapat dideskripsikan sebagai berikut.

a) Kegiatan Awal

Pada kegiatan awal guru mengawali pembelajaran dengan mengucapkan salam, mengecek kebersihan kelas. Guru menunjuk siswa untuk memimpin doa. Setelah itu, mengisi daftar hadir dan memotivasi siswa sebelum belajar. Selanjutnya guru melakukan apersepsi yang berkaitan dengan materi yang telah dipelajari, kemudian mengaitkannya dengan materi yang akan dipelajari yaitu penjumlahan dan pengurangan bilangan bulat dengan menggunakan garis bilanganserta menyebutkan tujuan pembelajaran yang akan dicapai, yaitu melakukan penjumlahan bilangan bulat dengan menggunakan garis bilangan dan melakukan pengurangan bilangan bulat dengan menggunakan garis bilangan, seluruh siswa menyimak dengan baik.

b) Kegiatan Inti

Kegiatan inti diawali dengan diterapkannya tahapan model pembelajaran AIR yang dimulai dengan tahap auditory. Mula-mula guru menjelaskan materi dengan sangat baik, kemudian guru mengelompokkan siswa ke dalam 6 kelompok yang terdiri dari 5 anggota kelompok dengan mengatur siswa duduk dengan kelompoknya tanpa mempertimbangkan kemampuan siswa ini dinilai kurang. Respon siswa sangat baik karena merasa 
pembelajaran berbeda seperti biasanya yaitu duduk berkelompok bersama teman. Guru pun sulit mengontrol kelas yang tampak sedikit ribut menghadapi berbagai ekspresi kebahagiaan siswa. Namun guru mampu mengatasinya dengan memberikan pujian-pujian kepada setiap kelompok sampai keadaan kelas menjadi stabil. Pelajaran dilanjutkan guru memberi tugas yang berbeda kepada setiap kelompok dalam bentuk LKS. Siswa pun menerima tugas yang berbeda untuk setiap kelompok dengan baik dan tertib sesuai intruksi yang diperintahkan guru. Guru memberikan kesempatan kepada siswa untuk bertanya apabila soal LKS kurang dipahami.

Tahap kedua, yaitu tahap intellectually. Dalam tahap ini, setiap kelompok terlihat kurang mampu dan bingung tentang apa yang harus dilakukan, maka guru pun membimbing sampai setiap anggota kelompok untuk berdiskusi dengan teman dalam satu kelompok sehingga dapat menyelesaikan LKS. Selanjutnya guru memberi kesempatan kepada perwakilan setiap kelompok memaparkan hasil diskusinya serta memberikan kesempatan kepada kelompok lain untuk bertanya dan mengemukakan pendapatnya. Guru membimbing siswa melakukan presentasi yang baik dibacakan meskipun diselingi sedikit candaan diantara mereka, setelah setiap kelompok mempresentasikan hasil diskusinya guru melakukan penilaian dengan memberikan penguatan terhadap hasil diskusi setiap kelompok, dan respon siswa lain pun bersorak gembira sehingga terlihat seluruh siswa aktif dalam pembelajaran. 
Tahap terakhir, yaitu tahap repetition dimana sebelumnya guru meminta siswa kembali ketempat duduk semula dan memberikan kesempatan kepada siswa untuk berpikir sejenak dan menanyakan materi pembelajaran yang belum dipahami sehingga dinilai kurang. Respon siswa kurang baik karena tidak ada satupun yang bertanya. Guru berpendapat bahwa seluruh siswa paham mengenai pelajaran maka dilanjutkan memberikan latihan soal. Guru memberikan latihan soal dengan membagikan lembar soal dinilai kurang baik tanpa memperjelas maksud soal sehingga berjalan tidak tertib, sebagian siswa terlihat bekerja sama dengan temannya dalam mengerjakan soal yang diberikan.

c) Kegiatan akhir

Pada kegiatan akhir, guru membimbing siswa menyimpulkan materi pembelajaran. Hanya beberapa siswa yang mampu menyimpulkan pelajaran dengan baik. Sebelum menutup pelajaran tak lupa guru menyampaikan motivasi dan pesan-pesan moral dan semua menyimak dengan baik bahkan ada diantara siswa yang mengatakan bahwa pembelajaran sangat menyenangkan dan berbeda seperti biasanya. Mendengar kesan itu membuat guru dan observer tersenyum bahagia. Akhirnya guru mengakhiri pembelajaran mengucapkan salam dan siswa pun istirahat.

2) Pelaksanaan Siklus I Pertemuan Ke-2

Siklus I pertemuan ke-2 dilaksanakan pada hari selasa 24 juli 2018 pukul 13.00-14.30 WITA. Pembelajaran ini berlangsung selama 90 menit yang terdiri dari kegiatan awal \pm 10 menit, kegiatan inti \pm 70 menit dan 
kegiatan akhir \pm 10 menit dengan materi, yaitu penjumlahan dan pengurangan bilangan bulat tanpa menggunakan garis bilangan.

a) Kegiatan Awal

Pada kegiatan awal guru mempersiapkan alat dan bahan yang akan digunakan dalam proses pembelajaran. Guru memulai pembeljaran dengan terlebih dahulu mengucapkan salam, mengecek kebersihan kelas kemudian memandu siswa untuk berdoa serta mengisi daftar hadir siswa. Setelah itu, menginstruksi siswa untuk mempersiapkan alat tulis dan memotivasi siswa sebelum belajar. Selanjutnya guru melakukan apersepsi tentang materi yang telah dipelajari pada pertemuan sebelumnya dan mengaitkan materi yang akan dipelajari. Dari penjelasan siswa, guru beralih pada kegiatan selajutnya yaitu menyampaikan tujuan pembelajaran yang akan dicapai antara lain menghitung hasil penjumlahan bilangan bulat tanpa menggunakan garis bilangan dan menghitung hasil pengurangan bilangan bulat tanpa menggunakan garis bilangan.

b) Kegiatan Inti

Kegiatan inti diawali dengan diterapkannya tahapan model pembelajaran AIR yang dimulai dengan tahap auditory. Pertama-tama guru menjelaskan materi dengan sangat baik dan meminta siswa untuk menyampaikan pemahamannya tentang penjumlahan dan pengurangan bilangan bulat tanpa menggunakan garis bilangan. Ternyata masih kurang siswa yang mengungkapkan pendapatnya, yaitu 5 orang. Maka dari itu, guru melengkapi pemahaman siswa tentang penjumlahan dan pengurangan 
bilangan bulat tanpa menggunakan garis bilangan dan meminta masingmasing siswa agar mencatat pada bukunya agar dapat dipelajari kembali. Kemudian guru memberikan contoh soal, setelah selesai, guru kemudian mengelompokkan siswa kedalam 6 kelompok yang terdiri dari 5 anggota kelompok dengan mengatur siswa duduk dengan kelompoknya tanpa mempertimbangkan kemampuan siswa ini dinilai kurang. Respon siswa kurang baik karena sebagian siswa kurang setuju dikelompokkan bersama temannya yang ditentukan guru sehingga kondisi kelas sedikit ribut dan tak terkendali. Guru pun mengontrol kelas yang tampak sedikit ribut dengan menaikkan volume suara sehingga seluruh siswa menjadi takut dan kembali duduk bersama dengan teman kelompoknya. Pelajaran dilanjutkan guru dengan memberi tugas yang berbeda kepada setiap kelompok dalam bentuk LKS dilakukan dengan baik. Siswa pun menerima tugas yang berbeda untuk setiap kelompok dengan baik dan tertib kemudian menyelesaikannya dengan tenang sesuai intruksi yang diperintahkan guru.

Tahap kedua, yaitu intellectually. Dalam tahap ini, guru membimbing siswa cara mengerjakan tugas setiap kelompok seperti pada pertemuan sebelumnya. Setiap kelompok langsung melakukan pembagian tugas dan menjalankan tugasnya masing-masing dengan tertib dan tenang walau sekalikali terdengar canda tawa diantara mereka namun tidak mengurangi fokus dalam belajar.

Tahap terakhir, yaitu tahap repetition atau pengulangan materi dimana sebelumnya guru meminta siswa kembali ketempat duduk semula dan 
memberikan kesempatan kepada siswa untuk berpikir sejenak dan menanyakan materi pembelajaran yang belum dipahami sehingga dinilai kurang. Namun respon siswa cukup baik itu terbukti 5 orang siswa bertanya tentang menghitung penjumlahan dan pengurangan operasi bilangan bulat dengan cepat. Guru kemudian menjelaskan pertanyaan siswa dan memberi penghargaan berupa penguatan pada siswa yang telah memberanikan diri bertanya. Guru kemudian memberikan latihan soal dengan cukup baik yaitu memberikan lembar soal dan memperjelas soal. Meski hal itu dilakukan cukup baik namun tetap berjalan tidak tertib, karena sebagian siswa terlihat bekerja sama dengan temannya dalam mengerjakan soal yang diberikan. Untuk mengatasi hal tersebut maka guru melakukan pengawasan dengan berjalan diantara para siswa sambil menegur siswa yang terlihat bekerja sama dengan teman sebangkunya.

c) Kegiatan Akhir

Pada kegiatan akhir, guru menyimpulkan materi pembelajaran dengan menunjuk 2 orang siswa menyimpulkan pelajaran dan melengkapi pemahaman siswa. Sebelum menutup pelajaran guru menyampaikan motivasi dan pesan-pesan moral agar siswa mengulang pelajaran di rumah dan semua siswa menyimak dengan baik. Pembelajaran berjalan dengan menyenangkan karena seluruh siswa aktif dalam proses pembelajaran serta kemampuan menginvestigasi mulai terbangun dalam diri siswa. Akhirnya guru mengakhiri pembelajaran mengucapkan salam. 
3) Pelaksanaan Siklus I pertemuan ke-3

Siklus I pertemuan ke-3 dilaksanakan pada hari rabu 25 juli 2018 pukul 13.00-14.30 WITA. Pembelajaran ini berlangsung selama 90 menit yang terdiri dari kegiatan awal \pm 10 menit, kegiatan inti \pm 70 menit dan kegiatan akhir \pm 10 menit dengan materi, yaitu pengurangan bilangan bulat tanpa menggunakan garis bilangan.

a) Kegiatan Awal

Pada kegiatan awal guru mempersiapkan alat dan bahan yang akan digunakan dalam proses pembelajaran. Guru memulai pembelajaran dengan terlebih dahulu mengucapkan salam, mengecek kebersihan kelas kemudian memandu siswa untuk berdoa serta mengisi daftar hadir siswa. Setelah itu, menginstruksi siswa untuk mempersiapkan alat tulis dan memotivasi siswa sebelum belajar. Selanjutnya guru melakukan apersepsi tentang materi yang telah dipelajari pada pertemuan sebelumnya dan mengaitkan materi yang akan dipelajari. Dari penjelasan siswa, guru beralih pada kegiatan selajutnya yaitu menyampaikan tujuan pembelajaran yang akan dicapai, yaitu menghitung hasil pengurangan bilangan bulat tanpa menggunakan garis bilangan.

b) Kegiatan Inti

Kegiatan inti diawali dengan diterapkannya tahapan model pembelajaran AIR yang dimulai dengan tahap auditory. Pertama-tama guru menjelaskan materi dengan sangat baik dan meminta siswa untuk menyampaikan pemahamannya tentang pengurangan bilangan bulat tanpa 
menggunakan garis bilangan. Kemudian, guru melengkapi pemahaman siswa pengurangan bilangan bulat tanpa menggunakan garis bilangan dan meminta masing-masing siswa agar mencatat pada bukunya agar dapat dipelajari kembali. Selanjutnya guru memberikan contoh soal. Setelah selesai, guru kemudian mengelompokkan siswa kedalam 6 kelompok yang terdiri dari 5 anggota kelompok dengan mengatur siswa duduk dengan kelompoknya tanpa mempertimbangkan kemampuan siswa ini dinilai kurang. Respon siswa kurang baik karena sebagian siswa kurang setuju dikelompokkan bersama temannya yang ditentukan guru sehingga kondisi kelas sedikit ribut dan tak terkendali. Guru pun mengontrol kelas yang tampak sedikit ribut dengan menaikkan volume suara sehingga seluruh siswa menjadi takut dan kembali duduk bersama dengan teman kelompoknya. Pelajaran dilanjutkan guru dengan memberi tugas yang berbeda kepada setiap kelompok dalam bentuk LKS dilakukan dengan baik. Siswa pun menerima tugas yang berbeda untuk setiap kelompok dengan baik dan tertib kemudian menyelesaikannya dengan tenang sesuai intruksi yang diperintahkan guru.

Tahap kedua, yaitu intellectually. Dalam tahap ini, guru membimbing siswa cara mengerjakan tugas setiap kelompok seperti pada pertemuan sebelumnya. Setiap kelompok langsung melakukan pembagian tugas dan menjalankan tugasnya masing-masing dengan tertib dan tenang walau sekalikali terdengar canda tawa diantara mereka namun tidak mengurangi fokus dalam belajar. 
Tahap terakhir, yaitu tahap repetition atau pengulangan materi dimana sebelumnya guru meminta siswa kembali ketempat duduk semula dan memberikan kesempatan kepada siswa untuk berpikir sejenak dan menanyakan materi pembelajaran yang belum dipahami sehingga dinilai kurang. Namun respon siswa cukup baik itu terbukti 5 orang siswa bertanya tentang menghitung pengurangan operasi bilangan bulat dengan cepat. Guru kemudian menjelaskan pertanyaan siswa dan memberi penghargaan berupa penguatan pada siswa yang telah memberanikan diri bertanya. Guru kemudian memberikan evaluasi mengenai materi yang telah diajarkan pada pertemuan sebelumnya. Evaluasi yang diberikan berjalan cukup tertib tetapi sebagian siswa terlihat bekerja sama dengan temannya dalam mengerjakan soal yang diberikan. Untuk mengatasi hal tersebut maka guru melakukan pengawasan dengan berjalan diantara para siswa sambil menegur siswa yang terlihat bekerja sama dengan teman sebangkunya.

c) Kegiatan Akhir

Pada kegiatan akhir, guru menyimpulkan materi pembelajaran dengan menunjuk 2 orang siswa menyimpulkan pelajaran dan melengkapi pemahaman siswa. Sebelum menutup pelajaran guru menyampaikan motivasi dan pesan-pesan moral agar siswa mengulang pelajaran di rumah dan semua siswa menyimak dengan baik. Pembelajaran berjalan dengan menyenangkan karena seluruh siswa aktif dalam proses pembelajaran serta kemampuan menginvestigasi mulai terbangun dalam diri siswa. Akhirnya guru mengakhiri pembelajaran mengucapkan salam. 
c. Hasil Observasi Siklus I

Observasi yang dilakukan pada pembelajaran matematika di kelas V SD Inpres Perumnas Antang II/I berkaitan dengan pelaksanaan pembelajaran sesuai dengan tahap-tahap model pembelajaran AIR yang telah disusun. Pada pembelajaran siklus I tentang pelaksanaan kegiatan pembelajaran yang berlangsung sesuai dengan yang telah disusun ternyata belum terlaksana secara maksimal. Hasil observasi pelaksanaan pembelajaran siklus I adalah sebagai berikut.

1) Kegiatan Mengajar Guru

Hasil observasi kegiatan mengajar guru adalah seperti yang ada dalam tabel berikut.

Tabel 4.1 Hasil Observasi Kegiatan Mengajar Guru

Siklus I

\section{Indikator (i) $\quad$ Pertemuan $1 \quad$ Pertemuan $2 \quad$ Pertemuan 3}

\begin{tabular}{llccccc} 
& $\mathbf{f}$ & $\mathbf{f . i}$ & $\mathbf{f}$ & $\mathbf{f . i}$ & $\mathbf{F}$ & $\mathbf{f . i}$ \\
\hline Sangat Baik (5) & 2 & 10 & 2 & 10 & 3 & 15 \\
Baik (4) & 2 & 8 & 2 & 8 & 3 & 12 \\
Cukup (3) & 3 & 9 & 5 & 15 & 5 & 15 \\
Kurang (2) & 8 & 16 & 6 & 12 & 4 & 8 \\
Sangat Kurang (1) & 0 & 0 & 0 & 0 & 0 & 0 \\
\hline Total Perolehan & & $\mathbf{4 3}$ & $\mathbf{4 5}$ & & $\mathbf{5 0}$ \\
Skor & $\mathbf{5 7 , 3 3 \%}$ & $\mathbf{6 0 \%}$ & $\mathbf{6 6 , 6 7 \%}$
\end{tabular}

Sumber: Hasil Observasi Siklus I Lampiran Halaman 80, 90 dan 97

Total Perolehan Skor $=\frac{43+45+50}{3}$

$$
=46
$$

Persentase Kegiatan Mengajar Guru $\frac{\text { total perolehan skor }}{\text { ckor NakciNas }}$ X 100\%

$$
=\frac{46}{75} \times 100 \%=61,33 \%
$$


Berdasarkan hasil observasi kegiatan mengajar guru diatas siklus I pada pertemuan pertama frekuensi (f) dikali indikator (i) total skor yang diperoleh 43, pada pertemuan kedua frekuensi (f) dikali indikator (i) total skor yang diperoleh 45, dan pada pertemua ketiga frekuensi (f) dikali indikator (i) total skor yang diperoleh 50, maka secara keseluruhan setelah total skor setiap pertemuan ditambah kemudian dibagi 3 diperoleh skor 46 dari 75 skor maksimal $(61,33 \%)$ termasuk dalam kualifikasi cukup (C) mengacu pada kriteria keberhasilan pembelajaran halaman 36. Hal ini menunjukkan bahwa guru telah melakukan proses pembelajaran menggunakan model pembelajaran AIR. Namun dalam pelaksanaannya belum optimal karena masih adanya kendala dalam pelaksanaan siklus 1 . Salah satu kendalanya yaitu guru belum optimal dalam membimbing siswa berkelompok.

2) Kegiatan Siswa

Hasil observasi kegiatan belajar siswa adalah seperti yang ada dalam tabel berikut.

Tabel 4.2 Hasil Observasi Kegiatan Belajar Siswa Siklus I

Indikator (i) $\quad$ Pertemuan $1 \quad$ Pertemuan $2 \quad$ Pertemuan 3

\begin{tabular}{llllllc} 
& F & $\mathbf{f . i}$ & $\mathbf{f}$ & $\mathbf{f . i}$ & $\mathbf{F}$ & $\mathbf{f . i}$ \\
\hline Sangat Baik (5) & 1 & 5 & 2 & 10 & 3 & 15 \\
Baik (4) & 1 & 4 & 2 & 8 & 2 & 8 \\
Cukup (3) & 6 & 18 & 4 & 12 & 6 & 18 \\
Kurang (2) & 7 & 14 & 7 & 14 & 4 & 8 \\
Sangat Kurang (1) & 0 & 0 & 0 & 0 & 0 & 0 \\
\hline Total Perolehan & & $\mathbf{4 1}$ & & $\mathbf{4 4}$ & & $\mathbf{4 9}$ \\
Skor & $\mathbf{5 4 , 6 7 \%}$ & $\mathbf{5 8 , 6 7 \%}$ & $\mathbf{6 5 , 3 3 \%}$
\end{tabular}

Sumber: Hasil Observasi Siklus I Lampiran Halaman 82, 92 dan 99 
Total Perolehan Skor $=\frac{41+44+49}{3}$

$$
=45
$$

Persentase Kegiatan Belajar Siswa $=\frac{\text { total perolehan skor X }}{\text { ckor NakciNaS }} 100 \%$

$$
=\frac{45}{75} \times 100 \%=60 \%
$$

Berdasarkan hasil observasi kegiatan belajar siswa diatas siklus I pada pertemuan pertama frekuensi (f) dikali indikator (i) total skor yang diperoleh 41, pada pertemuan kedua frekuensi (f) dikali indikator (i) total skor yang diperoleh 44, dan pada pertemua ketiga frekuensi (f) dikali indikator (i) total skor yang diperoleh 49, maka secara keseluruhan setelah total skor setiap pertemuan ditambah kemudian dibagi 3 diperoleh skor 45 dari 75 skor maksimal (60\%) termasuk dalam kualifikasi cukup (C) mengacu pada kriteria keberhasilan pembelajaran halaman 36 .

3) Hasil Tes Belajar Siklus I

Data tentang hasil belajar siswa pada siklus I digunakan untuk mengetahui nilai hasil belajar siswa setelah kegiatan tindakan siklus I dengan melakukan evaluasi terhadap siswa. Berdasarkan hasil evaluasi diperoleh data sebagai berikut.

Tabel 4.3 Distribusi Frekuensi Dan Persentase Hasil Belajar Siswa Siklus I

\begin{tabular}{cccc}
\hline Interval Nilai & Frekuensi (f) & Persentase & Kategori \\
\hline $0-40$ & 0 & 0 & Sangat Kurang \\
$41-55$ & 8 & $26,67 \%$ & Kurang \\
$56-70$ & 13 & $43,33 \%$ & Cukup \\
$71-85$ & 9 & $30 \%$ & Baik \\
$86-100$ & 0 & 0 & Sangat Baik \\
\hline Jumlah & $\mathbf{3 0}$ & $\mathbf{1 0 0 \%}$ & \\
\hline
\end{tabular}

Sumber: Hasil Evaluasi Siswa Siklus I Lampiran Halaman 103 
Berdasarkan tabel diatas, hasil belajar siklus I menunjukkan bahwa nilai rata-rata hasil belajar siswa sebesar 64,67 dapat dikatakan berada pada kategori cukup (C) dengan nilai terendah, yaitu 40 dan nilai tertinggi, yaitu 75.

\section{d. Refleksi Siklus I}

Refleksi siklus I dilaksanakan untuk meninjau dan merenungkan proses perencanaan dan pelaksanaan yang dianggap kurang terlaksana secara maksimal serta harus lebih ditingkatkan lagi dalam proses pembelajaran.

Pelaksanaan refleksi siklus I yaitu dengan melihat kembali proses pembelajaran yang telah dilakukan baik kegiatan mengajar guru maupun kegiatan belajar siswa berdasarkan tahap-tahap model pembelajaran AIR.

Pada tahap auditory, guru kurang maksimal dalam mengatur siswa dalam kelompok dan siswa kurang dalam melakukan pengumpulan informasi dari yang sudah dijelaskan guru. Maka hal tersebut berpengaruh terhadap keaktifan siswa dalam memahami materi yang dipelajari.

Pada tahap intellectually, dimana guru masih kurang maksimal membimbing siswa dalam melakukan perencanaan tugas untuk setiap anggota kelompok. Guru hanya menekankan pada arahan cara memperoleh jawaban yang benar tanpa menjelaskan cara persentasi yang baik. Hal ini berdampak pada semangat siswa yang menurun dalam pembelajaran karena sebagian besar siswa merasa kebingungan dalam hal mengerjakan tugas yang diberikan. 
Selanjutnya tahap repetition, guru kurang memberi kesempatan siswa untuk mengajukan pertanyaan tentang materi pelajaran yang belum dipahami. Selain itu, guru memberikan pengulangan dalam hal pemberian kuis atau soal latihan dilakukan dengan hanya membagikan lembar soal. Sehingga mengakibatkan sebagian siswa mengalami kebingungan dalam menyelesaikan soal dan melakukan perbuatan yang menyimpang seperti kerja sama dengan temannya, bercerita bahkan ada yang meninggalkan tempat duduk sehingga suasana kelas terlihat tidak demokratif.

Berdasarkan analisis dan refleksi di atas dan mengacu pada indikator keberhasilan yang telah ditetapkan peneliti, maka dapat disimpulkan bahwa proses belajar matematika dengan menerapkan model pembelajaran AIR siswa kelas V pada tindakan siklus I belum berhasil, maka perlu dilaksanakan siklus II.

\section{Paparan Data Siklus II}

a. Tahap Perencanaan Siklus II

Perencanaan pembelajaran disusun dan dikembangkan oleh peneliti dan guru dalam upaya meningkatkan hasil belajar matematika siswa. Peneliti dan guru terlebih dahulu menyamakan persepsi tentang Standar Kompetensi (SK) dan Kompetensi Dasar (KD) yang akan diajarkan dan jadwal pelaksanaan tindakan. Adapun SK untuk tiap pertemuan yaitu melakukan operasi hitung bilangan bulat dalam pemecahan masalah serta $\mathrm{KD}$ yang akan diberikan siswa yaitu KD 1.1 melakukan operasi hitung bilangan bulat termasuk penggunaan sifat-sifatnya, pembulatan dan penaksiran. SK dan KD tersebut 
tercakup dalam lingkup pembahasan bilangan untuk kelas V semester I KTSP 2006.

Perencanaan yang dilakukan pada siklus II, yaitu. 1) membuat RPP; 2) Membuat Lembar Kerja Siswa (LKS); 3) Membuat soal evaluasi (tes formatif); 4) Membuat lembar observasi guru dan siswa.

Tindakan siklus II akan dilaksanakan dalam tiga pertemuan, yaitu pertemuan ke-1, pertemuan ke-2 dan pertemuan ke-3. Siklus II pertemuan ke1 dilaksanakan pada hari senin tanggal 30 Juli 2018 pada pukul 07.30-09.15 WITA. Pembelajaran ini berlangsung selama 105 menit dengan materi pembelajaran, yaitu pengurangan dan perkalian bilangan bulat. Siklus II pertemuan ke-2 dilaksanakan pada hari selasa tanggal 31 Juli 2018 mulai pukul 07.30-09.15 WITA. Pembelajaran ini berlangsung selama 105 menit dengan materi perkalian bilangan bulat dan sifat-sifat operasi hitung bilangan bulat. Siklus II pertemuan ke-3 dilaksanakan pada hari rabu tanggal 01 Agustus 2018 pada pukul 07.30-09.15 WITA. Pembelajaran ini berlangsung selama 105 menit dengan materi sifat-sifat operasi hitung bilangan bulat.

Tujuan pembelajaran pada pertemuan pertama, yaitu 1) siswa dapat menghitung hasil pengurangan bilangan bulat tanpa menggunakan garis bilangan, 2) siswa dapat menghitung hasil perkalian bilangan bulat. Tujuan pembelajaran pada pertemuan kedua, yaitu 1) siswa dapat menghitung hasil perkalian bilangan bulat, 2) siswa dapat mengidentifikasi sifat-sifat operasi hitung bilangan bulat. Tujuan pembelajaran pada pertemuan ketiga, yaitu 1) siswa dapat menghitung hasil bilangan bulat menggunakan sifat-sifatnya. 
Saat pelaksanaan tindakan peneliti bertindak sebagai guru dalam proses pembelajaran khususnya mata pelajaran matematika. Sedangkan kegiatan pengamatan (observasi) akan dilaksanakan oleh guru kelas V selaku observer bertugas mengamati dengan baik seluruh kegiatan yang berlangsung selama proses pembelajaran dengan mengisi lembar observasi yang telah disediakan. Kegiatan pembelajaran yang disusun dapat dilihat dalam RPP pada lampiran 16 untuk pertemuan ke-1, pada lampiran 21 untuk pertemuan ke-2 dan pada lampiran 26 untuk pertemuan ke-3.

b. Tahap Pelaksanaan Siklus II

1) Pelaksanaan Siklus II Pertemuan Ke-1

Siklus II pertemuan ke-1 dilaksanakan pada hari senin tanggal 30 Juli 2018, pukul 07.30-09.15 WITA dengan alokasi waktu 3 x 35 menit. Pembelajaran ini berlangsung selama 105 menit yang diikuti oleh seluruh siswa kelas V SD Inpres Perumnas Antang II/I Kota Makassar yang berjumlah 30 orang dengan materi pembelajaran, yaitu pengurangan dan perkalian bilangan bulat. Pembelajaran dibagi menjadi tiga kegiatan yaitu kegiatan awal dengan waktu \pm 10 menit, kegiatan inti \pm 85 menit dan kegiatan inti \pm 10 menit. Proses pembelajaran dengan menerapkan model pembelajaran AIR dapat dideskripsikan sebagai berikut.

a) Kegiatan Awal

Pada kegiatan awal guru mengawali pembelajaran dengan mengucapkan salam, mengecek kebersihan kelas. Guru menunjuk siswa untuk memimpin doa. Setelah itu, mengisi daftar hadir dan memotivasi siswa 
sebelum belajar. Selanjutnya guru melakukan apersepsi yang berkaitan dengan materi yang telah dipelajari, kemudian mengaitkannya dengan materi yang akan dipelajari, yaitu pengurangan dan perkalian bilangan bulat, menyebutkan tujuan pembelajaran yang akan dicapai, yaitu menghitung hasil pengurangan bilangan bulat tanpa menggunakan garis bilangan dan menghitung hasil perkalian bilangan bulat, seluruh siswa menyimak dengan baik.

b) Kegiatan Inti

Kegiatan inti diawali dengan diterapkannya tahapan model pembelajaran AIR yaitu tahap auditory. Mula-mula guru menjelaskan materi dengan sangat baik, kemudian guru mengelompokkan siswa ke dalam 6 kelompok yang terdiri dari 5 anggota kelompok dengan mengatur siswa duduk dengan kelompoknya tanpa mempertimbangkan kemampuan siswa ini dinilai kurang. Guru pun sulit mengontrol kelas yang tampak sedikit ribut menghadapi berbagai ekspresi kebahagiaan siswa. Namun guru mampu mengatasinya dengan memberikan pujian-pujian kepada setiap kelompok sampai keadaan kelas menjadi stabil. Pelajaran dilanjutkan guru memberi tugas yang berbeda kepada setiap kelompok dalam bentuk LKS. Siswa pun menerima tugas yang berbeda untuk setiap kelompok dengan baik dan tertib sesuai intruksi yang diperintahkan guru. Guru memberikan kesempatan kepada siswa untuk bertanya apabila soal LKS kurang dipahami.

Tahap kedua, yaitu tahap intellectually dalam tahap ini setiap kelompok terlihat mengalami perubahan yang cukup baik karena telah dibimbing pada 
pertemuan sebelumnya mereka melakukan pembagian tugas yang baik dan menjalankan tugasnya masing-masing dengan tertib dan tenang walau sekalikali terdengar canda tawa dan tingkah lucu siswa. Setelah selesai masingmasing kelompok mempresentasikan hasil diskusinya dan kelompok yang lain merespon cukup baik setiap kelompok yang melakukan presentasi.

Tahap terakhir, yaitu tahap repetition atau pengulangan dimana sebelumnya guru meminta siswa kembali ketempat duduk semula dan memberikan kesempatan kepada siswa untuk berpikir sejenak dan menanyakan materi pembelajaran yang belum dipahami. Respon siswa cukup baik karena berani untuk bertanya. Guru memberikan latihan soal dengan membagikan lembar soal, meski hal itu dilakukan cukup baik namun pemberian latihan soal berjalan cukup tertib, siswa terlihat mulai mandiri mengerjakan soal yang diberikan.

c) Kegiatan Akhir

Pada kegiatan akhir, guru menyimpulkan materi pembelajaran dengan menunjuk beberapa orang siswa menyimpulkan pelajaran kemudian melengkapi pemahaman siswa. Sebelum menutup pelajaran guru menyampaikan motivasi dan pesan-pesan moral agar siswa mengulang pelajaran di rumah dan semua siswa menyimak dengan baik. Akhirnya guru mengakhiri pembelajaran mengucapkan salam dan siswa pun keluar kelas untuk istirahat dengan gembira. 
2) Pelaksanaan Siklus II Pertemuan ke-2

Siklus II pertemuan ke-2 dilaksanakan pada hari selasa 31 Juli 2018 pukul 07.30-09.15 WITA. Pembelajaran ini berlangsung selama 105 menit yang terdiri dari kegiatan awal \pm 10 menit, kegiatan inti \pm 85 menit dan kegiatan akhir \pm 10 menit dengan materi yaitu tentang perkalian bilangan bulat dan sifat-sifat operasi hitung bilangan bulat. Proses pembelajaran matematika siklus II pertemuan ke-2 dengan menerapkan model pembelajaran AIR dapat dideskripsikan sebagai berikut.

a) Kegiatan Awal

Pada kegiatan awal guru mempersiapkan alat dan bahan yang akan digunakan dalam proses pembelajaran. Guru memulai pembelajaran dengan terlebih dahulu mengucapkan salam, mengecek kebersihan kelas kemudian memandu siswa untuk berdoa serta mengisi daftar hadir siswa. Setelah itu, menginstruksi siswa untuk mempersiapkan alat tulis dan memotivasi siswa sebelum belajar. selanjutnya guru melakukan apersepsi tentang materi yang telah dipelajari pada pertemuan sebelumnya dan mengaitkan materi yang akan dipelajari. Dari penjelasan siswa, guru beralih pada kegiatan selanjutnya yaitu menyampaikan tujuan pembelajaran yang akan dicapai antara lain menghitung hasil perkalian bilangan bulat dan mengidentifikasi sifat-sifat operasi hitung bilangan bulat.

b) Kegiatan Inti

Tahap diawali dengan diterapkannya tahapan model pembelajaran AIR. Pertama-tama guru menjelaskan materi dengan sangat baik dan meminta 
siswa untuk menyampaikan pemahamannya tentang perkalian bilangan bulat dan sifat-sifat operasi hitung bilangan bulat siswa memberikan pendapatnya dengan sangat baik terlihat dari semangat mengemukakan pendapatnya sehingga tampak keseluruhan siswa berpendapat. Maka guru hanya memperjelas dan menyimpulkan pemahaman siswa. Selanjutnya guru memberikan siswa contoh soal, senagian besar siswa menyelesaikan dengan baik dan berani maju ke depan untuk menjawa soal di papan tulis. Selanjutnya guru mengelompokkan siswa kedalam 6 kelompok yang terdiri dari 5 anggota kelompok secara heterogen dengan menyebutkan nama-nama yang menjadi anggota kelompok baik kelompok 1, kelompok 2 atau kelompok 3 dan mengatur siswa duduk dengan kelompoknya. Siswa pun membentuk kelompoknya masing-masing dengan gembira dan tertib. Pelajaran kemudian dilanjutkan guru dengan memberi tugas yang berbeda kepada setiap kelompok dalam bentuk LKS dilakukan dengan baik. Siswapun menerima tugas yang berbeda untuk setiap kelompok dengan baik dan tertib.

Tahap kedua, yaitu tahap intellectually dimana guru membimbing setiap kelompok yang kesuliatan dalam mengerjakan tugas yang diberikan. Dalam tahap ini, setiap kelompok terlihat mengalami perubahan yang baik karena mereka melakukan pembagian tugas yang baik dan menjalankan tugasnya masing-masing dengan tertib dan tenang.

Tahap terakhir, yaitu tahap repetition atau pengulangan guru meminta siswa kembali ketempat duduk semula dan bertanya jawab tentang materi pembelajaran yang belum dipahami sehingga dinilai cukup baik. Guru 
kemudian memberikan latihan soal dengan mengatak siswa harus berlomba dalam mengerjakannya. Siswa langsung termotivasi dan semangat menyelesaikan soal dengan baik dan tertib, siswa terlihat mulai mandiri mengerjakan soal yang diberikan tanpa bekerja sama dengan teman sebangkunya.

c) Kegiatan Akhir

Pada kegiatan akhir, guru membimbing siswa menyimpulkan materi pembelajaran yang telah dipelajari. Kemudian memberikan motivasi dan pesan-pesan moral seperti mengulang kembali pelajaran di rumah. Guru mengakhiri pembelajaran dengan mengucapkan salam penutup.

3) Pelaksanaan Siklus II Pertemuan Ke-3

Siklus II pertemuan ke-3 dilaksanakan pada hari rabu 1 Agustus 2018 pukul 07.30-09.15 WITA. Pembelajaran ini berlangsung selama 105 menit yang terdiri dari kegiatan awal \pm 10 menit, kegiatan inti \pm 85 menit dan kegiatan akhir \pm 10 menit dengan materi yaitu tentang sifat-sifat operasi hitung bilangan bulat. Proses pembelajaran matematika siklus II pertemuan ke-3 dengan menerapkan model pembelajaran AIR dapat dideskripsikan sebagai berikut.

a) Kegiatan Awal

Pada kegiatan awal guru mempersiapkan alat dan bahan yang akan digunakan dalam proses pembelajaran. Guru memulai pembelajaran dengan terlebih dahulu mengucapkan salam, mengecek kebersihan kelas kemudian memandu siswa untuk berdoa serta mengisi daftar hadir siswa. Setelah itu, 
menginstruksi siswa untuk mempersiapkan alat tulis dan memotivasi siswa sebelum belajar. selanjutnya guru melakukan apersepsi tentang materi yang telah dipelajari pada pertemuan sebelumnya dan mengaitkan materi yang akan dipelajari. Dari penjelasan siswa, guru beralih pada kegiatan selanjutnya yaitu menyampaikan tujuan pembelajaran yang akan dicapai antara lain mengidentifikasi sifat-sifat operasi hitung bilangan bulat.

b) Kegiatan Inti

Tahap diawali dengan diterapkannya tahapan model pembelajaran AIR. Pertama-tama guru menjelaskan materi dengan sangat baik dan meminta siswa untuk menyampaikan pemahamannya tentang sifat-sifat operasi hitung bilangan bulat siswa memberikan pendapatnya dengan sangat baik terlihat dari semangat mengemukakan pendapatnya sehingga tampak keseluruhan siswa berpendapat. Maka guru hanya memperjelas dan menyimpulkan pemahaman siswa. Selanjutnya guru memberikan siswa contoh soal, senagian besar siswa menyelesaikan dengan baik dan berani maju ke depan untuk menjawa soal di papan tulis. Selanjutnya guru mengelompokkan siswa kedalam 6 kelompok yang terdiri dari 5 anggota kelompok secara heterogen dengan menyebutkan nama-nama yang menjadi anggota kelompok baik kelompok 1, kelompok 2 atau kelompok 3 dan mengatur siswa duduk dengan kelompoknya. Siswa pun membentuk kelompoknya masing-masing dengan gembira dan tertib. Pelajaran kemudian dilanjutkan guru dengan memberi tugas yang berbeda kepada setiap kelompok dalam bentuk LKS dilakukan 
dengan baik. Siswa pun menerima tugas yang berbeda untuk setiap kelompok dengan baik dan tertib.

Tahap kedua, yaitu tahap intellectually dimana guru membimbing setiap kelompok yang kesuliatan dalam mengerjakan tugas yang diberikan. Dalam tahap ini, setiap kelompok terlihat mengalami perubahan yang baik karena mereka melakukan pembagian tugas yang baik dan menjalankan tugasnya masing-masing dengan tertib dan tenang.

Tahap terakhir, yaitu tahap repetition atau pengulangan guru meminta siswa kembali ketempat duduk semula dan bertanya jawab tentang materi pembelajaran yang belum dipahami sehingga dinilai cukup baik. Guru kemudian memberikan evaluasi mengenai materi yang telah dipelajari pada pertemuan sebelumnya. Siswa semangat menyelesaikan soal dengan baik dan tertib, siswa terlihat mulai mandiri mengerjakan soal yang diberikan tanpa bekerja sama dengan teman sebangkunya.

c) Kegiatan Akhir

Pada kegiatan akhir, guru membimbing siswa menyimpulkan materi pembelajaran yang telah dipelajari. Kemudian memberikan motivasi dan pesan-pesan moral seperti mengulang kembali pelajaran di rumah. Guru mengakhiri pembelajaran dengan mengucapkan salam penutup.

\section{c. Hasil Observasi Siklus II}

Observasi yang dilakukan pada pembelajaran matematika di kelas V SD Inpres Perumnas Antang II/I berkaitan dengan pelaksanaan pembelajaran sesuai dengan tahap-tahap model pembelajaran AIR yang telah disusun. Pada 
pembelajaran siklus II tentang pelaksanaan kegiatan pembelajaran yang berlangsung sesuai dengan yang telah disusun ternyata terlaksana dengan maksimal. Berdasarkan hasil observasi menunjukkan bahwa pelaksanaan kegiatan pembelajaran mengalami peningkatan dari hasil observasi pelaksanaan kegiatan pembelajaran pada siklus I.

Hasil observasi pelaksanaan pembelajaran siklus II adalah sebagai berikut.

1) Kegiatan Mengajar Guru

Hasil observasi kegiatan mengajar guru adalah seperti yang ada dalam tabel berikut.

Tabel 4.4 Hasil Observasi Kegiatan Mengajar Guru

\begin{tabular}{lcccccc}
\hline & \multicolumn{9}{c}{ Siklus II } & \\
Indikator (i) & \multicolumn{2}{c}{ Pertemuan 1 } & \multicolumn{2}{c}{ Pertemuan 2 } & \multicolumn{2}{c}{ Pertemuan 3 } \\
& f & $\mathbf{f . i}$ & F & f.i & f & f.i \\
\hline Sangat Baik (5) & 3 & 15 & 4 & 20 & 6 & 30 \\
Baik (4) & 4 & 16 & 6 & 24 & 7 & 28 \\
Cukup (3) & 5 & 15 & 5 & 15 & 2 & 6 \\
$\quad$ Kurang (2) & 3 & 6 & 0 & 0 & 0 & 0 \\
Sangat Kurang (1) & 0 & 0 & 0 & 0 & 0 & 0 \\
\hline Total Perolehan & & $\mathbf{5 2}$ & & $\mathbf{5 9}$ & & $\mathbf{6 4}$ \\
Skor & & $\mathbf{6 9 , 3 3 \%}$ & $\mathbf{7 8 , 6 7 \%}$ & $\mathbf{8 5 , 3 3 \%}$ \\
\hline Persentase & &
\end{tabular}

Sumber: Hasil Observasi Siklus II Lampiran Halaman 111, 121 dan 128

Total Perolehan Skor $=\frac{52+59+64}{3}$

$$
=58
$$

Persentase Kegiatan Mengajar Guru $=\frac{\text { total perolehan skor X }}{\text { ckor NakciNaS }} 100 \%$

$$
=\frac{58}{75} \times 100 \%=77,33 \%
$$


Berdasarkan hasil observasi kegiatan mengajar guru diatas siklus II pada pertemuan pertama frekuensi (f) dikali indikator (i) total skor yang diperoleh 52, pada pertemuan kedua frekuensi (f) dikali indikator (i) total skor yang diperoleh 59, dan pada pertemua ketiga frekuensi (f) dikali indikator (i) total skor yang diperoleh 64, maka secara keseluruhan setelah total skor setiap pertemuan ditambah kemudian dibagi 3 diperoleh skor 58 dari 75 skor maksimal (77,33\%) termasuk dalam kualifikasi baik (B) mengacu pada kriteria keberhasilan pembelajaran halaman 36. Hal ini memperlihatkan proses pelaksanaan mengajar guru mengggunakan model pembelajaran AIR telah meningkat dari hasil observasi siklus I.

2) Kegiatan Siswa

Hasil observasi kegiatan belajar siswa adalah seperti yang ada dalam tabel berikut.

Tabel 4.5 Hasil Observasi Kegiatan Belajar Siswa

\begin{tabular}{|c|c|c|c|c|c|c|}
\hline \multirow{3}{*}{ Indikator (i) } & \multicolumn{6}{|c|}{ Siklus II } \\
\hline & \multicolumn{2}{|c|}{ Pertemuan 1} & \multicolumn{2}{|c|}{ Pertemuan 2} & \multicolumn{2}{|c|}{ Pertemuan 3} \\
\hline & $\mathbf{f}$ & f.i & f & f.i & $\mathbf{f}$ & f.i \\
\hline Sangat Baik (5) & 3 & 15 & 3 & 15 & 4 & 20 \\
\hline Baik (4) & 3 & 12 & 7 & 28 & 8 & 32 \\
\hline Cukup (3) & 6 & 18 & 5 & 15 & 3 & 9 \\
\hline Kurang (2) & 3 & 6 & 0 & 0 & 0 & 0 \\
\hline Sangat Kurang (1) & 0 & 0 & 0 & 0 & 0 & 0 \\
\hline $\begin{array}{l}\text { Total Perolehan } \\
\text { Skor }\end{array}$ & & 51 & & 58 & & 61 \\
\hline Persentase & \multicolumn{2}{|c|}{$68 \%$} & \multicolumn{2}{|c|}{$77,33 \%$} & \multicolumn{2}{|c|}{$81,33 \%$} \\
\hline
\end{tabular}

Sumber: Hasil Observasi Siklus II Lampiran Halaman 113, 123 dan 130 
Total Perolehan Skor $=\frac{51+58+61}{3}$

$$
=57
$$

Persentase Kegiatan Belajar Siswa $=\frac{\text { total perolehan skor X }}{\text { ckor NakciNaS }} 100 \%$

$$
=\frac{57}{75} \times 100 \%=76 \%
$$

Berdasarkan hasil observasi kegiatan belajar siswa diatas siklus II pada pertemuan pertama frekuensi (f) dikali indikator (i) total skor yang diperoleh 51, pada pertemuan kedua frekuensi (f) dikali indikator (i) total skor yang diperoleh 58, dan pada pertemua ketiga frekuensi (f) dikali indikator (i) total skor yang diperoleh 61, maka secara keseluruhan setelah total skor setiap pertemuan ditambah kemudian dibagi 3 diperoleh skor 57 dari 75 skor maksimal (76\%) termasuk dalam kualifikasi baik (B) mengacu pada kriteria keberhasilan pembelajaran halaman 36.

3) Hasil Tes Belajar Siklus II

Data tentang hasil belajar siswa pada siklus II digunakan untuk mengetahui perbandingan nilai siswa antara siklus I dan nilai siklus II. Data hasil belajar diperoleh setelah kegiatan tindakan siklus II dengan melakukan evaluasi terhadap siswa.

Berdasarkan hasil evaluasi kegiatan belajar siswa siklus II diperoleh data sebagai berikut.

Tabel 4.6 Distribusi Frekuensi Dan Persentase Hasil Belajar Siswa Siklus II

\begin{tabular}{cccc}
\hline Interval Nilai & Frekuensi (f) & Persentase & Kategori \\
\hline $0-40$ & 0 & 0 & Sangat Kurang \\
$41-55$ & 0 & 0 & Kurang \\
$56-70$ & 2 & $6,67 \%$ & Cukup \\
$71-85$ & 25 & $83,33 \%$ & Baik \\
$86-100$ & 3 & $10 \%$ & Sangat Baik \\
\hline Jumlah & $\mathbf{3 0}$ & $\mathbf{1 0 0 \%}$ & \\
\hline
\end{tabular}

Sumber: Hasil Evaluasi Siswa Siklus II Lampiran Halaman 135 
Berdasarkan tabel diatas, perhitungan hasil belajar siklus II menunjukkan bahwa nilai rata-rata hasil belajar siswa setelah dilsaksanakan siklus II terjadi peningkatan yaitu 80,33 sudah mencapai nilai KKM dengan nilai terendah, yaitu 65 dan nilai tertinggi, yaitu 90 .

d. Refleksi Siklus II

Pelaksanaan refleksi siklus II mengacu pada kegiatan mengajar dan kegiatan belajar yang telah dilakukan dalam menerapkan model pembelajaran AIR pada pelajaran matematika. Adapun perbaikan yang dilakukan guru adalah sebagai berikut.

Pada tahap auditory, guru telah efektif melakukan pengaturan siswa dalam bekerja kelompok. Sehingga siswa dapat sharing dan bekerja sama dengan teman kelompoknya yang memicu keaktifan setiap anggota kelompok dalam pembelajaran.

Pada tahap intellectually, guru membimbing siswa secara mendetail dalam hal pembagian tugas setiap anggota kelompok, cara memperoleh jawaban dan cara mempresentasikan laporan dengan baik dan benar. Sehingga setiap siswa berperan aktif dan mempertanggung jawabkan tugastugas yang telah diberikan dan saling berinteraksi dalam kelompok.

Selanjutnya tahap repetition, dimana guru melakukan tanya jawab dengan siswa terhadap materi yang telah dipelajari. Hal ini memicu keberanian siswa menjalin komunikasi yang baik dengan guru. Selain itu, dalam hal pemberian soal evaluasi (tes formatif) dilakukan guru dengan memperjelas maksud soal demi menghindari perspektif lain. 
Berdasarkan analisis dan refleksi siklus II diatas dapat disimpulkan bahwa pembelajaran matematika telah dikategorikan berhasil. Dengan demikian tujuan pembelajaran yang ditetapkan telah tercapai dan model pembelajaran AIR terbukti telah meningkatkan hasil belajar siswa dan mengembangkan kreativitas siswa, baik secara perorangan maupun kelompok karena menuntut siswa memiliki kemampuan yang baik dalam berkomunikasi maupun keterampilan berkelompok dalam pembelajaran.

Hasil tes siklus II menunjukkan bahwa siswa memperoleh peningkatan terhadap hasil belajar matematika, maka pada siklus II ini peneliti akan menghentikan penelitian karena sudah terlaksana dengan maksimum. Hal ini berarti bahwa dengan menerapkan model pembelajaran AIR pada pelajaran matematika telah berhasil.

Keberhasilan proses pembelajaran pada siklus I dan Siklus II dapat di lihat pada tabel di bawah ini.

Tabel 4.7 Tabel Keberhasilan Siklus I dan Siklus II

\begin{tabular}{lcccc}
\hline \multicolumn{1}{c}{ Aspek } & \multicolumn{2}{c}{ Siklus I } & \multicolumn{2}{c}{ Siklus II } \\
& $\boldsymbol{\%}$ & Kualifikasi & \% & Kualifikasi \\
\hline Guru & 61,33 & Cukup & 77,33 & Baik \\
Siswa & 60 & Cukup & 76 & Baik \\
$\begin{array}{l}\text { Hasil Belajar Siswa } \\
\text { (Ketuntasan) }\end{array}$ & 53,33 & Cukup & 93,33 & Sangat Baik \\
\hline
\end{tabular}

Sumber: Rekapitulasi Perolehan Nilai Siswa Lampiran Halaman 137

\section{B. Pembahasan}

Berdasarkan paparan data yang dikemukakan sebelumnya, maka pembahasan difokuskan pada aktifitas guru dan siswa dalam pembelajaran dengan menerapkan model pembelajaran AIR di kelas V SD Inpres Perumnas Antang II/I Kota Makassar. Pembahasan ini juga berkaitan dengan tahap-tahap model yang 
digunakan untuk meningkatkan hasil belajar siswa terhadap pembelajaran materi operasi hitung bilangan bulat yang terdiri atas: 1) tahap auditory, 2) tahap intellectually, 3) tahap repetition.

Dalam proses pembelajaran siswa merasa senang karena materi yang dipelajari dapat dipahami. Hal ini disebabkan tahap-tahap model yang dilakukan guru saat menyajikan materi sangat menyenangkan, pembelajaran dengan berkelompok membuat siswa terlibat aktif secara keseluruhan dan disela kegiatan pembelajaran guru kadang melontarkan kata-kata humor sehingga siswa tidak merasa bosan dalam belajar. Selain hal tersebut, model pembelajaran yang digunakan guru sangat menunjang keberhasilan dalam menyajikan materi. Model pembelajaran yang digunakan melalui tiga tahap, setiap tahap yang dilakukan mempunyai tujuan yang berbeda, sebagaimana yang telah diuraikan pada pelaksanaan tindakan siklus I dan siklus II.

Pada pembelajaran siklus I belum menunjukkan peningkatan yang maksimal karena belum mencapai indikator keberhasilan yang ditentukan maka dari itu dilanjutkan pada siklus II. Dalam pelaksanaan pembelajaran siklus II menunjukkan peningkatan pembelajaran yang dimaksimalkan guru sehingga pembelajaran berlangsung dengan baik. Pada tindakan siklus II keberhasilan sudah mencapai target yang diinginkan persentase hasil belajar siswa dapat dibandingkan dari siklus I hanya mencapai 53,33\% dengan kualifikasi cukup (C) meningkat menjadi 93,33\% dengan kualifikasi sangat baik (SB) pada siklus II.

Berdasarkan penelitian yang telah dilaksanakan, perolehan hasil belajar matematika siswa dari kedua siklus penelitian yang meningkat hingga mencapai 
indikator keberhasilan yang telah ditetapkan menunjukkan bahwa hasil belajar matematika siswa khususnya pada pokok bahasan operasi hitung bilangan bulat mengalami peningkatan yang signifikan. Peningkatan hasil belajar siswa diperoleh karena diterapkannya model pembelajaran AIR, sejalan dengan penelitian yang telah dilakukan sebelumnya oleh Khoirun Nesa pada tahun 2016 menunjukkan bahwa hasil belajar siswa meningkat jika diberi pembelajaran dengan menggunakan model pembelajaran AIR. Hal ini sejalan dengan teori belajar yang mendukung model pembelajaran AIR, yaitu teori Thorndike salah satunya mengungkapkan the law of exercise (hukum latihan) yang pada dasarnya mengatakan bahwa stimulus dan respon akan memiliki hubungan satu sama lain secara kuat jika proses pengulangan sering terjadi. Semakin banyak kegiatan pengulangan dilakukan maka hubungan yang terjadi akan semakin bersifat otomatis (Dimyati dan Mudjiono, 2009:45). Maka dari itu hasil belajar siswa yang semula rendah, dapat meningkat setelah pembelajaran matematika dengan menggunakan model pembelajaran AIR. 


\section{BAB V}

\section{PENUTUP}

\section{A. Kesimpulan}

Berdasarkan rumusan masalah, hasil analisis data dan pembahasan, maka hasil penelitian ini dapat disimpulkan bahwa dengan menggunakan model pembelajaran Auditory, Intellectually, Repetition (AIR) dapat meningkatkan hasil belajar matematika kelas V SD Inpres Perumnas Antang II/I Kota Makassar. Hal ini terbukti dengan adanya peningkatan hasil belajar matematika siswa yang ditandai dengan peningkatan persentase ketuntasan belajar pada setiap siklus. Persentase ketuntasan belajar siswa pada siklus I mencapai kualifikasi cukup dan meningkat pada siklus II hingga mencapai kualifikasi sangat baik.

\section{B. Saran}

Berdasarkan kesimpulan yang telah diuraikan, dikemukakan beberapa saran sebagai berikut:

1. Bagi guru kelas V SD Inpres Perumnas Antang II/I Kota Makassar agar dapat menerapkan model pembelajaran Auditory, Intellectually, Repetition (AIR) sebagai alternatif untuk meningkatkan hasil belajar matematika siswa.

2. Bagi peneliti lain agar dapat menerapkan model pembelajaran Auditory, Intellectually, Repetition (AIR) untuk meningkatkan hasil belajar siswa jika kelak menjadi guru. 


\section{DAFTAR PUSTAKA}

Amri. 2013. Pengembangan \& Model Pembelajaran dalam Kurikulum 2013.

Jakarta: PT. Prestasi Pustakarya

Anita, dkk. 2009. Strategi pembelajaran. Jakarta: Universitas Terbuka

Arikunto, Dkk. 2007. Evaluasi Program Pendidikan. Jakarta: Bumi Aksara . 2009. Penelitian Tindakan Kelas. Jakarta: PT Bumi Aksara 2011. Prosedur Penelitian Suatu Pendekatan Praktik. Jakarta: PT Rineka Cipta

BSNP. 2006. Permendiknas RI No.22 Tahun 2006 tentang Standar Isi Untuk Satuan Pendidikan Dasar dan Menengah. Jakarta

Depdiknas. 2007. Kamus Besar Bahasa Indonesia. Jakarta: Gramedia Pustaka Utama

Dimyati, dkk. 2009. Belajar dan Pembelajaran. Jakarta: Rineka Cipta

Emzir. 2014. Metode Penelitian Pendidikan. Jakarta: Rajawali Pers

Hamalik. 2005. Perencanaan Pengajaran Berdasarkan Pendekatan Sistem. Jakarta: PT Bumi Aksara

Huda. 2013. Model-model pengajaran dan Pembelajaran. Yogyakarta: Pustaka Belajar

Humaira. 2012. Langkah-Langkah Model Pembelajaran AIR. Diakses dari laman web tanggal 15 April 2018 dari http://digilib.unila.ac.id/4478/15/BAB\%20 II.pdf.

Jusmawati, H. U., \& Darwis, M. (2015). Efektivitas Penerapan Model Berbasis Masalah Setting Kooperatif dengan Pendekatan Saintifik dalam Pembelajaran Matematika di Kelas X SMA Negeri 11 Makassar. Daya Matematis: Jurnal Inovasi Pendidikan Matematika, 3(1), 30-40.

Komalasari. 2010. Pembelajaran Kontekstual. Bandung: PT Refika Aditama

Nesa. 2016. Keefektifan Model Auditory, Intelectually, Repetition (AIR) terhadap Minat dan Hasil Belajar IPS Siswa Kelas V SD Negeri Pekauman 5 Kota Tegal. Diakses dari laman web pada tanggal 19 Mei 2018 dari http://lib.unnes.ac.id/28312/1401412607.pdf

Sudjana. 2008. Penilaian Hasil Belajar Mengajar. Bandung: PT.Remaja Rosdakarya 
Susanto. 2013. Teori Belajar dan Pembelajaran di Sekolah Dasar. Jakarta: PT. Kharisma Putra Utama. 
Suprijono. 2013. Cooperative Learning Teori \& Aplikasi Paikem. Yogyakarta: Pustaka Belajar

Suprihatiningrum. 2013. Strategi Pembelajaran Teori dan Aplikasinya. Yogyakarta: Ar-Ruzz Media

Trianto. 2009. Mendesain Model Pembelajaran Inovatif Progresif. Jakarta: Kencana

Undang-Undang nomor 20 tahun 2003 tentang Sistem Pendidikan Nasional 
LAMPIRAN 


\section{Lampiran 1}

\section{RENCANA PELAKSANAAN PEMBELAJARAN (RPP) \\ SIKLUS I PERTEMUAN KE-1}

$\begin{array}{ll}\text { Satuan Pendidikan } & \text { : SD Inpres Perumnas Antang II/I } \\ \text { Kelas/ Semester } & \text { : V/I } \\ \text { Hari/Tanggal } & \text { : Senin / 23 Juli } 2018 \\ \text { Mata Pelajaran } & \text { : Matematika } \\ \text { Alokasi Waktu } & : 2 \text { X } 45 \text { Menit }\end{array}$

A. Standar Kompetensi

1. Melakukan operasi hitung bilangan bulat dalam pemecahan masalah

B. Kompetensi Dasar

1.1 Melakukan operasi hitung bilangan bulat termasuk penggunaan sifat sifatnya, pembulatan dan penaksiran

C. Indikator

1. Melakukan penjumlahan bilangan bulat dengan menggunakan garis bilangan

2. Melakukan pengurangan bilangan bulat dengan menggunakan garis bilangan

D. Tujuan Pembelajaran

1. Siswa dapat, melakukan penjumlahan bilangan bulat dengan menggunakan garis bilangan

2. Siswa dapat, melakukan pengurangan bilangan bulat dengan menggunakan garis bilangan

Karakter siswa yang diharapkan : Disiplin (Discipline), Rasa hormat

E. Materi Pembelajaran dan perhatian (respect), Tekun (diligence) dan Tanggung jawab (responsibility)

Operasi hitung bilangan bulat

F. Model dan Metode Pembelajaran

1. Model : Auditory, Intellectually, Repetition (AIR)

2. Metode : Ceramah, tanya jawab, demonstrasi, diskusi penugasan

G. Sumber Belajar

1. Silabus dan KTSP 2006 Mata Pelajaran Matematika

2. Ali Masykur, dkk, 2016, Senang Belajar Matematika kelas V, Jakarta: Yudhistira 


\section{H. Kegiatan Pembelajaran}

\begin{tabular}{|c|c|}
\hline Kegiatan Pembelajaran & Waktu \\
\hline $\begin{array}{l}\text { A. Kegiatan Awal } \\
\text { 1. Salam pembuka } \\
\text { 2. Mengecek kebersihan kelas } \\
\text { 3. Berdoa } \\
\text { 4. Mengisi daftar hadir } \\
\text { 5. Apersepsi melalui sesi tanya jawab } \\
\text { 6. Menyampaikan tujuan pembelajaran }\end{array}$ & $\begin{array}{l}10 \text { menit } \\
\text { (Klasikal) } \\
\text { (Klasikal) } \\
\text { (Klasikal) } \\
\text { (Klasikal) } \\
\text { (Klasikal) } \\
\text { (Klasikal) }\end{array}$ \\
\hline $\begin{array}{l}\text { B. Kegiatan Inti } \\
\text { Tahap Auditory } \\
\text { 1. Guru membagi siswa menjadi beberapa kelompok } \\
\text { kecil } \\
\text { 2. Guru memberikan LKS kepada siswa untuk } \\
\text { dikerjakan secara kelompok } \\
\text { 3. Guru memberi kesempatan kepada siswa untuk } \\
\text { bertanya mengenai soal LKS yang kurang dipahami } \\
\text { Tahap Intellectually } \\
\text { 4. Guru membimbing kelompok belajar siswa untuk } \\
\text { berdiskusi dengan teman dalam satu kelompok } \\
\text { sehingga dapat menyelesaikan LKS } \\
\text { 5. Guru memberi kesempatan kepada beberapa } \\
\text { kelompok untuk mempresentasikan hasil kerjanya, } \\
\text { serta memberikan kesempatan kepada kelompok lain } \\
\text { untuk bertanya dan mengemukakan pendapatnya } \\
\text { Tahap Repetition } \\
\text { 6. Guru melakukan pengulangan dengan memberikan } \\
\text { latihan soal atau kuis individu kepada siswa baik } \\
\text { dengan lisan maupun tulisan }\end{array}$ & $\begin{array}{l}70 \text { menit } \\
\text { (Klasikal) } \\
\text { (Klasikal) } \\
\text { (Klasikal) }\end{array}$ \\
\hline $\begin{array}{l}\text { C. Kegiatan Akhir } \\
\text { 1. Siswa dibimbing untuk menyimpulkan materi } \\
\text { pembelajaran } \\
\text { 2. Guru memberikan motivasi dan pesan-pesan moral } \\
\text { 3. Membaca doa } \\
\text { 4. Salam penutup }\end{array}$ & $\begin{array}{l}10 \text { menit } \\
\text { (Klasikal) } \\
\text { (Klasikal) } \\
\text { (Klasikal) } \\
\text { (Klasikal) }\end{array}$ \\
\hline
\end{tabular}

\section{Penilaian}

1. Teknik Penilaian

2. Instrumen Penilaian
: Tes tertulis

: Isian 


\section{J. Daftar Pustaka}

Ali Masykur, dkk, 2016, Senang Belajar Matematika kelas V, Jakarta: Yudhistira

Makassar, 23 Juli 2018

Guru Kelas V

Peneliti

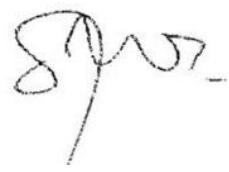

Nashrullah, S.Pd

Siti Nurfaidah

NIP. 198702142011011009

NIM: 093188793041

Mengetahui

Kepala SD Inpres Perumnas Antang II/I

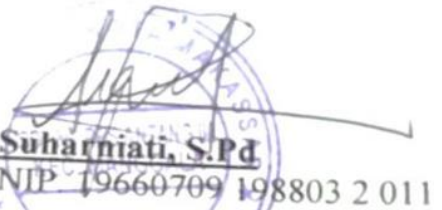


Lampiran 2

\section{LEMBAR KERJA SISWA (LKS) \\ SIKLUS I PERTEMUAN KE-1}

$\begin{array}{ll}\text { Mata Pelajaran } & \text { : Matematika } \\ \text { Kelas/ Semester } & : \text { V/I } \\ \text { Hari/Tanggal } & \text { : Senin / 23 Juli } 2018\end{array}$

Kelompok

Nama Anggota Kelompok

1.

2.

3.

4.

5 .

Kompetensi Dasar $\quad$ : 1.1 Melakukan operasi hitung bilangan bulat termasuk penggunaan sifat-sifatnya, pembulatan dan penaksiran

Tujuan Pembelajaran :1. Siswa dapat, melakukan penjumlahan bilangan bulat dengan menggunakan garis bilangan

2. Siswa dapat, melakukan pengurangan bilangan bulat dengan menggunakan garis bilangan

Langkah-langkah kegiatan :

a. Kerjakanlah soal-soal berikut ini bersama teman kelompokmu.

b. Jawablah soal-soal berikut menggunakan garis bilangan. 


\section{Soal!}

1. $14+(-7)=\quad 6 \cdot-12-(-15)=$

2. $5+(-16)=\quad 7.6-10=$

3. $18+(-9)=\quad 8 \cdot-12-(-10)=$

4. $-52+34=9 \cdot-14-17=$

5. $-10+(-17)=\quad 10 \cdot-15-21=$

\section{PEDOMAN PENSKORAN}

- Soal nomor 1-10 (masing-masing skor 10$)$, skor maksimal $=100$

- $\quad$ Skor 10, jika jawaban benar.

- $\quad$ Skor 5, jika jawaban kurang benar.

- $\quad$ Skor 0, jika jawaban salah/tidak menjawab sama sekali.

Nilai

$$
=\frac{\text { Skor Perolehan }}{\text { Skor Maksimal }} \times 100 \%
$$




\section{Lampiran 3}

PEROLEHAN SKOR LKS

SIKLUS I PERTEMUAN KE-1

\begin{tabular}{|c|c|l|c|c|c|}
\hline $\begin{array}{c}\text { No } \\
.\end{array}$ & Kelompok & \multicolumn{1}{|c|}{ Nama Siswa } & $\begin{array}{c}\text { Jumlah } \\
\text { Skor }\end{array}$ & Nilai & Keterangan \\
\hline 1 & 1 & $\begin{array}{l}\text { 1. Asnidar Tri Brata } \\
\text { 2. Fitri Dwi Handayani } \\
\text { 3. Katara }\end{array}$ & 60 & 60 & Tidak \\
Tuntas \\
\hline 2
\end{tabular}

Nilai KKM

$: \geq 70$

Rata-rata

$=\frac{\text { Jumlah Skor }}{\text { Jumlah Kelompok }}=\frac{370}{6}=61,67$ 


\section{Lampiran 4}

\section{HASIL OBSERVASI KEGIATAN MENGAJAR GURU}

\section{SIKLUS I PERTEMUAN KE-1}

$\begin{array}{ll}\text { Mata Pelajaran } & \text { : Matematika } \\ \text { Materi Pokok } & \text { : Operasi Hitung Bilangan Bulat } \\ \text { Nama Peneliti } & \text { : Siti Nurfaidah } \\ \text { Hari/Tanggal } & \text { : Senin/ 23 Juli } 2018\end{array}$

Petunjuk : Berilah tanda centang $(\sqrt{ })$ pada kolom tersedia sesuai dengan pengamatan anda pada saat guru/peneliti melaksanakan pembelajaran.

\begin{tabular}{|c|c|c|c|c|c|c|}
\hline \multirow{2}{*}{ No } & \multirow{2}{*}{ Aktivitas yang diamati } & \multicolumn{5}{|c|}{ Skor } \\
\hline & & 1 & 2 & 3 & 4 & 5 \\
\hline 1 & Membuka pembelajaran dan mengucap salam & & & & & $\sqrt{ }$ \\
\hline 2 & $\begin{array}{l}\text { Mengkondisikan ruang kelas dan mempersiapkan } \\
\text { siswa untuk mengikuti pembelajaran. }\end{array}$ & & & & $\sqrt{ }$ & \\
\hline 3 & Mengajak siswa berdoa. & & & & & $\sqrt{ }$ \\
\hline 4 & Menyampaikan tujuan pembelajaran. & & & & $\sqrt{ }$ & \\
\hline 5 & Memberikan motivasi dan merumuskan masalah. & & $\sqrt{ }$ & & & \\
\hline 6 & Menyiapkan bahan ajar. & & $\sqrt{ }$ & & & \\
\hline 7 & $\begin{array}{l}\text { Membimbing siswa untuk mengumpulkan sebuah } \\
\text { informasi }\end{array}$ & & $\sqrt{ }$ & & & \\
\hline 8 & Membagi kelompok diskusi. & & & $\sqrt{ }$ & & \\
\hline 9 & $\begin{array}{l}\text { Memimpin jalannya diskusi dan membimbing } \\
\text { kelompok diskusi }\end{array}$ & & $\sqrt{ }$ & & & \\
\hline 10 & $\begin{array}{l}\text { Menjelaskan tentang materi yang telah } \\
\text { didiskusikan dan melakukan timbal balik. }\end{array}$ & & $\sqrt{ }$ & & & \\
\hline 11 & Membimbing siswa untuk membuat kesimpulan. & & $\sqrt{ }$ & & & \\
\hline 12 & Memberikan test dan evaluasi & & $\sqrt{ }$ & & & \\
\hline 13 & Memberikan siswa kesempatan untuk bertanya. & & & $\sqrt{ }$ & & \\
\hline 14 & Membuat kesimpulan bersama siswa. & & & $\sqrt{1}$ & & \\
\hline 15 & Melaukan refleksi bersama dengan siswa. & & $\sqrt{ }$ & & & \\
\hline \multirow{2}{*}{\multicolumn{2}{|c|}{ Jumlah }} & 0 & 8 & 3 & 2 & 2 \\
\hline & & 0 & 16 & 9 & 8 & 10 \\
\hline & Total Perolehan Skor & \multicolumn{5}{|c|}{43} \\
\hline & Persentase Pelaksanaan Mengajar Guru & \multicolumn{5}{|c|}{$57,33 \%$} \\
\hline
\end{tabular}




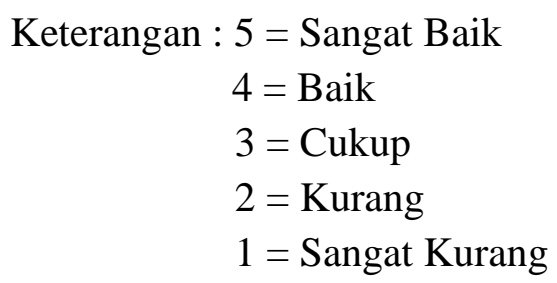
Persentase Pelaksanaan Kegiatan MengajarGuru $=\frac{\text { total perolehan skor X }}{\text { ckor NakciNas }} 100 \%$ $=\frac{43}{75} \times 100 \%=57,33 \%$

Makassar, 23 Juli 2018

Observer

Guru Kelas V

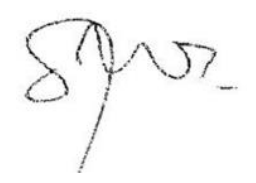

Nashrullah, S.Pd

NIP. 198702142011011009 


\section{Lampiran 5}

\section{HASIL OBSERVASI KEGIATAN BELAJAR SISWA \\ SIKLUS I PERTEMUAN KE-1}

$\begin{array}{ll}\text { Mata Pelajaran } & \text { : Matematika } \\ \text { Materi Pokok } & \text { : Operasi Hitung Bilangan Bulat } \\ \text { Nama Peneliti } & \text { : Siti Nurfaidah } \\ \text { Hari/Tanggal } & \text { : Senin/ 23 Juli } 2018\end{array}$

Petunjuk : Berilah tanda centang $(\sqrt{ })$ pada kolom tersedia sesuai dengan pengamatan anda pada saat guru/pebeliti melaksanakan pembelajaran.

\begin{tabular}{|c|l|l|l|l|l|l|}
\hline \multirow{2}{*}{ No } & \multicolumn{1}{|c|}{ Aktivitas yang diamati } & \multicolumn{3}{|c|}{ Skor } \\
\hline & & $\mathbf{1}$ & $\mathbf{2}$ & $\mathbf{3}$ & $\mathbf{4}$ & $\mathbf{5}$ \\
\hline 1 & Menjawab salam . & & & & $\sqrt{ }$ \\
\hline 2 & Bersiap untuk mengikuti pembelajaran. & & $\sqrt{ }$ & & \\
\hline 3 & Melaksanakan berdoa. & & & $\sqrt{ }$ & \\
\hline 4 & $\begin{array}{l}\text { Mendengarkan tujuan pembelajaran yang } \\
\text { disampaikan guru. }\end{array}$ & & $\sqrt{ }$ & & & \\
\hline 5 & Siswa memperhatikan penjelasan guru. & & $\sqrt{ }$ & & & \\
\hline 6 & Siswa menyiapkan peralatan belajar. & & & $\sqrt{ }$ & & \\
\hline 7 & $\begin{array}{l}\text { Melakukan pengumpulan informasi dari yang } \\
\text { sudah di jelaskan guru. }\end{array}$ & & $\sqrt{ }$ & & & \\
\hline 8 & $\begin{array}{l}\text { Siswa duduk sesuai kelompok yang sudah dibagi } \\
\text { guru. }\end{array}$ & & & $\sqrt{ }$ & & \\
\hline 9 & $\begin{array}{l}\text { Siswa melakukan kegiatan diskusi yang dibimbing } \\
\text { guru. }\end{array}$ & & & $\sqrt{ }$ & & \\
\hline 10 & Siswa bekerja sama dengan teman kelompok. & & $\sqrt{ }$ & & & \\
\hline 11 & Siswa mempresentasikan hasil diskusinya. & & & $\sqrt{ }$ & & \\
\hline 12 & Siswa melaksanakan test dan evalusi dari guru & & & $\sqrt{ }$ & & \\
\hline 13 & Siswa melakukan tanya jawab dengan guru & & $\sqrt{ }$ & & & \\
\hline 14 & Menyimpulkan hasil diskusi dan pembelajaran. & & $\sqrt{ }$ & & & \\
\hline 15 & Melakukan refleksi bersama guru & & $\sqrt{ }$ & & & \\
\hline & & 0 & 7 & 6 & 1 & 1 \\
\hline & Persentase Kegiatan Belajar Siswa & & $\mathbf{4 1}$ & 4 & 5 \\
\hline & & & $54,67 \%$ & \\
\hline
\end{tabular}


Keterangan : $5=$ Sangat Baik

$$
\begin{aligned}
& 4=\text { Baik } \\
& 3=\text { Cukup } \\
& 2=\text { Kurang } \\
& 1=\text { Sangat Kurang }
\end{aligned}
$$

$$
\begin{aligned}
\text { Persentase Kegiatan Belajar Siswa } & =\frac{\text { total perolehan skor } X 100 \%}{\text { ckor NakciNaS }} \\
& =\frac{41}{75} \times 100 \%=54,67 \%
\end{aligned}
$$

Makassar, 23 Juli 2018

Observer

Guru Kelas V

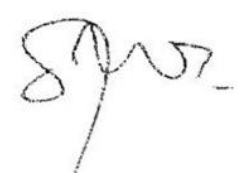

\section{Nashrullah, S.Pd}

NIP. 198702142011011009 
Lampiran 6

\section{RENCANA PELAKSANAAN PEMBELAJARAN (RPP) \\ SIKLUS I PERTEMUAN KE-2}

\author{
Satuan Pendidikan \\ Kelas/ Semester \\ Hari/Tanggal
}

Mata Pelajaran
: SD Inpres Perumnas Antang II/I

$: \mathrm{V} / \mathrm{I}$

: Selasa / 24 Juli 2018

: Matematika

Alokasi Waktu

: 2 X 45 Menit

\section{A. Standar Kompetensi}

1. Melakukan operasi hitung bilangan bulat dalam pemecahan masalah

\section{B. Kompetensi Dasar}

1.1 Melakukan operasi hitung bilangan bulat termasuk penggunaan sifat

C. Indikator sifatnya, pembulatan dan penaksiran

1. Menghitung hasil penjumlahan bilangan bulat tanpa menggunakan garis bilangan

2. Menghitung hasil pengurangan bilangan bulat tanpa menggunakan garis bilangan

\section{Tujuan Pembelajaran}

1. Siswa dapat, menghitung hasil penjumlahan bilangan bulat tanpa menggunakan garis bilangan

2. Siswa dapat, menghitung hasil pengurangan bilangan bulat tanpa menggunakan garis bilangan

Karakter siswa yang diharapkan : Disiplin (Discipline), Rasa hormat

dan perhatian (respect), Tekun (diligence) dan Tanggung jawab (responsibility)

E. Materi Pembelajaran

Operasi hitung bilangan bulat

F. Model dan Metode Pembelajaran

1. Model : Auditory, Intellectually, Repetition (AIR)

2. Metode : Ceramah, tanya jawab, demonstrasi,diskusi penugasan

G. Sumber Belajar

1. Silabus dan KTSP 2006 Mata Pelajaran Matematika

2. Ali Masykur, dkk, 2016, Senang Belajar Matematika kelas V, Jakarta: Yudhistira 


\section{H. Kegiatan Pembelajaran}

\begin{tabular}{|c|c|}
\hline Kegiatan Pembelajaran & Waktu \\
\hline $\begin{array}{l}\text { A. Kegiatan Awal } \\
\text { 1. Salam pembuka } \\
\text { 2. Mengecek kebersihan kelas } \\
\text { 3. Berdoa } \\
\text { 4. Mengisi daftar hadir } \\
\text { 5. Apersepsi melalui sesi tanya jawab } \\
\text { 6. Menyampaikan tujuan pembelajaran }\end{array}$ & $\begin{array}{l}10 \text { menit } \\
\text { (Klasikal) } \\
\text { (Klasikal) } \\
\text { (Klasikal) } \\
\text { (Klasikal) } \\
\text { (Klasikal) } \\
\text { (Klasikal) }\end{array}$ \\
\hline $\begin{array}{l}\text { B. Kegiatan Inti } \\
\text { Tahap Auditory } \\
\text { 1. Guru membagi siswa menjadi beberapa kelompok } \\
\text { kecil } \\
\text { 2. Guru memberikan LKS kepada siswa untuk } \\
\text { dikerjakan secara kelompok } \\
\text { 3. Guru memberi kesempatan kepada siswa untuk } \\
\text { bertanya mengenai soal LKS yang kurang dipahami } \\
\text { Tahap Intellectually } \\
\text { 4. Guru membimbing kelompok belajar siswa untuk } \\
\text { berdiskusi dengan teman dalam satu kelompok } \\
\text { sehingga dapat menyelesaikan LKS } \\
\text { 5. Guru memberi kesempatan kepada beberapa } \\
\text { kelompok untuk mempresentasikan hasil kerjanya, } \\
\text { serta memberikan kesempatan kepada kelompok lain } \\
\text { untuk bertanya dan mengemukakan pendapatnya } \\
\text { Tahap Repetition } \\
\text { 6. Guru melakukan pengulangan dengan memberikan } \\
\text { latihan soal atau kuis individu kepada siswa baik } \\
\text { dengan lisan maupun tulisan }\end{array}$ & $\begin{array}{l}70 \text { menit } \\
\text { (Klasikal) } \\
\text { (Klasikal) } \\
\text { (Klasikal) }\end{array}$ \\
\hline $\begin{array}{l}\text { C. Kegiatan Akhir } \\
\text { 1. Siswa dibimbing untuk menyimpulkan materi } \\
\text { pembelajaran } \\
\text { 2. Guru memberikan motivasi dan pesan-pesan moral } \\
\text { 3. Membaca doa } \\
\text { 4. Salam penutup }\end{array}$ & $\begin{array}{l}10 \text { menit } \\
\text { (Klasikal) } \\
\text { (Klasikal) } \\
\text { (Klasikal) } \\
\text { (Klasikal) }\end{array}$ \\
\hline
\end{tabular}

\section{Penilaian}

1. Teknik Penilaian

2. Instrumen Penilaian
: Tes tertulis

: Isian 


\section{J. Daftar Pustaka}

Ali Masykur, dkk, 2016, Senang Belajar Matematika kelas V, Jakarta: Yudhistira

Makassar, 24 Juli 2018

Guru Kelas V

Peneliti

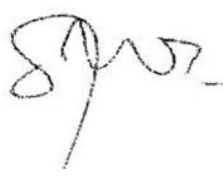

Nashrullah, S.Pd

Siti Nurfaidah

NIP. 198702142011011009

NIM: 093188793041

Mengetahui

Kepala SD Inpres Perumnas Antang II/I

$$
\text { Suharniati, S.Pd }
$$

NDP 196607091988032011 
Lampiran 7

\title{
LEMBAR KERJA SISWA (LKS)
}

SIKLUS I PERTEMUAN KE-2

\author{
Mata Pelajaran : Matematika \\ Kelas/ Semester $\quad$ : V/I \\ Hari/Tanggal $\quad$ : Selasa / 24 Juli 2018
}

Kelompok

Nama Anggota Kelompok

1.

2.

3.

4.

5 .

Kompetensi Dasar $\quad$ : 1.1 Melakukan operasi hitung bilangan bulat termasuk penggunaan sifat-sifatnya, pembulatan dan penaksiran

Tujuan Pembelajaran : 1. Siswa dapat, menghitung hasil penjumlahan bilangan bulat tanpa menggunakan garis bilangan

2. Siswa dapat, menghitung hasil pengurangan bilangan bulat tanpa menggunakan garis bilangan

Langkah-langkah kegiatan :

a. Kerjakanlah soal-soal berikut ini bersama teman kelompokmu.

b. Jawablah soal-soal berikut dengan benar. 


\section{Soal!}

1. $14+(-7)=\quad 6 .-12-(-15)=$

2. $5+(-16)=\quad 7.5-11=$

3. $18+(-9)=\quad 8 \cdot-12+(-5)=$

4. $-52+34=9 \cdot-9+8=$

5. $-10+(-17)=\quad 10.13+(-2)=$

\section{PEDOMAN PENSKORAN}

- Soal nomor 1-10 (masing-masing skor 10$)$, skor maksimal $=100$

- Skor 10, jika jawaban benar.

- Skor 5, jika jawaban kurang benar.

- Skor 0, jika jawaban salah/tidak menjawab sama sekali.

Nilai

$$
=\frac{\text { Skor Perolehan }}{\text { Skor Maksimal }} \times 100 \%
$$




\section{Lampiran 8}

PEROLEHAN SKOR LKS

SIKLUS I PERTEMUAN KE-2

\begin{tabular}{|c|c|c|c|c|c|}
\hline $\begin{array}{c}\text { No } \\
\text {. }\end{array}$ & Kelompok & Nama Siswa & $\begin{array}{c}\text { Jumlah } \\
\text { Skor }\end{array}$ & Nilai & Keterangan \\
\hline 1 & 1 & $\begin{array}{l}\text { 1. Nur Jannah } \\
\text { 2. Fitri Dwi Handayani } \\
\text { 3. Aurellia D.V } \\
\text { 4. Andi Ryan } \\
\text { 5. Rasya }\end{array}$ & 50 & 50 & $\begin{array}{l}\text { Tidak } \\
\text { Tuntas }\end{array}$ \\
\hline 2 & 2 & $\begin{array}{l}\text { 1. Asnidar Tri Brata } \\
\text { 2. Densel } \\
\text { 3. Nabila Alya } \\
\text { 4. A. Nur Azizah }\end{array}$ & 75 & 75 & Tuntas \\
\hline 3 & 3 & $\begin{array}{l}\text { 1. Muh. Henson } \\
\text { 2. Muh. Fahri } \\
\text { 3. Nur Syafika } \\
\text { 4. Dwi Yana Aulia } \\
\text { 5. Fitri Dwi Handayani }\end{array}$ & 50 & 50 & $\begin{array}{l}\text { Tidak } \\
\text { Tuntas }\end{array}$ \\
\hline 4 & 4 & $\begin{array}{l}\text { 1. A Nur Asmaul } \\
\text { 2. Nur Aisyah } \\
\text { 3. Alfira Maharani } \\
\text { 4. Humaira Natasha } \\
\text { 5. Annisa Zaharani }\end{array}$ & 70 & 70 & Tuntas \\
\hline 5 & 5 & $\begin{array}{l}\text { 1. A. Alfatia Alya } \\
\text { 2. Ainal Syahputra } \\
\text { 3. Katara } \\
\text { 4. Humaira Natasha } \\
\text { 5. Ghulam Sultan Dafi }\end{array}$ & 65 & 65 & $\begin{array}{l}\text { Tidak } \\
\text { Tuntas }\end{array}$ \\
\hline 6 & 6 & $\begin{array}{l}\text { 1. Abyan } \\
\text { 2. Arham Syahputra } \\
\text { 3. Nur Hikmah Nurdin } \\
\text { 4. Al Ifti Nur Wasisah } \\
\text { 5. Ayu Permata Sari }\end{array}$ & 80 & 80 & Tuntas \\
\hline \multicolumn{3}{|c|}{ Jumlah } & 390 & 390 & \multirow{2}{*}{$\begin{array}{c}\text { Tidak } \\
\text { Tuntas }\end{array}$} \\
\hline Rat: & & & 65 & 65 & \\
\hline
\end{tabular}

Nilai KKM

$: \geq 70$

Rata-rata

$=\frac{\text { Jumlah Skor }}{\text { Jumlah Kelompok }}=\frac{390}{6}=65$ 


\section{Lampiran 9}

\section{HASIL OBSERVASI KEGIATAN MENGAJAR GURU}

\section{SIKLUS I PERTEMUAN KE-2}

$\begin{array}{ll}\text { Mata Pelajaran } & \text { : Matematika } \\ \text { Materi Pokok } & \text { : Operasi Hitung Bilangan Bulat } \\ \text { Nama Peneliti } & \text { : Siti Nurfaidah } \\ \text { Hari/Tanggal } & \text { : Selasa/ 24 Juli 2018 }\end{array}$

Petunjuk : Berilah tanda centang $(\sqrt{ })$ pada kolom tersedia sesuai dengan pengamatan anda pada saat guru/peneliti melaksanakan pembelajaran.

\begin{tabular}{|c|c|c|c|c|c|c|}
\hline \multirow{2}{*}{ No } & \multirow{2}{*}{ Aktivitas yang diamati } & \multicolumn{5}{|c|}{ Skor } \\
\hline & & 1 & 2 & 3 & 4 & 5 \\
\hline 1 & Membuka pembelajaran dan mengucap salam & & & & & $\sqrt{ }$ \\
\hline 2 & $\begin{array}{l}\text { Mengkondisikan ruang kelas dan mempersiapkan } \\
\text { siswa untuk mengikuti pembelajaran. }\end{array}$ & & & & $\sqrt{ }$ & \\
\hline 3 & Mengajak siswa berdoa. & & & & & $\sqrt{ }$ \\
\hline 4 & Menyampaikan tujuan pembelajaran. & & & & $\sqrt{ }$ & \\
\hline 5 & Memberikan motivasi dan merumuskan masalah. & & & $\sqrt{ }$ & & \\
\hline 6 & Menyiapkan bahan ajar. & & & $\sqrt{ }$ & & \\
\hline 7 & $\begin{array}{l}\text { Membimbing siswa untuk mengumpulkan sebuah } \\
\text { informasi, }\end{array}$ & & $\sqrt{ }$ & & & \\
\hline 8 & Membagi kelompok diskusi. & & & $\sqrt{ }$ & & \\
\hline 9 & $\begin{array}{l}\text { Memimpin jalannya diskusi dan membimbing } \\
\text { kelompok diskusi }\end{array}$ & & & $\sqrt{ }$ & & \\
\hline 10 & $\begin{array}{l}\text { Menjelaskan tentang materi yang telah didiskusikan } \\
\text { dan melakukan timbal balik. }\end{array}$ & & $\sqrt{ }$ & & & \\
\hline 11 & Membimbing siswa untuk membuat kesimpulan. & & $\sqrt{ }$ & & & \\
\hline 12 & Memberikan test dan evaluasi & & $\sqrt{ }$ & & & \\
\hline 13 & Memberikan siswa kesempatan untuk bertanya. & & $\sqrt{ }$ & & & \\
\hline 14 & Membuat kesimpulan bersama siswa. & & & $\sqrt{ }$ & & \\
\hline 15 & Melaukan refleksi bersama dengan siswa. & & $\sqrt{ }$ & & & \\
\hline \multirow{2}{*}{\multicolumn{2}{|c|}{ Jumlah }} & 0 & 6 & 5 & 2 & 2 \\
\hline & & 0 & 12 & 15 & 8 & 10 \\
\hline & Total Perolehan Skor & \multicolumn{5}{|c|}{45} \\
\hline & Persentase Pelaksanaan Mengajar Guru & \multicolumn{5}{|c|}{$60 \%$} \\
\hline
\end{tabular}




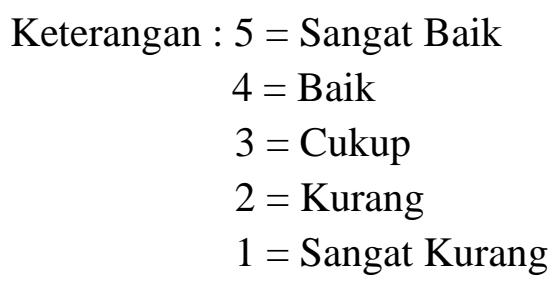

Persentase Pelaksanaan Kegiatan Mengajar Guru $=\frac{\text { total perolehan skor X X }}{\text { ckor NakciNaS }} 100 \%$ $=\frac{45}{75} \times 100 \%=60 \%$

Makassar, 24 Juli 2018

Observer

Guru Kelas V

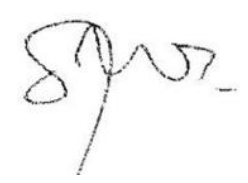

Nashrullah, S.Pd

NIP. 198702142011011009 


\section{Lampiran 10}

\section{HASIL OBSERVASI KEGIATAN BELAJAR SISWA SIKLUS I PERTEMUAN KE-2}

$\begin{array}{ll}\text { Mata Pelajaran } & \text { : Matematika } \\ \text { Materi Pokok } & \text { : Operasi Hitung Bilangan Bulat } \\ \text { Nama Peneliti } & \text { : Siti Nurfaidah } \\ \text { Hari/Tanggal } & \text { : Selasa/ 24 Juli } 2018\end{array}$

Petunjuk : Berilah tanda centang $(\sqrt{ })$ pada kolom tersedia sesuai dengan pengamatan anda pada saat guru/pebeliti melaksanakan pembelajaran.

\begin{tabular}{|c|c|c|c|c|c|c|}
\hline \multirow{2}{*}{ No } & \multirow{2}{*}{ Aktivitas yang diamati } & \multicolumn{5}{|c|}{ Skor } \\
\hline & & 1 & 2 & 3 & 4 & 5 \\
\hline 1 & Menjawab salam . & & & & & $\sqrt{ }$ \\
\hline 2 & Bersiap untuk mengikuti pembelajaran. & & & & $\sqrt{ }$ & \\
\hline 3 & Melaksanakan berdoa. & & & & & $\sqrt{ }$ \\
\hline 4 & $\begin{array}{l}\text { Mendengarkan tujuan pembelajaran yang } \\
\text { disampaikan guru. }\end{array}$ & & & & $\sqrt{ }$ & \\
\hline 5 & Siswa memperhatikan penjelasan guru. & & & $\sqrt{ }$ & & \\
\hline 6 & Siswa menyiapkan peralatan belajar. & & $\sqrt{ }$ & & & \\
\hline 7 & $\begin{array}{l}\text { Melakukan pengumpulan informasi dari yang sudah } \\
\text { di jelaskan guru. }\end{array}$ & & $\sqrt{ }$ & & & \\
\hline 8 & $\begin{array}{l}\text { Siswa duduk sesuai kelompok yang sudah dibagi } \\
\text { guru. }\end{array}$ & & & $\sqrt{ }$ & & \\
\hline 9 & $\begin{array}{l}\text { Siswa melakukan kegiatan diskusi yang dibimbing } \\
\text { guru. }\end{array}$ & & $\sqrt{ }$ & & & \\
\hline 10 & Siswa bekerja sama dengan teman kelompok. & & $\sqrt{ }$ & & & \\
\hline 11 & Siswa mempresentasikan hasil diskusinya. & & $\sqrt{ }$ & & & \\
\hline 12 & Siswa melaksanakan test dan evalusi dari guru & & $\sqrt{ }$ & & & \\
\hline 13 & Siswa melakukan tanya jawab dengan guru & & & $\sqrt{ }$ & & \\
\hline 14 & Menyimpulkan hasil diskusi dan pembelajaran. & & & $\sqrt{ }$ & & \\
\hline 15 & Melakukan refleksi bersama guru & & $\sqrt{ }$ & & & \\
\hline \multirow{2}{*}{\multicolumn{2}{|c|}{ Jumlah }} & 0 & 7 & 4 & 2 & 2 \\
\hline & & 0 & 14 & 12 & 8 & 10 \\
\hline & Total Perolehan Skor & \multicolumn{5}{|c|}{44} \\
\hline & Persentase Kegiatan Belajar Siswa & \multicolumn{5}{|c|}{$58,67 \%$} \\
\hline
\end{tabular}




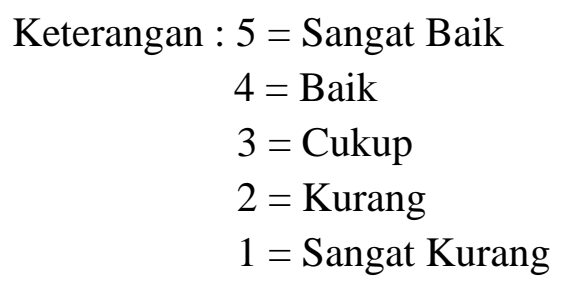

Persentase Kegiatan Belajar Siswa $=\frac{\text { total perolehan skor X }}{\text { ckor NakciNaS }} 100 \%$

$$
=\frac{44}{75} \times 100 \%=58,67 \%
$$

Makassar, 24 Juli 2018

Observer

Guru Kelas V

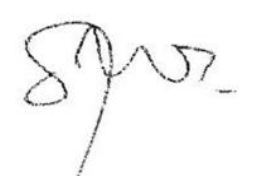

Nashrullah, S.Pd

NIP. 198702142011011009 
Lampiran 11

\section{RENCANA PELAKSANAAN PEMBELAJARAN (RPP) \\ SIKLUS I PERTEMUAN KE-3}

$\begin{array}{ll}\text { Satuan Pendidikan } & \text { : SD Inpres Perumnas Antang II/I } \\ \text { Kelas/ Semester } & \text { : V/I } \\ \text { Hari/Tanggal } & \text { : Rabu / 25 Juli } 2018 \\ \text { Mata Pelajaran } & \text { : Matematika } \\ \text { Alokasi Waktu } & : 2 \text { X } 45 \text { Menit }\end{array}$

A. Standar Kompetensi

1. Melakukan operasi hitung bilangan bulat dalam pemecahan masalah

B. Kompetensi Dasar

1.1 Melakukan operasi hitung bilangan bulat termasuk penggunaan sifat sifatnya, pembulatan dan penaksiran

C. Indikator

1. Menghitung hasil pengurangan bilangan bulat tanpa menggunakan garis bilangan

D. Tujuan Pembelajaran

1. Siswa dapat, menghitung hasil pengurangan bilangan bulat tanpa menggunakan garis bilangan

Karakter siswa yang diharapkan : Disiplin (Discipline), Rasa hormat

dan perhatian (respect), Tekun (diligence) dan Tanggung jawab

E. Materi Pembelajaran (responsibility)

Operasi hitung bilangan bulat

F. Model dan Metode Pembelajaran

1. Model : Auditory, Intellectually, Repetition (AIR)

2. Metode : Ceramah, tanya jawab, demonstrasi,diskusi penugasan

G. Sumber Belajar

1. Silabus dan KTSP 2006 Mata Pelajaran Matematika

2. Ali Masykur, dkk, 2016, Senang Belajar Matematika kelas V, Jakarta: Yudhistira 


\section{H. Kegiatan Pembelajaran}

\begin{tabular}{|c|c|}
\hline Kegiatan Pembelajaran & Waktu \\
\hline $\begin{array}{l}\text { A. Kegiatan Awal } \\
\text { 1. Salam pembuka } \\
\text { 2. Mengecek kebersihan kelas } \\
\text { 3. Berdoa } \\
\text { 4. Mengisi daftar hadir } \\
\text { 5. Apersepsi melalui sesi tanya jawab } \\
\text { 6. Menyampaikan tujuan pembelajaran }\end{array}$ & $\begin{array}{l}10 \text { menit } \\
\text { (Klasikal) } \\
\text { (Klasikal) } \\
\text { (Klasikal) } \\
\text { (Klasikal) } \\
\text { (Klasikal) } \\
\text { (Klasikal) }\end{array}$ \\
\hline $\begin{array}{l}\text { B. Kegiatan Inti } \\
\text { Tahap Auditory } \\
\text { 1. Guru membagi siswa menjadi beberapa kelompok } \\
\text { kecil } \\
\text { 2. Guru memberikan LKS kepada siswa untuk } \\
\text { dikerjakan secara kelompok } \\
\text { 3. Guru memberi kesempatan kepada siswa untuk } \\
\text { bertanya mengenai soal LKS yang kurang dipahami } \\
\text { Tahap Intellectually } \\
\text { 4. Guru membimbing kelompok belajar siswa untuk } \\
\text { berdiskusi dengan teman dalam satu kelompok } \\
\text { sehingga dapat menyelesaikan LKS } \\
\text { 5. Guru memberi kesempatan kepada beberapa } \\
\text { kelompok untuk mempresentasikan hasil kerjanya, } \\
\text { serta memberikan kesempatan kepada kelompok lain } \\
\text { untuk bertanya dan mengemukakan pendapatnya } \\
\text { Tahap Repetition } \\
\text { 6. Guru melakukan pengulangan dengan memberikan } \\
\text { latihan soal atau kuis individu kepada siswa baik } \\
\text { dengan lisan maupun tulisan }\end{array}$ & $\begin{array}{l}70 \text { menit } \\
\text { (Klasikal) } \\
\text { (Klasikal) } \\
\text { (Klasikal) }\end{array}$ \\
\hline $\begin{array}{l}\text { C. Kegiatan Akhir } \\
\text { 1. Siswa dibimbing untuk menyimpulkan materi } \\
\text { pembelajaran } \\
\text { 2. Guru memberikan motivasi dan pesan-pesan moral } \\
\text { 3. Membaca doa } \\
\text { 4. Salam penutup }\end{array}$ & $\begin{array}{l}10 \text { menit } \\
\text { (Klasikal) } \\
\text { (Klasikal) } \\
\text { (Klasikal) } \\
\text { (Klasikal) }\end{array}$ \\
\hline
\end{tabular}

\section{Penilaian}

3. Teknik Penilaian

4. Instrumen Penilaian
: Tes tertulis

: Isian 


\section{J. Daftar Pustaka}

Ali Masykur, dkk, 2016, Senang Belajar Matematika kelas V, Jakarta: Yudhistira

Makassar, 25 Juli 2018

Guru Kelas V

Peneliti

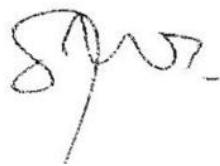

Nashrullah, S.Pd

Siti Nurfaidah

NIP. 198702142011011009

NIM: 093188793041

Mengetahui

Kepala SD Inpres Perumnas Antang II/I

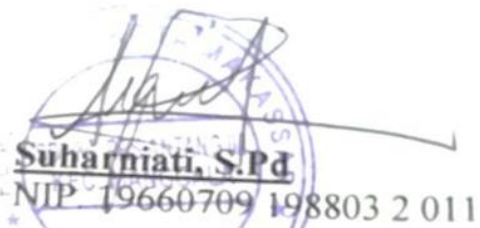




\section{Lampiran 12}

\section{HASIL OBSERVASI KEGIATAN MENGAJAR GURU SIKLUS I PERTEMUAN KE-3}

$\begin{array}{ll}\text { Mata Pelajaran } & \text { : Matematika } \\ \text { Materi Pokok } & \text { : Operasi Hitung Bilangan Bulat } \\ \text { Nama Peneliti } & \text { : Siti Nurfaidah } \\ \text { Hari/Tanggal } & \text { : Rabu/ 25 Juli } 2018\end{array}$

Petunjuk : Berilah tanda centang $(\sqrt{ })$ pada kolom tersedia sesuai dengan pengamatan anda pada saat guru/peneliti melaksanakan pembelajaran.

\begin{tabular}{|c|c|c|c|c|c|c|}
\hline \multirow{2}{*}{ No } & \multirow{2}{*}{ Aktivitas yang diamati } & \multicolumn{5}{|c|}{ Skor } \\
\hline & & 1 & 2 & 3 & 4 & 5 \\
\hline 1 & Membuka pembelajaran dan mengucap salam & & & & & $\sqrt{ }$ \\
\hline 2 & $\begin{array}{l}\text { Mengkondisikan ruang kelas dan mempersiapkan } \\
\text { siswa untuk mengikuti pembelajaran. }\end{array}$ & & & & & $\sqrt{ }$ \\
\hline 3 & Mengajak siswa berdoa. & & & & & $\sqrt{ }$ \\
\hline 4 & Menyampaikan tujuan pembelajaran. & & & & $\sqrt{ }$ & \\
\hline 5 & Memberikan motivasi dan merumuskan masalah. & & & $\sqrt{ }$ & & \\
\hline 6 & Menyiapkan bahan ajar. & & & & $\sqrt{ }$ & \\
\hline 7 & $\begin{array}{l}\text { Membimbing siswa untuk mengumpulkan sebuah } \\
\text { informasi, }\end{array}$ & & $\sqrt{ }$ & & & \\
\hline 8 & Membagi kelompok diskusi. & & & & $\sqrt{ }$ & \\
\hline 9 & $\begin{array}{l}\text { Memimpin jalannya diskusi dan membimbing } \\
\text { kelompok diskusi }\end{array}$ & & & $\sqrt{ }$ & & \\
\hline 10 & $\begin{array}{l}\text { Menjelaskan tentang materi yang telah didiskusikan } \\
\text { dan melakukan timbal balik. }\end{array}$ & & $\sqrt{ }$ & & & \\
\hline 11 & Membimbing siswa untuk membuat kesimpulan. & & & $\sqrt{ }$ & & \\
\hline 12 & Memberikan test dan evaluasi & & & $\sqrt{ }$ & & \\
\hline 13 & Memberikan siswa kesempatan untuk bertanya. & & $\sqrt{ }$ & & & \\
\hline 14 & Membuat kesimpulan bersama siswa. & & & $\sqrt{ }$ & & \\
\hline 15 & Melaukan refleksi bersama dengan siswa. & & $\sqrt{ }$ & & & \\
\hline \multirow{2}{*}{\multicolumn{2}{|c|}{ Jumlah }} & 0 & 4 & 5 & 3 & 3 \\
\hline & & 0 & 8 & 15 & 12 & 15 \\
\hline & Total Perolehan Skor & \multicolumn{5}{|c|}{50} \\
\hline & Persentase Pelaksanaan Mengajar Guru & \multicolumn{5}{|c|}{$66,67 \%$} \\
\hline
\end{tabular}




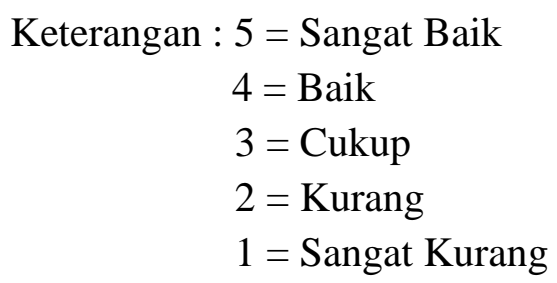
Persentase Pelaksanaan Kegiatan MengajarGuru $=\frac{\text { total perolehan skor X }}{\text { ckor NakciNas }} 100 \%$ $=\frac{50}{75} \times 100 \%=66,67 \%$

Makassar, 25 Juli 2018

Observer

Guru Kelas V

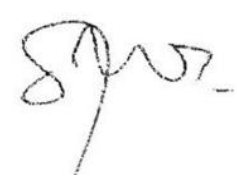

Nashrullah, S.Pd

NIP. 198702142011011009 


\section{Lampiran 13}

\section{HASIL OBSERVASI KEGIATAN BELAJAR SISWA SIKLUS I PERTEMUAN KE-3}

$\begin{array}{ll}\text { Mata Pelajaran } & \text { : Matematika } \\ \text { Materi Pokok } & \text { : Operasi Hitung Bilangan Bulat } \\ \text { Nama Peneliti } & \text { : Siti Nurfaidah } \\ \text { Hari/Tanggal } & \text { : Rabu/ 25 Juli 2018 }\end{array}$

Petunjuk : Berilah tanda centang $(\sqrt{ })$ pada kolom tersedia sesuai dengan pengamatan anda pada saat guru/pebeliti melaksanakan pembelajaran.

\begin{tabular}{|c|c|c|c|c|c|c|}
\hline \multirow{2}{*}{ No } & \multirow{2}{*}{ Aktivitas yang diamati } & \multicolumn{5}{|c|}{ Skor } \\
\hline & & 1 & 2 & 3 & 4 & 5 \\
\hline 1 & Menjawab salam . & & & & & $\sqrt{ }$ \\
\hline 2 & Bersiap untuk mengikuti pembelajaran. & & & & & $\sqrt{ }$ \\
\hline 3 & Melaksanakan berdoa. & & & & & $\sqrt{ }$ \\
\hline 4 & $\begin{array}{l}\text { Mendengarkan tujuan pembelajaran yang } \\
\text { disampaikan guru. }\end{array}$ & & & & $\sqrt{ }$ & \\
\hline 5 & Siswa memperhatikan penjelasan guru. & & & $\sqrt{ }$ & & \\
\hline 6 & Siswa menyiapkan peralatan belajar. & & & & $\sqrt{ }$ & \\
\hline 7 & $\begin{array}{l}\text { Melakukan pengumpulan informasi dari yang sudah } \\
\text { di jelaskan guru. }\end{array}$ & & $\sqrt{ }$ & & & \\
\hline 8 & $\begin{array}{l}\text { Siswa duduk sesuai kelompok yang sudah dibagi } \\
\text { guru. }\end{array}$ & & & $\sqrt{ }$ & & \\
\hline 9 & $\begin{array}{l}\text { Siswa melakukan kegiatan diskusi yang dibimbing } \\
\text { guru. }\end{array}$ & & $\sqrt{ }$ & & & \\
\hline 10 & Siswa bekerja sama dengan teman kelompok. & & $\sqrt{ }$ & & & \\
\hline 11 & Siswa mempresentasikan hasil diskusinya. & & & $\sqrt{ }$ & & \\
\hline 12 & Siswa melaksanakan test dan evalusi dari guru & & & $\sqrt{ }$ & & \\
\hline 13 & Siswa melakukan tanya jawab dengan guru & & & $\sqrt{ }$ & & \\
\hline 14 & Menyimpulkan hasil diskusi dan pembelajaran. & & & $\sqrt{ }$ & & \\
\hline 15 & Melakukan refleksi bersama guru & & $\sqrt{ }$ & & & \\
\hline \multirow{2}{*}{\multicolumn{2}{|c|}{ Jumlah }} & 0 & 4 & 6 & 2 & 3 \\
\hline & & 0 & 8 & 18 & 8 & 15 \\
\hline & Total Perolehan Skor & \multicolumn{5}{|c|}{49} \\
\hline & Persentase Kegiatan Belajar Siswa & \multicolumn{5}{|c|}{$65,33 \%$} \\
\hline
\end{tabular}




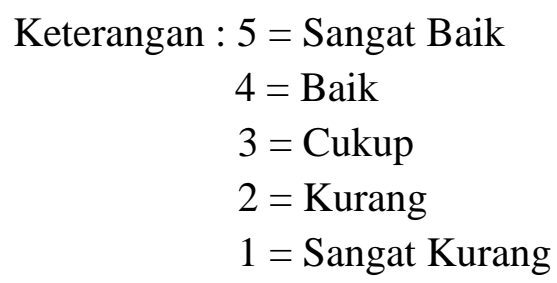

Persentase Kegiatan Belajar Siswa $=\frac{\text { total perolehan skor X }}{\text { ckor NakciNaS }} 100 \%$

$$
=\frac{49}{75} \times 100 \%=65,33 \%
$$

Makassar, 25 Juli 2018

Observer

Guru Kelas V

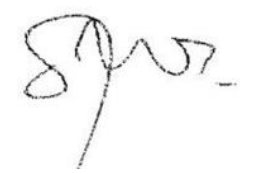

\section{Nashrullah, S.Pd}

NIP. 198702142011011009 


\section{Lampiran 14}

\section{EVALUASI (TES FORMATIF)}

\section{SIKLUS I}

\section{SOAL}

1. Gambarlah garis bilangan beserta keterangannya!

2. Hitunglah hasil dari penjumlahan dan pengurangan bilangan bulat dibawah ini
a. $-9+(-12)=$
b. $6+(-4)=$
c. $4-11=$
d. $-12-(-8)=$

\section{RAMBU-RAMBU JAWABAN}

1. -Semakin ke kanan nilai bilangan semakin besar

-Semakin ke kiri nilai bilangan semakin kecil

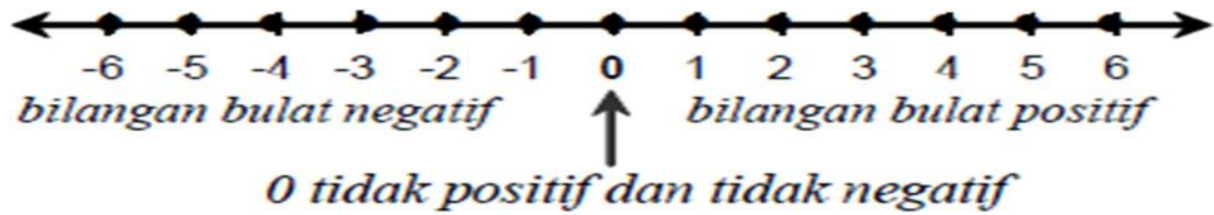

2. a. $-9+(-12)=-21$

b. $6+(-4)=2$

c. $4-11=-7$

d. $-12-(-8)=-4$ 


\section{PEDOMAN PENSKORAN}

- Soal nomor 1 (skor 20)

- Skor 20, jika menggambarkan garis bilangan beserta keterangan dengan benar

- Skor 10, jika menggambarkan garis bilangan beserta keterangan tapi kurang benar.

- Skor 5, jika jawaban kurang benar.

- Skor 0, jika jawaban salah/tidak menjawab sama sekali.

- Soal nomor 2 (skor 80$)$

- Skor 20, jika menjawab dengan benar.

- Skor 10, jika menjawab tapi kurang benar.

- Skor 0, jika jawaban salah/tidak menjawab sama sekali.

Nilai

$$
=\frac{\text { Skor Perolehan }}{\text { Skor Maksimal }} \times 100 \%
$$




\section{Lampiran 15}

\section{PEROLEHAN SKOR EVALUASI (TES FORMATIF)}

SIKLUS I

\begin{tabular}{|c|c|c|c|c|c|}
\hline \multirow[t]{2}{*}{ No. } & \multirow[t]{2}{*}{ Nama Siswa } & \multicolumn{2}{|c|}{$\begin{array}{c}\text { Nomor } \\
\text { Soal/Skor }\end{array}$} & \multirow{2}{*}{$\begin{array}{c}\text { Jumlah } \\
\text { Skor }\end{array}$} & \multirow[t]{2}{*}{ Keterangan } \\
\hline & & $1 / 20$ & $2 / 80$ & & \\
\hline 1. & Denzel & 5 & 45 & 45 & Tidak Tuntas \\
\hline 2. & Muh. Henson & 15 & 50 & 65 & Tidak Tuntas \\
\hline 3. & Katara & 10 & 55 & 65 & Tidak Tuntas \\
\hline 4. & A. Alfatia Alya R & 5 & 60 & 65 & Tidak Tuntas \\
\hline 5. & Ayu Permata Sari & 5 & 50 & 55 & Tidak Tuntas \\
\hline 6. & Andy Ryan Mahendra & 10 & 50 & 60 & Tidak Tuntas \\
\hline 7. & A. Nur Azizah & 5 & 50 & 55 & Tidak Tuntas \\
\hline 8. & Aurellia D.V & 20 & 50 & 70 & Tuntas \\
\hline 9. & A.Nur Asmaul & 20 & 50 & 70 & Tuntas \\
\hline 10. & Abyan & 20 & 55 & 75 & Tuntas \\
\hline 11. & Muh. Fahri & 5 & 40 & 45 & Tidak Tuntas \\
\hline 12. & Nur Hikmah Nurdin & 20 & 55 & 75 & Tuntas \\
\hline 13 & Nabila Alya & 20 & 50 & 70 & Tuntas \\
\hline 14 & Nur Aisyah & 15 & 60 & 75 & Tuntas \\
\hline 15 & Alfira Maharani & 15 & 60 & 75 & Tuntas \\
\hline 16 & Ainal Syahputra & 15 & 60 & 75 & Tuntas \\
\hline 17 & Humaira Natasha & 20 & 50 & 70 & Tuntas \\
\hline 18 & Al Ifti Nur Wasisah & 15 & 55 & 70 & Tuntas \\
\hline 19 & Nur Syafika Apriliyani & 10 & 65 & 75 & Tuntas \\
\hline 20 & Rasya & 10 & 65 & 75 & Tuntas \\
\hline 21 & Asnidar Tri Barata & 15 & 55 & 70 & Tuntas \\
\hline 22 & Afgan Dulfian & 5 & 50 & 55 & Tidak Tuntas \\
\hline 23 & Ghulam Sultan Dafi & 10 & 30 & 40 & Tidak Tuntas \\
\hline 24 & Dwi Yana Aulia & 10 & 40 & 50 & Tidak Tuntas \\
\hline 25 & Nur Aristia Aprilia & 5 & 40 & 45 & Tidak Tuntas \\
\hline
\end{tabular}




\begin{tabular}{|c|c|c|c|c|c|}
\hline \multirow{2}{*}{ No. } & \multirow{2}{*}{ Nama Siswa } & \multicolumn{2}{|c|}{$\begin{array}{c}\text { Nomor } \\
\text { Soal/Skor }\end{array}$} & \multirow{2}{*}{$\begin{array}{c}\text { Jumlah } \\
\text { Skor }\end{array}$} & \multirow{2}{*}{ Keterangan } \\
\hline & & $1 / 20$ & $2 / 80$ & & \\
\hline 26 & Annisa Zaharani & 15 & 60 & 75 & Tuntas \\
\hline 27 & Arham Syahputra & 10 & 65 & 75 & Tuntas \\
\hline 28 & Nurjannah A.S & 10 & 60 & 70 & Tuntas \\
\hline 29 & Fitri Dwi Handayani & 5 & 60 & 65 & Tidak Tuntas \\
\hline 30 & Muh. Farel & 5 & 60 & 65 & Tidak Tuntas \\
\hline \multicolumn{4}{|c|}{ Jumlah } & 1940 & \multirow{3}{*}{$\begin{array}{l}\text { Tuntas } \\
\text { (Cukup) }\end{array}$} \\
\hline \multicolumn{4}{|c|}{ Rata-rata } & 64,67 & \\
\hline \multicolumn{4}{|c|}{ Persentase Ketuntasan Belajar } & $53,33 \%$ & \\
\hline
\end{tabular}

Rata-rata

$$
=\frac{\text { Jumlah skor }}{\text { Jumlah siswa keseluruhan }}=\frac{1940}{30}=64,67
$$

Persentase Ketuntasan Belajar $=\frac{\text { Jumah siswa yang tuntas }}{\text { Jumlah siswakeseluruhan }} \times 100 \%=\frac{16}{30} \times 100 \%$

$$
=53,33 \%
$$


Lampiran 16

\section{RENCANA PELAKSANAAN PEMBELAJARAN (RPP) \\ SIKLUS II PERTEMUAN KE-1}

$\begin{array}{ll}\text { Satuan Pendidikan } & \text { : SD Inpres Perumnas Antang II/I } \\ \text { Kelas/ Semester } & \text { : V/I } \\ \text { Hari/Tanggal } & \text { : Senin / 30 Juli } 2018 \\ \text { Mata Pelajaran } & \text { : Matematika } \\ \text { Alokasi Waktu } & : 3 \text { X } 35 \text { Menit }\end{array}$

A. Standar Kompetensi

2. Melakukan operasi hitung bilangan bulat dalam pemecahan masalah

\section{B. Kompetensi Dasar}

2.1 Melakukan operasi hitung bilangan bulat termasuk penggunaan sifat sifatnya, pembulatan dan penaksiran

C. Indikator

1. Menghitung hasil pengurangan bilangan bulat tanpa menggunakan garis bilangan

2. Menghitung hasil perkalian bilangan bulat

D. Tujuan Pembelajaran

1. Siswa dapat, menghitung hasil pengurangan bilangan bulat tanpa menggunakan garis bilangan

2. Siswa dapat, menghitung hasil perkalian bilangan bulat

Karakter siswa yang diharapkan : Disiplin (Discipline), Rasa hormat

dan perhatian (respect), Tekun (diligence) dan Tanggung jawab (responsibility)

E. Materi Pembelajaran

Operasi hitung bilangan bulat

F. Model dan Metode Pembelajaran

1. Model : Auditory, Intellectually, Repetition (AIR)

2. Metode : Ceramah, tanya jawab, demonstrasi, diskusi penugasan

G. Sumber Belajar

1. Silabus dan KTSP 2006 Mata Pelajaran Matematika

2. Ali Masykur, dkk, 2016, Senang Belajar Matematika kelas V, Jakarta: Yudhistira 


\section{H. Kegiatan Pembelajaran}

\begin{tabular}{|l|c|}
\hline \multicolumn{1}{|c|}{ Kegiatan Pembelajaran } & Waktu \\
\hline D. Kegiatan Awal & 10 menit \\
1. Salam pembuka & (Klasikal) \\
2. Mengecek kebersihan kelas & (Klasikal) \\
3. Berdoa & (Klasikal) \\
4. Mengisi daftar hadir & (Klasikal) \\
5. Apersepsi melalui sesi tanya jawab & (Klasikal) \\
6. Menyampaikan tujuan pembelajaran & 70 menit \\
\hline E. Kegiatan Inti & (Klasikal) \\
Tahap Auditory & \\
7. Guru membagi siswa menjadi beberapa kelompok & (Klasikal) \\
kecil & (Klasikal) \\
8. Guru memberikan LKS kepada siswa untuk & \\
9. Guru memberi kesempatan kepada siswa untuk & \\
bertanya mengenai soal LKS yang kurang dipahami & (Klasikal) \\
Tahap Intellectually & (Kelompok) \\
10.Guru membimbing kelompok belajar siswa untuk \\
berdiskusi dengan teman dalam satu kelompok \\
sehingga dapat menyelesaikan LKS
\end{tabular}

\section{Penilaian}
3. Teknik Penilaian
: Tes tertulis

4. Instrumen Penilaian

: Isian 


\section{J. Daftar Pustaka}

Ali Masykur, dkk, 2016, Senang Belajar Matematika kelas V, Jakarta: Yudhistira

Makassar, 30 Juli 2018

Guru Kelas V

Peneliti

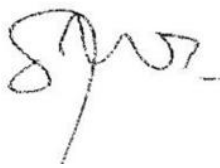

Nashrullah, S.Pd

Siti Nurfaidah

NIP. 198702142011011009

NIM: 093188793041

Mengetahui

Kepala SD Inpres Perumnas Antang II/I

$$
\text { Suharniati, S.Pd }
$$

NIP 196607091988032011 
Lampiran 17

\section{LEMBAR KERJA SISWA (LKS) \\ SIKLUS II PERTEMUAN KE-1}

\begin{tabular}{|c|c|}
\hline Mata Pelajaran & : Mat \\
\hline Kelas/ Semester & $: \mathrm{V} / \mathrm{I}$ \\
\hline Hari/Tanggal & : Seni \\
\hline Kelompok & : \\
\hline Nama Anggota Kelompok & : \\
\hline 1. .. & ...... \\
\hline 2. & \\
\hline 3. . & $\ldots \ldots$ \\
\hline 4. & \\
\hline & \\
\hline
\end{tabular}

Kompetensi Dasar $\quad$ : 1.1 Melakukan operasi hitung bilangan bulat termasuk penggunaan sifat-sifatnya, pembulatan dan penaksiran

Tujuan Pembelajaran : 1. Siswa dapat, menghitung hasil pengurangan bilangan bulat tanpa menggunakan garis bilangan

2. Siswa dapat menghitung hasil perkalian bilangan bulat

Langkah-langkah kegiatan :

a. Kerjakanlah soal-soal berikut ini bersama teman kelompokmu.

b. Jawablah soal-soal berikut dengan benar. 


\section{Soal!}

1. $-14-7=$ 6. $-12 \times(-5)=$

2. $5-(-16)=\quad 7.6 \times 10=$
3. $(-18)-(-9)=$
8. $12 \times(-10)=$

4. $-2-34=$

9. $-14 \times 7=$

5. $-10-17=$

10. $-5 \times 21=$

\section{PEDOMAN PENSKORAN}

- Soal nomor 1-10 (masing-masing skor 10$)$, skor maksimal $=100$

- Skor 10, jika jawaban benar.

- Skor 5, jika jawaban kurang benar.

- Skor 0, jika jawaban salah/tidak menjawab sama sekali.

Nilai

$$
=\frac{\text { Skor Perolehan }}{\text { Skor Maksimal }} \times 100 \%
$$


Lampiran 18

PEROLEHAN SKOR LKS

SIKLUS II PERTEMUAN KE-1

\begin{tabular}{|c|c|c|c|c|c|}
\hline $\begin{array}{c}\text { No } \\
\text {. }\end{array}$ & Kelompok & Nama Siswa & $\begin{array}{c}\text { Jumlah } \\
\text { Skor }\end{array}$ & Nilai & Keterangan \\
\hline 1 & 1 & $\begin{array}{ll}\text { 1. } & \text { Andi Nur Asmaul } \\
\text { 2. } & \text { Ainal Basri Syahputra } \\
\text { 3. } & \text { Muh. Henson } \\
\text { 4. } & \text { Alfira Maharani } \\
\text { 5. } & \text { Nur Aristin Aprilia }\end{array}$ & 60 & 60 & $\begin{array}{l}\text { Tidak } \\
\text { Tuntas }\end{array}$ \\
\hline 2 & 2 & $\begin{array}{l}\text { 1. Al-Ifti Nur Wasisah } \\
\text { 2. Nabila Alya } \\
\text { 3. A. Nur Azizah } \\
\text { 4. Muh. Fahri } \\
\end{array}$ & 65 & 65 & $\begin{array}{l}\text { Tidak } \\
\text { Tuntas }\end{array}$ \\
\hline 3 & 3 & $\begin{array}{l}\text { 1. Ayu Permata Sari } \\
\text { 2. Aurellia D.V } \\
\text { 3. Andi Ryan } \\
\text { 4. Annisa Zaharani } \\
\text { 5. Rasya }\end{array}$ & 60 & 60 & $\begin{array}{l}\text { Tidak } \\
\text { Tuntas }\end{array}$ \\
\hline 4 & 4 & $\begin{array}{l}\text { 1. A. Alfatia Alya } \\
\text { 2. Nursyafika Apriliyani } \\
\text { 3. Afgan Dulfian } \\
\text { 4. Asnidar Tri Brata } \\
\text { 5. Katara }\end{array}$ & 85 & 85 & Tuntas \\
\hline 5 & 5 & $\begin{array}{l}\text { 1. Nur Aisyah } \\
\text { 2. Dwi Yana Aulia } \\
\text { 3. Fitri Dwi Handayani } \\
\text { 4. Abyan } \\
\text { 5. Arham Syahputra }\end{array}$ & 80 & 80 & Tuntas \\
\hline 6 & 6 & $\begin{array}{ll}\text { 1. } & \text { Humaira Natasha } \\
\text { 2. } & \text { Denzel } \\
\text { 3. } & \text { Nur Jannah } \\
\text { 4. Nur Hikmah Nurdin } \\
\text { 5. } & \text { Ghulam Sultan Dafi } \\
\end{array}$ & 90 & 90 & Tuntas \\
\hline \multicolumn{3}{|c|}{ Jumlah } & 440 & 440 & \multirow[t]{2}{*}{ Tuntas } \\
\hline \multicolumn{3}{|c|}{ Rata-rata } & 73,33 & 73,33 & \\
\hline
\end{tabular}

Nilai KKM

$: \geq 70$

Rata-rata

$=\frac{\text { Jumlah Skor }}{\text { Jumlah Kelompok }}=\frac{440}{6}=73,33$ 


\section{Lampiran 19}

\section{HASIL OBSERVASI KEGIATAN MENGAJAR GURU SIKLUS II PERTEMUAN KE-1}

$\begin{array}{ll}\text { Mata Pelajaran } & \text { : Matematika } \\ \text { Materi Pokok } & \text { : Operasi Hitung Bilangan Bulat } \\ \text { Nama Peneliti } & \text { : Siti Nurfaidah } \\ \text { Hari/Tanggal } & \text { : Senin/ 30 Juli } 2018\end{array}$

Petunjuk : Berilah tanda centang $(\sqrt{ })$ pada kolom tersedia sesuai dengan pengamatan anda pada saat guru/peneliti melaksanakan pembelajaran.

\begin{tabular}{|c|c|c|c|c|c|c|}
\hline \multirow{2}{*}{ No } & \multirow{2}{*}{ Aktivitas yang diamati } & \multicolumn{5}{|c|}{ Skor } \\
\hline & & 1 & 2 & 3 & 4 & 5 \\
\hline 1 & Membuka pembelajaran dan mengucap salam & & & & & $\sqrt{ }$ \\
\hline 2 & $\begin{array}{l}\text { Mengkondisikan ruang kelas dan mempersiapkan } \\
\text { siswa untuk mengikuti pembelajaran. }\end{array}$ & & & & $\sqrt{ }$ & \\
\hline 3 & Mengajak siswa berdoa. & & & & & $\sqrt{ }$ \\
\hline 4 & Menyampaikan tujuan pembelajaran. & & & & & $\sqrt{ }$ \\
\hline 5 & Memberikan motivasi dan merumuskan masalah. & & & $\sqrt{ }$ & & \\
\hline 6 & Menyiapkan bahan ajar. & & & & $\sqrt{ }$ & \\
\hline 7 & $\begin{array}{l}\text { Membimbing siswa untuk mengumpulkan sebuah } \\
\text { informasi, }\end{array}$ & & $\sqrt{ }$ & & & \\
\hline 8 & Membagi kelompok diskusi. & & & & $\sqrt{ }$ & \\
\hline 9 & $\begin{array}{l}\text { Memimpin jalannya diskusi dan membimbing } \\
\text { kelompok diskusi }\end{array}$ & & & & $\sqrt{ }$ & \\
\hline 10 & $\begin{array}{l}\text { Menjelaskan tentang materi yang telah didiskusikan } \\
\text { dan melakukan timbal balik. }\end{array}$ & & $\sqrt{ }$ & & & \\
\hline 11 & Membimbing siswa untuk membuat kesimpulan. & & $\sqrt{ }$ & & & \\
\hline 12 & Memberikan test dan evaluasi & & & $\sqrt{ }$ & & \\
\hline 13 & Memberikan siswa kesempatan untuk bertanya. & & & $\sqrt{ }$ & & \\
\hline 14 & Membuat kesimpulan bersama siswa. & & & $\sqrt{ }$ & & \\
\hline 15 & Melaukan refleksi bersama dengan siswa. & & & $\sqrt{ }$ & & \\
\hline \multirow{2}{*}{\multicolumn{2}{|c|}{ Jumlah }} & 0 & 3 & 5 & 4 & 3 \\
\hline & & 0 & 6 & 15 & 16 & 15 \\
\hline & Total Perolehan Skor & \multicolumn{5}{|c|}{52} \\
\hline & Persentase Pelaksanaan Mengajar Guru & \multicolumn{5}{|c|}{$69,33 \%$} \\
\hline
\end{tabular}




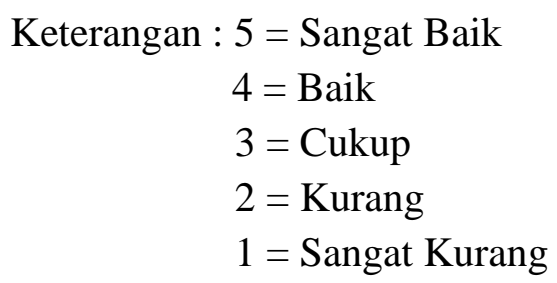
Persentase Pelaksanaan Kegiatan MengajarGuru $=\frac{\text { total perolehan skor X }}{\text { ckor NakciNas }} 100 \%$ $=\frac{52}{75} \times 100 \%=69,33 \%$

Makassar, 30 Juli 2018

Observer

Guru Kelas V

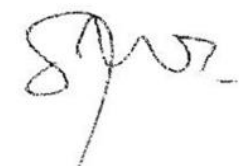

Nashrullah, S.Pd

NIP. 198702142011011009 


\section{Lampiran 20}

\section{HASIL OBSERVASI KEGIATAN BELAJAR SISWA SIKLUS II PERTEMUAN KE-1}

$\begin{array}{ll}\text { Mata Pelajaran } & \text { : Matematika } \\ \text { Materi Pokok } & \text { : Operasi Hitung Bilangan Bulat } \\ \text { Nama Peneliti } & \text { : Siti Nurfaidah } \\ \text { Hari/Tanggal } & \text { : Senin/ 30 Juli 2018 }\end{array}$

Petunjuk : Berilah tanda centang $(\sqrt{ })$ pada kolom tersedia sesuai dengan pengamatan anda pada saat guru/pebeliti melaksanakan pembelajaran.

\begin{tabular}{|c|c|c|c|c|c|c|}
\hline \multirow{2}{*}{ No } & \multirow{2}{*}{ Aktivitas yang diamati } & \multicolumn{5}{|c|}{ Skor } \\
\hline & & 1 & 2 & 3 & 4 & 5 \\
\hline 1 & Menjawab salam. & & & & & $\sqrt{ }$ \\
\hline 2 & Bersiap untuk mengikuti pembelajaran. & & & & & $\sqrt{ }$ \\
\hline 3 & Melaksanakan berdoa. & & & & & $\sqrt{ }$ \\
\hline 4 & $\begin{array}{l}\text { Mendengarkan tujuan pembelajaran yang } \\
\text { disampaikan guru. }\end{array}$ & & & & $\sqrt{ }$ & \\
\hline 5 & Siswa memperhatikan penjelasan guru. & & & $\sqrt{ }$ & & \\
\hline 6 & Siswa menyiapkan peralatan belajar. & & & $\sqrt{ }$ & & \\
\hline 7 & $\begin{array}{l}\text { Melakukan pengumpulan informasi dari yang sudah } \\
\text { di jelaskan guru. }\end{array}$ & & $\sqrt{ }$ & & & \\
\hline 8 & $\begin{array}{l}\text { Siswa duduk sesuai kelompok yang sudah dibagi } \\
\text { guru. }\end{array}$ & & & & $\sqrt{ }$ & \\
\hline 9 & $\begin{array}{l}\text { Siswa melakukan kegiatan diskusi yang dibimbing } \\
\text { guru. }\end{array}$ & & & $\sqrt{ }$ & & \\
\hline 10 & Siswa bekerja sama dengan teman kelompok. & & & $\sqrt{ }$ & & \\
\hline 11 & Siswa mempresentasikan hasil diskusinya. & & & & $\sqrt{ }$ & \\
\hline 12 & Siswa melaksanakan test dan evalusi dari guru & & & $\sqrt{ }$ & & \\
\hline 13 & Siswa melakukan tanya jawab dengan guru & & & $\sqrt{ }$ & & \\
\hline 14 & Menyimpulkan hasil diskusi dan pembelajaran. & & $\sqrt{ }$ & & & \\
\hline 15 & Melakukan refleksi bersama guru & & $\sqrt{ }$ & & & \\
\hline \multirow{2}{*}{\multicolumn{2}{|c|}{ Jumlah }} & 0 & 3 & 6 & 3 & 3 \\
\hline & & 0 & 6 & 18 & 12 & 15 \\
\hline & Total Perolehan Skor & \multicolumn{5}{|c|}{51} \\
\hline & Persentase Kegiatan Belajar Siswa & \multicolumn{5}{|c|}{$68 \%$} \\
\hline
\end{tabular}


Keterangan : $5=$ Sangat Baik

$$
\begin{aligned}
& 4=\text { Baik } \\
& 3=\text { Cukup } \\
& 2=\text { Kurang } \\
& 1=\text { Sangat Kurang }
\end{aligned}
$$

Persentase Kegiatan Belajar Siswa $=\frac{\text { total perolehan skor X }}{\text { ckor NakciNaS }} 100 \%$

$$
=\frac{51}{75} \times 100 \%=68 \%
$$

Makassar, 30 Juli 2018

Observer

Guru Kelas V

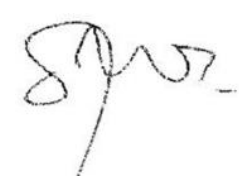

\section{Nashrullah, S.Pd}

NIP. 198702142011011009 
Lampiran 21

\section{RENCANA PELAKSANAAN PEMBELAJARAN (RPP) \\ SIKLUS II PERTEMUAN KE-2}

$\begin{array}{ll}\text { Satuan Pendidikan } & \text { : SD Inpres Perumnas Antang II/I } \\ \text { Kelas/ Semester } & \text { : V/I } \\ \text { Hari/Tanggal } & \text { : Selasa / 31 Juli } 2018 \\ \text { Mata Pelajaran } & \text { : Matematika } \\ \text { Alokasi Waktu } & : 3 \text { X 35 Menit }\end{array}$

A. Standar Kompetensi

2. Melakukan operasi hitung bilangan bulat dalam pemecahan masalah

\section{B. Kompetensi Dasar}

1.2 Melakukan operasi hitung bilangan bulat termasuk penggunaan sifat sifatnya, pembulatan dan penaksiran

C. Indikator

1. Menghitung hasil perkalian bilangan bulat

2. Mengidentifikasi sifat-sifat operasi hitung bilangan bulat

D. Tujuan Pembelajaran

1. Siswa dapat, menghitung hasil perkalian bilangan bulat

2. Siswa dapat, mengidentifikasi sifat-sifat operasi hitung bilangan bulat

Karakter siswa yang diharapkan : Disiplin (Discipline), Rasa hormat

$\begin{array}{lll}\text { dan perhatian } & \text { (respect), } & \text { Tekun } \\ \text { (diligence) dan } & \text { Tanggung } & \text { jawab } \\ \text { (responsibility) } & & \end{array}$

E. Materi Pembelajaran

Operasi hitung bilangan bulat

F. Model dan Metode Pembelajaran

1. Model : Auditory, Intellectually, Repetition (AIR)

2. Metode :Ceramah, tanya jawab, demonstrasi,diskusi dan penugasan

G. Sumber Belajar

1. Silabus dan KTSP 2006 Mata Pelajaran Matematika

2. Ali Masykur, dkk, 2016, Senang Belajar Matematika kelas V, Jakarta: Yudhistira 


\section{H. Kegiatan Pembelajaran}

\begin{tabular}{|c|c|}
\hline Kegiatan Pembelajaran & Waktu \\
\hline $\begin{array}{l}\text { A. Kegiatan Awal } \\
\text { 1. Salam pembuka } \\
\text { 2. Mengecek kebersihan kelas } \\
\text { 3. Berdoa } \\
\text { 4. Mengisi daftar hadir } \\
\text { 5. Apersepsi melalui sesi tanya jawab } \\
\text { 6. Menyampaikan tujuan pembelajaran }\end{array}$ & $\begin{array}{l}15 \text { menit } \\
\text { (Klasikal) } \\
\text { (Klasikal) } \\
\text { (Klasikal) } \\
\text { (Klasikal) } \\
\text { (Klasikal) } \\
\text { (Klasikal) }\end{array}$ \\
\hline $\begin{array}{l}\text { B. Kegiatan Inti } \\
\text { Tahap Auditory } \\
\text { 7. Guru membagi siswa menjadi beberapa kelompok } \\
\text { kecil } \\
\text { 8. Guru memberikan LKS kepada siswa untuk } \\
\text { dikerjakan secara kelompok } \\
\text { 9. Guru memberi kesempatan kepada siswa untuk } \\
\text { bertanya mengenai soal LKS yang kurang dipahami } \\
\text { Tahap Intellectually } \\
\text { 10. Guru membimbing kelompok belajar siswa untuk } \\
\text { berdiskusi dengan teman dalam satu kelompok } \\
\text { sehingga dapat menyelesaikan LKS } \\
\text { 11. Guru memberi kesempatan kepada beberapa } \\
\text { kelompok untuk mempresentasikan hasil kerjanya, } \\
\text { serta memberikan kesempatan kepada kelompok lain } \\
\text { untuk bertanya dan mengemukakan pendapatnya } \\
\text { Tahap Repetition } \\
\text { 12. Guru melakukan pengulangan dengan memberikan } \\
\text { latihan soal atau kuis individu kepada siswa baik } \\
\text { dengan lisan maupun tulisan }\end{array}$ & $\begin{array}{l}\text { (Klasikal) } \\
\text { (Klasikal) }\end{array}$ \\
\hline $\begin{array}{l}\text { C. Kegiatan Akhir } \\
\text { 1. Siswa dibimbing untuk menyimpulkan materi } \\
\text { pembelajaran } \\
\text { 2. Guru memberikan motivasi dan pesan-pesan moral } \\
\text { 3. Membaca doa } \\
\text { 4. Salam penutup }\end{array}$ & $\begin{array}{l}10 \text { menit } \\
\text { (Klasikal) } \\
\text { (Klasikal) } \\
\text { (Klasikal) } \\
\text { (Klasikal) }\end{array}$ \\
\hline
\end{tabular}

\section{Penilaian}

1. Teknik Penilaian

2. Instrumen Penilaian
: Tes tertulis

: Isian 


\section{J. Daftar Pustaka}

Ali Masykur, dkk, 2016, Senang Belajar Matematika kelas V, Jakarta: Yudhistira

Makassar, 31 Juli 2018

Guru Kelas V

Peneliti

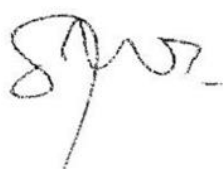

Nashrullah, S.Pd

Siti Nurfaidah

NIP. 198702142011011009

NIM: 093188793041

Mengetahui

Kepala SD Inpres Perumnas Antang II/I

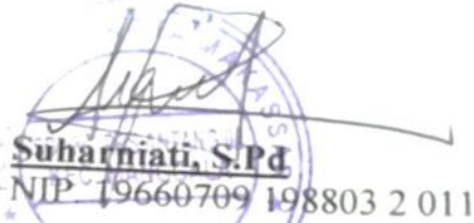


Lampiran 22

\section{LEMBAR KERJA SISWA (LKS) \\ SIKLUS II PERTEMUAN KE-2}

$\begin{array}{ll}\text { Mata Pelajaran } & \text { : Matematika } \\ \text { Kelas/ Semester } & \text { : V/I } \\ \text { Hari/Tanggal } & \text { : Selasa / 31 Juli 2018 }\end{array}$

Kelompok

Nama Anggota Kelompok

1.

2 .

3.

4.

Kompetensi Dasar $\quad$ :1.1 Melakukan operasi hitung bilangan bulat termasuk penggunaan sifat-sifatnya, pembulatan dan penaksiran

Tujuan Pembelajaran : 1. Siswa dapat menghitung perkalian bilangan bulat 2. Siswa dapat mengidentifikasi sifat-sifat operasi hitung bilangan bulat

Langkah-langkah kegiatan :

a. Kerjakanlah soal-soal berikut ini bersama teman kelompokmu.

b. Jawablah soal-soal berikut dengan benar. 


\section{Soal!}

1. Tuliskan sifat-sifat operasi hitung bilangan bula beserta contohnya!

2. $14 \times(-7)=$

3. $-12 \times(-15)=$

4. $-5 \times 16=$

$5.5-11=$

\section{PEDOMAN PENSKORAN}

- Soal nomor 1 (skor 50)

- Soal nomor 2-4 (masing-masing skir 10)

- Skor 10, jika jawaban benar.

- Skor 5, jika jawaban kurang benar

- Skor 0, jika jawaban salah/tidak menjawab sama sekali.

Nilai

$$
=\frac{\text { Skor Perolehan }}{\text { Skor Maksimal }} \times 100 \%
$$


Lampiran 23

PEROLEHAN SKOR LKS

SIKLUS II PERTEMUAN KE-2

\begin{tabular}{|c|c|c|c|c|c|}
\hline $\begin{array}{c}\text { No } \\
\text {. }\end{array}$ & Kelompok & Nama Siswa & $\begin{array}{l}\text { Jumlah } \\
\text { Skor }\end{array}$ & Nilai & Keterangan \\
\hline 1 & 1 & $\begin{array}{l}\text { 1. Asnidar Tri Brata } \\
\text { 2. Humaira Natasha } \\
\text { 3. Denzel } \\
\text { 4. Nur Jannah } \\
\text { 5. Ghulam Sultan Dafi }\end{array}$ & 80 & 80 & Tuntas \\
\hline 2 & 2 & $\begin{array}{l}\text { 1. Abyan } \\
\text { 2. Ainal Basri Syahputra } \\
\text { 3. Nur Aristin Aprilia } \\
\text { 4. Ayu Permata Sari } \\
\text { 5. Annisa Zaharani }\end{array}$ & 80 & 80 & Tuntas \\
\hline 3 & 3 & $\begin{array}{l}\text { 1. Arham Syahputra } \\
\text { 2. Nabila Alya } \\
\text { 3. A. Nur Azizah } \\
\text { 4. Andi Nur Asmaul } \\
\text { 5. Afgan Dulfian }\end{array}$ & 85 & 85 & Tuntas \\
\hline 4 & 4 & $\begin{array}{ll}\text { 1. } & \text { Al-Ifti Nur Wasisah } \\
\text { 2. Muh. Fahri } \\
\text { 3. Dwi Yana Aulia } \\
\text { 4. Fitri Dwi Handayani } \\
\text { 5. Rasya }\end{array}$ & 65 & 65 & $\begin{array}{l}\text { Tidak } \\
\text { Tuntas }\end{array}$ \\
\hline 5 & 5 & $\begin{array}{l}\text { 1. Nur Hikmah Nurdin } \\
\text { 2. Muh. Henson } \\
\text { 3. Alfira Maharani } \\
\text { 4. Nursyafika Apriliyani } \\
\text { 5. Andi Ryan }\end{array}$ & 100 & 100 & Tuntas \\
\hline 6 & 6 & $\begin{array}{ll}\text { 1. } & \text { Aurellia D.V } \\
\text { 2. A. Alfatia Alya } \\
\text { 3. Nur Aisyah } \\
\text { 4. } \text { Katara } \\
\end{array}$ & 75 & 75 & Tuntas \\
\hline \multicolumn{3}{|c|}{ Jumlah } & 485 & 485 & \multirow{2}{*}{ Tuntas } \\
\hline Rata & & & 80,83 & 80,83 & \\
\hline
\end{tabular}

Nilai KKM

$: \geq 70$

Rata-rata

$=\frac{\text { Jumlah Skor }}{\text { Jumlah Kelompok }}=\frac{485}{6}=80,83$ 


\section{Lampiran 24}

\section{HASIL OBSERVASI KEGIATAN MENGAJAR GURU SIKLUS II PERTEMUAN KE-2}

$\begin{array}{ll}\text { Mata Pelajaran } & \text { : Matematika } \\ \text { Materi Pokok } & \text { : Operasi Hitung Bilangan Bulat } \\ \text { Nama Peneliti } & \text { : Siti Nurfaidah } \\ \text { Hari/Tanggal } & \text { : Selasa/ 31 Juli 2018 }\end{array}$

Petunjuk : Berilah tanda centang $(\sqrt{ })$ pada kolom tersedia sesuai dengan pengamatan anda pada saat guru/peneliti melaksanakan pembelajaran.

\begin{tabular}{|c|c|c|c|c|c|c|}
\hline \multirow{2}{*}{ No } & \multirow{2}{*}{ Aktivitas yang diamati } & \multicolumn{5}{|c|}{ Skor } \\
\hline & & 1 & 2 & 3 & 4 & 5 \\
\hline 1 & Membuka pembelajaran dan mengucap salam & & & & & $\sqrt{ }$ \\
\hline 2 & $\begin{array}{l}\text { Mengkondisikan ruang kelas dan mempersiapkan } \\
\text { siswa untuk mengikuti pembelajaran. }\end{array}$ & & & & & $\sqrt{ }$ \\
\hline 3 & Mengajak siswa berdoa. & & & & & $\sqrt{ }$ \\
\hline 4 & Menyampaikan tujuan pembelajaran. & & & & & $\sqrt{ }$ \\
\hline 5 & Memberikan motivasi dan merumuskan masalah. & & & & $\sqrt{ }$ & \\
\hline 6 & Menyiapkan bahan ajar. & & & & $\sqrt{ }$ & \\
\hline 7 & $\begin{array}{l}\text { Membimbing siswa untuk mengumpulkan sebuah } \\
\text { informasi, }\end{array}$ & & & $\sqrt{ }$ & & \\
\hline 8 & Membagi kelompok diskusi. & & & & $\sqrt{ }$ & \\
\hline 9 & $\begin{array}{l}\text { Memimpin jalannya diskusi dan membimbing } \\
\text { kelompok diskusi }\end{array}$ & & & $\sqrt{ }$ & & \\
\hline 10 & $\begin{array}{l}\text { Menjelaskan tentang materi yang telah didiskusikan } \\
\text { dan melakukan timbal balik. }\end{array}$ & & & $\sqrt{ }$ & & \\
\hline 11 & Membimbing siswa untuk membuat kesimpulan. & & & & $\sqrt{ }$ & \\
\hline 12 & Memberikan test dan evaluasi & & & $\sqrt{ }$ & & \\
\hline 13 & Memberikan siswa kesempatan untuk bertanya. & & & & $\sqrt{ }$ & \\
\hline 14 & Membuat kesimpulan bersama siswa. & & & & $\sqrt{ }$ & \\
\hline 15 & Melaukan refleksi bersama dengan siswa. & & & $\sqrt{ }$ & & \\
\hline \multirow{2}{*}{\multicolumn{2}{|c|}{ Jumlah }} & 0 & 0 & 5 & 6 & 4 \\
\hline & & 0 & 0 & 15 & 24 & 20 \\
\hline & Total Perolehan Skor & \multicolumn{5}{|c|}{59} \\
\hline & Persentase Pelaksanaan Mengajar Guru & \multicolumn{5}{|c|}{$78,67 \%$} \\
\hline
\end{tabular}




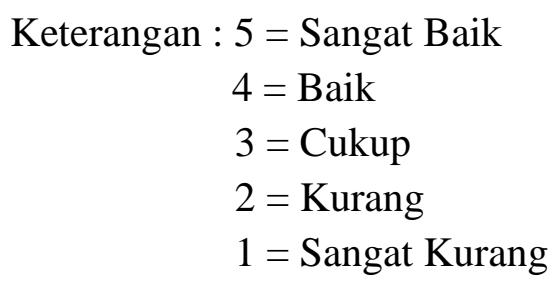

Persentase Pelaksanaan Kegiatan Mengajar Guru $=\frac{\text { total perolehan skor X }}{\text { ckor NakciNaS }} 100 \%$

$=\frac{59}{75} \times 100 \%=78,67 \%$

Makassar, 31 Juli 2018

Observer

Guru Kelas V

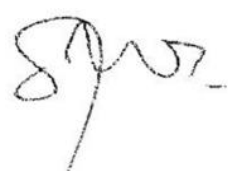

Nashrullah, S.Pd

NIP. 198702142011011009 


\section{Lampiran 25}

\section{HASIL OBSERVASI KEGIATAN BELAJAR SISWA SIKLUS II PERTEMUAN KE-2}

$\begin{array}{ll}\text { Mata Pelajaran } & \text { : Matematika } \\ \text { Materi Pokok } & \text { : Operasi Hitung Bilangan Bulat } \\ \text { Nama Peneliti } & \text { : Siti Nurfaidah } \\ \text { Hari/Tanggal } & \text { : Selasa/ 31 Juli 2018 }\end{array}$

Petunjuk : Berilah tanda centang $(\sqrt{ })$ pada kolom tersedia sesuai dengan pengamatan anda pada saat guru/pebeliti melaksanakan pembelajaran.

\begin{tabular}{|c|c|c|c|c|c|c|}
\hline \multirow{2}{*}{ No } & \multirow{2}{*}{ Aktivitas yang diamati } & \multicolumn{5}{|c|}{ Skor } \\
\hline & & 1 & 2 & 3 & 4 & 5 \\
\hline 1 & Menjawab salam . & & & & & $\sqrt{ }$ \\
\hline 2 & Bersiap untuk mengikuti pembelajaran. & & & & & $\sqrt{ }$ \\
\hline 3 & Melaksanakan berdoa. & & & & & $\sqrt{ }$ \\
\hline 4 & $\begin{array}{l}\text { Mendengarkan tujuan pembelajaran yang } \\
\text { disampaikan guru. }\end{array}$ & & & & $\sqrt{ }$ & \\
\hline 5 & Siswa memperhatikan penjelasan guru. & & & & $\sqrt{ }$ & \\
\hline 6 & Siswa menyiapkan peralatan belajar. & & & & $\sqrt{ }$ & \\
\hline 7 & $\begin{array}{l}\text { Melakukan pengumpulan informasi dari yang sudah } \\
\text { di jelaskan guru. }\end{array}$ & & & $\sqrt{ }$ & & \\
\hline 8 & $\begin{array}{l}\text { Siswa duduk sesuai kelompok yang sudah dibagi } \\
\text { guru. }\end{array}$ & & & & $\sqrt{ }$ & \\
\hline 9 & $\begin{array}{l}\text { Siswa melakukan kegiatan diskusi yang dibimbing } \\
\text { guru. }\end{array}$ & & & & $\sqrt{ }$ & \\
\hline 10 & Siswa bekerja sama dengan teman kelompok. & & & & $\sqrt{ }$ & \\
\hline 11 & Siswa mempresentasikan hasil diskusinya. & & & & $\sqrt{ }$ & \\
\hline 12 & Siswa melaksanakan test dan evalusi dari guru & & & $\sqrt{ }$ & & \\
\hline 13 & Siswa melakukan tanya jawab dengan guru & & & $\sqrt{ }$ & & \\
\hline 14 & Menyimpulkan hasil diskusi dan pembelajaran. & & & $\sqrt{ }$ & & \\
\hline 15 & Melakukan refleksi bersama guru & & & $\sqrt{ }$ & & \\
\hline \multirow{2}{*}{\multicolumn{2}{|c|}{ Jumlah }} & 0 & 0 & 5 & 7 & 3 \\
\hline & & 0 & 0 & 15 & 28 & 15 \\
\hline & Total Perolehan Skor & \multicolumn{5}{|c|}{58} \\
\hline & Persentase Kegiatan Belajar Siswa & \multicolumn{5}{|c|}{$77,33 \%$} \\
\hline
\end{tabular}


Keterangan : $5=$ Sangat Baik

$$
\begin{aligned}
& 4=\text { Baik } \\
& 3=\text { Cukup } \\
& 2=\text { Kurang } \\
& 1=\text { Sangat Kurang }
\end{aligned}
$$

Persentase Kegiatan Belajar Siswa $=\frac{\text { total perolehan skor X }}{\text { ckor NakciNaS }} 100 \%$

$$
=\frac{58}{75} \times 100 \%=77,33 \%
$$

Makassar, 31 Juli 2018

Observer

Guru Kelas V

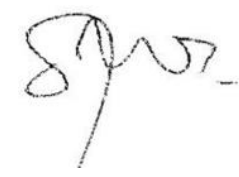

Nashrullah, S.Pd

NIP. 198702142011011009 
Lampiran 26

\section{RENCANA PELAKSANAAN PEMBELAJARAN (RPP) \\ SIKLUS II PERTEMUAN KE-3}

$\begin{array}{ll}\text { Satuan Pendidikan } & \text { : SD Inpres Perumnas Antang II/I } \\ \text { Kelas/ Semester } & \text { : V/I } \\ \text { Hari/Tanggal } & \text { : Rabu / 01 Agustus } 2018 \\ \text { Mata Pelajaran } & \text { : Matematika } \\ \text { Alokasi Waktu } & : 3 \text { X } 35 \text { Menit }\end{array}$

A. Standar Kompetensi

1. Melakukan operasi hitung bilangan bulat dalam pemecahan masalah

B. Kompetensi Dasar

1.1 Melakukan operasi hitung bilangan bulat termasuk penggunaan sifat sifatnya, pembulatan dan penaksiran

C. Indikator

1. Mengidentifikasi sifat-sifat operasi hitung bilangan bulat

D. Tujuan Pembelajaran

1. Siswa dapat, mengidentifikasi sifat-sifat operasi hitung bilangan bulat

Karakter siswa yang diharapkan : Disiplin (Discipline), Rasa hormat

dan perhatian (respect), Tekun (diligence) dan Tanggung jawab

E. Materi Pembelajaran (responsibility)

Operasi hitung bilangan bulat

F. Model dan Metode Pembelajaran

1. Model : Auditory, Intellectually, Repetition (AIR)

2. Metode :Ceramah, tanya jawab, demonstrasi,diskusi dan penugasan

G. Sumber Belajar

1. Silabus dan KTSP 2006 Mata Pelajaran Matematika

2. Ali Masykur, dkk, 2016, Senang Belajar Matematika kelas V, Jakarta: Yudhistira 


\section{H. Kegiatan Pembelajaran}

\begin{tabular}{|c|c|}
\hline Kegiatan Pembelajaran & Waktu \\
\hline $\begin{array}{l}\text { A. Kegiatan Awal } \\
\text { 1. Salam pembuka } \\
\text { 2. Mengecek kebersihan kelas } \\
\text { 3. Berdoa } \\
\text { 4. Mengisi daftar hadir } \\
\text { 5. Apersepsi melalui sesi tanya jawab } \\
\text { 6. Menyampaikan tujuan pembelajaran }\end{array}$ & $\begin{array}{l}15 \text { menit } \\
\text { (Klasikal) } \\
\text { (Klasikal) } \\
\text { (Klasikal) } \\
\text { (Klasikal) } \\
\text { (Klasikal) } \\
\text { (Klasikal) }\end{array}$ \\
\hline $\begin{array}{l}\text { B. Kegiatan Inti } \\
\text { Tahap Auditory } \\
\text { 1. Guru membagi siswa menjadi beberapa kelompok } \\
\text { kecil } \\
\text { 2. Guru memberikan LKS kepada siswa untuk } \\
\text { dikerjakan secara kelompok } \\
\text { 3. Guru memberi kesempatan kepada siswa untuk } \\
\text { bertanya mengenai soal LKS yang kurang dipahami } \\
\text { Tahap Intellectually } \\
\text { 4. Guru membimbing kelompok belajar siswa untuk } \\
\text { berdiskusi dengan teman dalam satu kelompok } \\
\text { sehingga dapat menyelesaikan LKS } \\
\text { 5. Guru memberi kesempatan kepada beberapa } \\
\text { kelompok untuk mempresentasikan hasil kerjanya, } \\
\text { serta memberikan kesempatan kepada kelompok lain } \\
\text { untuk bertanya dan mengemukakan pendapatnya } \\
\text { Tahap Repetition } \\
\text { 6. Guru melakukan pengulangan dengan memberikan } \\
\text { latihan soal atau kuis individu kepada siswa baik } \\
\text { dengan lisan maupun tulisan }\end{array}$ & $\begin{array}{l}\text { (Klasikal) } \\
\text { (Klasikal) }\end{array}$ \\
\hline $\begin{array}{l}\text { C. Kegiatan Akhir } \\
\text { 1. Siswa dibimbing untuk menyimpulkan materi } \\
\text { pembelajaran } \\
\text { 2. Guru memberikan motivasi dan pesan-pesan moral } \\
\text { 3. Membaca doa } \\
\text { 4. Salam penutup }\end{array}$ & $\begin{array}{l}10 \text { menit } \\
\text { (Klasikal) } \\
\text { (Klasikal) } \\
\text { (Klasikal) } \\
\text { (Klasikal) }\end{array}$ \\
\hline
\end{tabular}

\section{Penilaian}

3. Teknik Penilaian

4. Instrumen Penilaian
: Tes tertulis

: Isian 


\section{J. Daftar Pustaka}

Ali Masykur, dkk, 2016, Senang Belajar Matematika kelas V, Jakarta: Yudhistira

Makassar, 01 Agustus 2018

Guru Kelas V

Peneliti

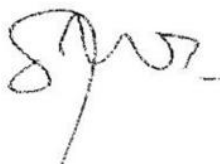

Nashrullah, S.Pd

Siti Nurfaidah

NIP. 198702142011011009

NIM: 093188793041

Mengetahui

Kepala SD Inpres Perumnas Antang II/I

$$
\text { Suharniati, S.Pd }
$$

NIP 196607091988032011 


\section{Lampiran 27}

\section{HASIL OBSERVASI KEGIATAN MENGAJAR GURU SIKLUS II PERTEMUAN KE-3}

$\begin{array}{ll}\text { Mata Pelajaran } & \text { : Matematika } \\ \text { Materi Pokok } & \text { : Operasi Hitung Bilangan Bulat } \\ \text { Nama Peneliti } & \text { : Siti Nurfaidah } \\ \text { Hari/Tanggal } & \text { : Rabu/ 01 Agustus 2018 }\end{array}$

Petunjuk : Berilah tanda centang $(\sqrt{ })$ pada kolom tersedia sesuai dengan pengamatan anda pada saat guru/peneliti melaksanakan pembelajaran.

\begin{tabular}{|c|c|c|c|c|c|c|}
\hline \multirow{2}{*}{ No } & \multirow{2}{*}{ Aktivitas yang diamati } & \multicolumn{5}{|c|}{ Skor } \\
\hline & & 1 & 2 & 3 & 4 & 5 \\
\hline 1 & Membuka pembelajaran dan mengucap salam & & & & & $\sqrt{ }$ \\
\hline 2 & $\begin{array}{l}\text { Mengkondisikan ruang kelas dan mempersiapkan } \\
\text { siswa untuk mengikuti pembelajaran. }\end{array}$ & & & & & $\sqrt{ }$ \\
\hline 3 & Mengajak siswa berdoa. & & & & & $\sqrt{ }$ \\
\hline 4 & Menyampaikan tujuan pembelajaran. & & & & & $\sqrt{ }$ \\
\hline 5 & Memberikan motivasi dan merumuskan masalah. & & & & $\sqrt{ }$ & \\
\hline 6 & Menyiapkan bahan ajar. & & & & & $\sqrt{ }$ \\
\hline 7 & $\begin{array}{l}\text { Membimbing siswa untuk mengumpulkan sebuah } \\
\text { informasi, }\end{array}$ & & & & $\sqrt{ }$ & \\
\hline 8 & Membagi kelompok diskusi. & & & & & $\sqrt{ }$ \\
\hline 9 & $\begin{array}{l}\text { Memimpin jalannya diskusi dan membimbing } \\
\text { kelompok diskusi }\end{array}$ & & & & $\sqrt{ }$ & \\
\hline 10 & $\begin{array}{l}\text { Menjelaskan tentang materi yang telah didiskusikan } \\
\text { dan melakukan timbal balik. }\end{array}$ & & & $\sqrt{ }$ & & \\
\hline 11 & Membimbing siswa untuk membuat kesimpulan. & & & & $\sqrt{ }$ & \\
\hline 12 & Memberikan test dan evaluasi & & & & $\sqrt{ }$ & \\
\hline 13 & Memberikan siswa kesempatan untuk bertanya. & & & & $\sqrt{ }$ & \\
\hline 14 & Membuat kesimpulan bersama siswa. & & & & $\sqrt{ }$ & \\
\hline 15 & Melaukan refleksi bersama dengan siswa. & & & $\sqrt{ }$ & & \\
\hline \multirow{2}{*}{\multicolumn{2}{|c|}{ Jumlah }} & 0 & 0 & 2 & 7 & 6 \\
\hline & & 0 & 0 & 6 & 28 & 30 \\
\hline & Total Perolehan Skor & \multicolumn{5}{|c|}{64} \\
\hline & Persentase Pelaksanaan Mengajar Guru & \multicolumn{5}{|c|}{$85,33 \%$} \\
\hline
\end{tabular}




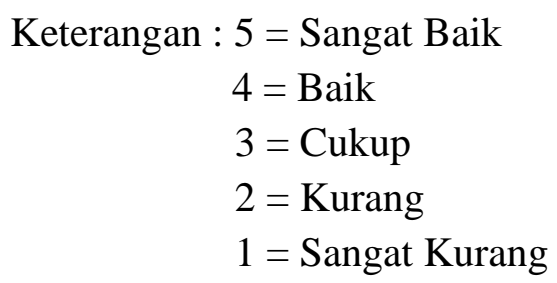

Persentase Pelaksanaan Kegiatan Mengajar Guru $=\frac{\text { total perolehan skor X }}{\text { ckor NakciNaS }} 100 \%$

$=\frac{64}{75} \times 100 \%=85,33 \%$

Makassar, 01 Agustus 2018

Observer

Guru Kelas V

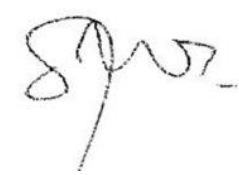

Nashrullah, S.Pd

NIP. 198702142011011009 


\section{Lampiran 28}

\section{HASIL OBSERVASI KEGIATAN BELAJAR SISWA SIKLUS II PERTEMUAN KE-3}

$\begin{array}{ll}\text { Mata Pelajaran } & \text { : Matematika } \\ \text { Materi Pokok } & \text { : Operasi Hitung Bilangan Bulat } \\ \text { Nama Peneliti } & \text { : Siti Nurfaidah } \\ \text { Hari/Tanggal } & \text { : Rabu/ 01 Agustus 2018 }\end{array}$

Petunjuk : Berilah tanda centang $(\sqrt{ })$ pada kolom tersedia sesuai dengan pengamatan anda pada saat guru/pebeliti melaksanakan pembelajaran.

\begin{tabular}{|c|c|c|c|c|c|c|}
\hline \multirow{2}{*}{ No } & \multirow{2}{*}{ Aktivitas yang diamati } & \multicolumn{5}{|c|}{ Skor } \\
\hline & & 1 & 2 & 3 & 4 & 5 \\
\hline 1 & Menjawab salam. & & & & & $\sqrt{ }$ \\
\hline 2 & Bersiap untuk mengikuti pembelajaran. & & & & & $\sqrt{ }$ \\
\hline 3 & Melaksanakan berdoa. & & & & & $\sqrt{ }$ \\
\hline 4 & $\begin{array}{l}\text { Mendengarkan tujuan pembelajaran yang } \\
\text { disampaikan guru. }\end{array}$ & & & & & $\sqrt{ }$ \\
\hline 5 & Siswa memperhatikan penjelasan guru. & & & & $\sqrt{ }$ & \\
\hline 6 & Siswa menyiapkan peralatan belajar. & & & & $\sqrt{ }$ & \\
\hline 7 & $\begin{array}{l}\text { Melakukan pengumpulan informasi dari yang sudah } \\
\text { di jelaskan guru. }\end{array}$ & & & $\sqrt{ }$ & & \\
\hline 8 & $\begin{array}{l}\text { Siswa duduk sesuai kelompok yang sudah dibagi } \\
\text { guru. }\end{array}$ & & & & $\sqrt{ }$ & \\
\hline 9 & $\begin{array}{l}\text { Siswa melakukan kegiatan diskusi yang dibimbing } \\
\text { guru. }\end{array}$ & & & & $\sqrt{ }$ & \\
\hline 10 & Siswa bekerja sama dengan teman kelompok. & & & & $\sqrt{ }$ & \\
\hline 11 & Siswa mempresentasikan hasil diskusinya. & & & & $\sqrt{ }$ & \\
\hline 12 & Siswa melaksanakan test dan evalusi dari guru & & & & $\sqrt{ }$ & \\
\hline 13 & Siswa melakukan tanya jawab dengan guru & & & & $\sqrt{ }$ & \\
\hline 14 & Menyimpulkan hasil diskusi dan pembelajaran. & & & $\sqrt{ }$ & & \\
\hline 15 & Melakukan refleksi bersama guru & & & $\sqrt{ }$ & & \\
\hline \multirow{2}{*}{\multicolumn{2}{|c|}{ Jumlah }} & 0 & 0 & 3 & 8 & 4 \\
\hline & & 0 & 0 & 9 & 32 & 20 \\
\hline & Total Perolehan Skor & \multicolumn{5}{|c|}{61} \\
\hline & Persentase Kegiatan Belajar Siswa & \multicolumn{5}{|c|}{$\mathbf{8 1 , 3 3 \%}$} \\
\hline
\end{tabular}




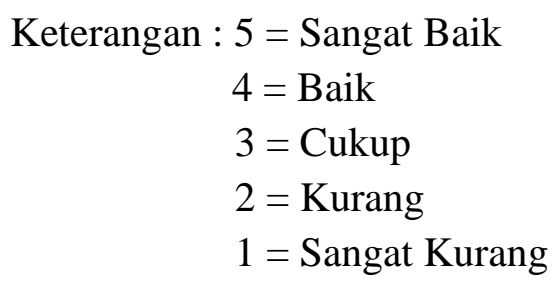

Persentase Kegiatan Belajar Siswa $=\frac{\text { total perolehan skor X }}{\text { ckor NakciNaS }} 100 \%$

$$
=\frac{61}{75} \times 100 \%=81,33 \%
$$

Makassar, 01 Agustus 2018

Observer

Guru Kelas V

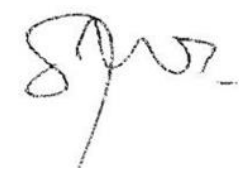

Nashrullah, S.Pd

NIP. 198702142011011009 
Lampiran 29

\section{EVALUASI (TES FORMATIF)}

SIKLUS II

Nama Siswa :

Kelas

SOAL!

3. Gambarlah garis bilangan beserta keterangannya!

4. $-9+(-12)=$

5. $6+(-4)=$

6. $4-11=$

7. $-12-(-8)=$

8. $6 \times 4=$

9. $-4 \times 13=$

10. $-5 \times(-11)=$

$11.5 \times(-7)=$

12. $-13 \times 4=$ 


\section{RAMBU-RAMBU JAWABAN}

3. -Semakin ke kanan nilai bilangan semakin besar

-Semakin ke kiri nilai bilangan semakin kecil

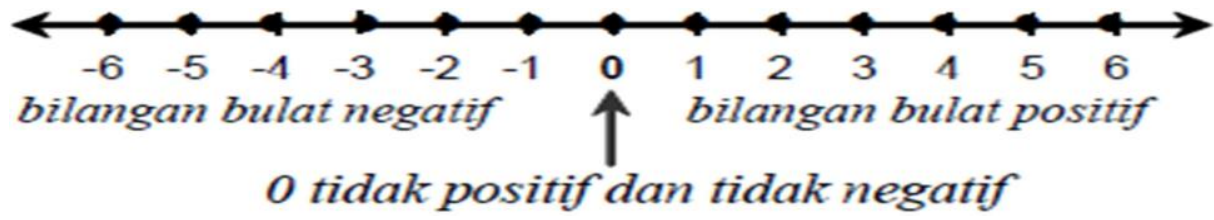

4. $-9+(-12)=-21$

5. $6+(-4)=2$

6. $4-11=-7$

7. $-12-(-8)=-4$

8. $6 \times 4=24$

9. $-4 \times 13=-52$

10. $-5 \times(-11)=55$

11. $5 \times(-7)=-35$

12. $-13 \times 4=-52$

\section{PEDOMAN PENSKORAN}

- Soal nomor 1-10 (masing-masing skor 10$)$, skor maksimal $=100$

- Skor 10, jika jawaban benar.

- Skor 5, jika jawaban kurang benar.

- Skor 0, jika jawaban salah/tidak menjawab sama sekali.

Nilai

$$
=\frac{\text { Skor Perolehan }}{\text { Skor Maksimal }} \times 100 \%
$$


Lampiran 30

Kisi-Kisi Soal Matematika

\begin{tabular}{|c|c|c|c|}
\hline Standar Kompetensi & Kompetensi Dasar & Indikator & $\begin{array}{c}\text { Nomor } \\
\text { Soal }\end{array}$ \\
\hline $\begin{array}{l}\text { Bilangan } \\
\text { 1. Melakukan operasi } \\
\text { hitung bilangan } \\
\text { bulat dalam } \\
\text { pemecahan } \\
\text { masalah }\end{array}$ & $\begin{array}{l}\text { 1.1Melakukan } \\
\text { operasi hitung } \\
\text { bilangan bulat } \\
\text { termasuk } \\
\text { penggunaan } \\
\text { sifat-sifatnya, } \\
\text { pembulatan dan } \\
\text { penaksiran }\end{array}$ & 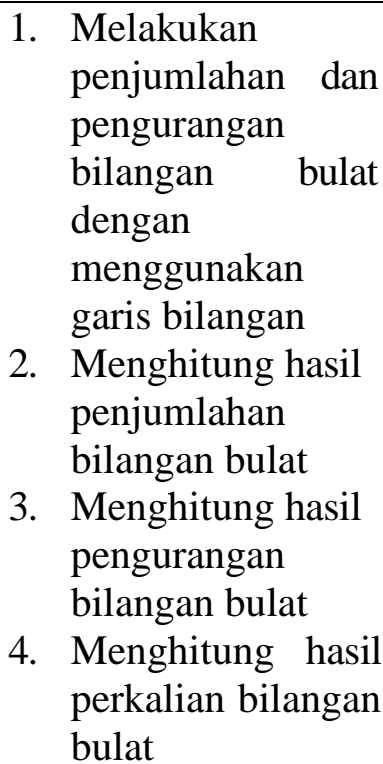 & $\begin{array}{l}3,4,5 \\
6,7,8 \\
9,10\end{array}$ \\
\hline
\end{tabular}




\section{Lampiran 31}

PEROLEHAN SKOR EVALUASI (TES FORMATIF)

SIKLUS II

\begin{tabular}{|c|c|c|c|c|c|}
\hline \multirow[t]{2}{*}{ No. } & \multirow[t]{2}{*}{ Nama Siswa } & \multicolumn{2}{|c|}{$\begin{array}{c}\text { Nomor } \\
\text { Soal/Skor }\end{array}$} & \multirow{2}{*}{$\begin{array}{c}\text { Jumlah } \\
\text { Skor }\end{array}$} & \multirow[t]{2}{*}{ Keterangan } \\
\hline & & $1-5 / 50$ & $6-10 / 50$ & & \\
\hline 1. & Densel & 25 & 50 & 75 & Tuntas \\
\hline 2. & Muh. Henson & 35 & 40 & 75 & Tuntas \\
\hline 3. & Katara & 25 & 40 & 65 & Tidak Tuntas \\
\hline 4. & A. Alfatia Alya R & 35 & 40 & 75 & Tuntas \\
\hline 5. & Ayu Permata Sari & 35 & 50 & 85 & Tuntas \\
\hline 6. & Andy Ryan Mahendra & 30 & 50 & 80 & Tuntas \\
\hline 7. & A. Nur Azizah & 40 & 40 & 80 & Tuntas \\
\hline 8. & Aurellia D.V & 40 & 50 & 90 & Tuntas \\
\hline 9. & A.Nur Asmaul & 30 & 50 & 80 & Tuntas \\
\hline 10. & Abyan & 40 & 50 & 90 & Tuntas \\
\hline 11. & Muh. Fahri & 40 & 40 & 80 & Tuntas \\
\hline 12. & Nur Hikmah Nurdin & 40 & 50 & 90 & Tuntas \\
\hline 13. & Nabila Alya & 40 & 45 & 85 & Tuntas \\
\hline 14. & Nur Aisyah & 30 & 50 & 80 & Tuntas \\
\hline 15. & Alfira Maharani & 40 & 40 & 80 & Tuntas \\
\hline 16. & Ainal Syahputra & 50 & 35 & 85 & Tuntas \\
\hline 17. & Humaira Natasha & 40 & 40 & 80 & Tuntas \\
\hline 18. & Al Ifti Nur Wasisah & 35 & 50 & 85 & Tuntas \\
\hline 19. & Nur Syafika Apriliyani & 30 & 50 & 80 & Tuntas \\
\hline 20. & Rasya & 35 & 50 & 85 & Tuntas \\
\hline 21. & Asnidar Tri Barata & 35 & 50 & 85 & Tuntas \\
\hline 22. & Afgan Dulfian & 25 & 50 & 75 & Tuntas \\
\hline 23. & Ghulam Sultan Dafi & 40 & 40 & 80 & Tuntas \\
\hline 24. & Dwi Yana Aulia & 40 & 40 & 80 & Tuntas \\
\hline 25. & Nur Aristia Aprilia & 20 & 45 & 65 & Tidak Tuntas \\
\hline
\end{tabular}




\begin{tabular}{|c|c|c|c|c|c|}
\hline \multirow{2}{*}{ No. } & \multirow{2}{*}{ Nama Siswa } & \multicolumn{2}{|c|}{$\begin{array}{c}\text { Nomor } \\
\text { Soal/Skor }\end{array}$} & \multirow{2}{*}{$\begin{array}{c}\text { Jumlah } \\
\text { Skor }\end{array}$} & \multirow{2}{*}{ Keterangan } \\
\hline & & $1-5 / 50$ & $\begin{array}{l}6- \\
10 / 50\end{array}$ & & \\
\hline 26. & Annisa Zaharani & 45 & 40 & 85 & Tuntas \\
\hline 27. & Arham Syahputra & 45 & 40 & 85 & Tuntas \\
\hline 28. & Nurjannah A.S & 30 & 50 & 80 & Tuntas \\
\hline 29. & Fitri Dwi Handayani & 35 & 40 & 75 & Tuntas \\
\hline 30. & Muh. Farel & 25 & 50 & 75 & Tuntas \\
\hline \multicolumn{4}{|c|}{ Jumlah } & 2410 & \multirow{3}{*}{$\begin{array}{c}\text { Tuntas } \\
\text { (Sangat } \\
\text { Baik) }\end{array}$} \\
\hline \multicolumn{4}{|c|}{ Rata-rata } & 80,33 & \\
\hline \multicolumn{4}{|c|}{ Persentase Ketuntasan Belajar } & $93,33 \%$ & \\
\hline
\end{tabular}

Rata-rata

$$
=\frac{\text { Jumlah skor }}{\text { Jumlah siswa keseluruhan }}=\frac{2410}{30}=80,33
$$

Persentase Ketuntasan Belajar $\frac{\text { Jumah siswa yang tuntas }}{\text { Jumlah siswa keseluruhan }} \times 100 \%=\frac{28}{30} \times 100 \%$ 


\section{Lampiran 32}

REKAPITULASI PEROLEHAN NILAI MATEMATIKA

\begin{tabular}{|c|c|c|c|}
\hline \multirow{2}{*}{$\begin{array}{c}\text { No } \\
\text {. }\end{array}$} & \multirow{2}{*}{ Nama Siswa } & \multicolumn{2}{|c|}{ Nilai Siswa } \\
\hline & & Siklus I & Siklus II \\
\hline 1. & Densel & 45 & 75 \\
\hline 2. & Muh. Henson & 65 & 75 \\
\hline 3. & Katara & 65 & 65 \\
\hline 4. & A. Alfatia Alya R & 65 & 75 \\
\hline 5. & Ayu Permata Sari & 55 & 85 \\
\hline 6. & Andy Ryan Mahendra & 60 & 80 \\
\hline 7. & A. Nur Azizah & 75 & 80 \\
\hline 8. & Aurellia D.V & 80 & 90 \\
\hline 9. & A.Nur Asmaul & 70 & 80 \\
\hline 10. & Abyan & 75 & 90 \\
\hline 11. & Muh. Fahri & 45 & 80 \\
\hline 12. & Nur Hikmah Nurdin & 80 & 90 \\
\hline 13. & Nabila Alya & 70 & 85 \\
\hline 14. & Nur Aisyah & 75 & 80 \\
\hline 15. & Alfira Maharani & 75 & 80 \\
\hline 16. & Ainal Syahputra & 75 & 85 \\
\hline 17. & Humaira Natasha & 70 & 80 \\
\hline 18. & Al Ifti Nur Wasisah & 70 & 85 \\
\hline 19. & Nur Syafika Apriliyani & 75 & 80 \\
\hline 20. & Rasya & 75 & 85 \\
\hline 21. & Asnidar Tri Barata & 80 & 85 \\
\hline 22. & Afgan Dulfian & 55 & 75 \\
\hline 23. & Ghulam Sultan Dafi & 40 & 80 \\
\hline 24. & Dwi Yana Aulia & 50 & 80 \\
\hline 25. & Nur Aristia Aprilia & 45 & 65 \\
\hline 26. & Annisa Zaharani & 75 & 85 \\
\hline 27. & Arham Syahputra & 75 & 85 \\
\hline
\end{tabular}




\begin{tabular}{|l|l|c|c|}
\hline \multirow{2}{*}{$\begin{array}{c}\text { No } \\
\bullet\end{array}$} & \multicolumn{1}{|c|}{ Nama Siswa } & \multicolumn{2}{|c|}{ Nilai Siswa } \\
\cline { 2 - 4 } & Siklus I & Siklus II \\
\hline 28. & Nurjannah A.S & 70 & 80 \\
\hline 29. & Fitri Dwi Handayani & 65 & 75 \\
\hline 30. & Muh. Farel & 65 & 75 \\
\hline Jumlah & $\mathbf{1 9 4 0}$ & $\mathbf{2 4 1 0}$ \\
\hline Rata-rata Kelas & $\mathbf{6 4 , 6 7}$ & $\mathbf{8 0 , 3 3}$ \\
\hline Persentase Ketuntasan Belajar & $\mathbf{5 3 , 3 3 \%}$ & $\mathbf{9 3 , 3 3 \%}$ \\
\hline $\begin{array}{l}\text { Persentase Ketidaktuntasan } \\
\text { Belajar }\end{array}$ & $\mathbf{4 6 , 6 7 \%}$ & $\mathbf{6 , 6 7 \%}$ \\
\hline $\begin{array}{l}\text { Persentase Selisih Ketuntasan } \\
\text { Belajar }\end{array}$ & \multicolumn{2}{|c}{} \\
\hline
\end{tabular}




\section{Lampiran 33}

\section{Foto Pelaksanaan Penelitian}

Peningkatan Hasil Belajar Matematika Melalui Model Pembelajaran Auditory, Intellectually, Repetition (AIR) Pada Siswa Kelas V SD Inpres

Perumnas Antang II/I Kota Makassar

\section{Lokasi Penelitian}

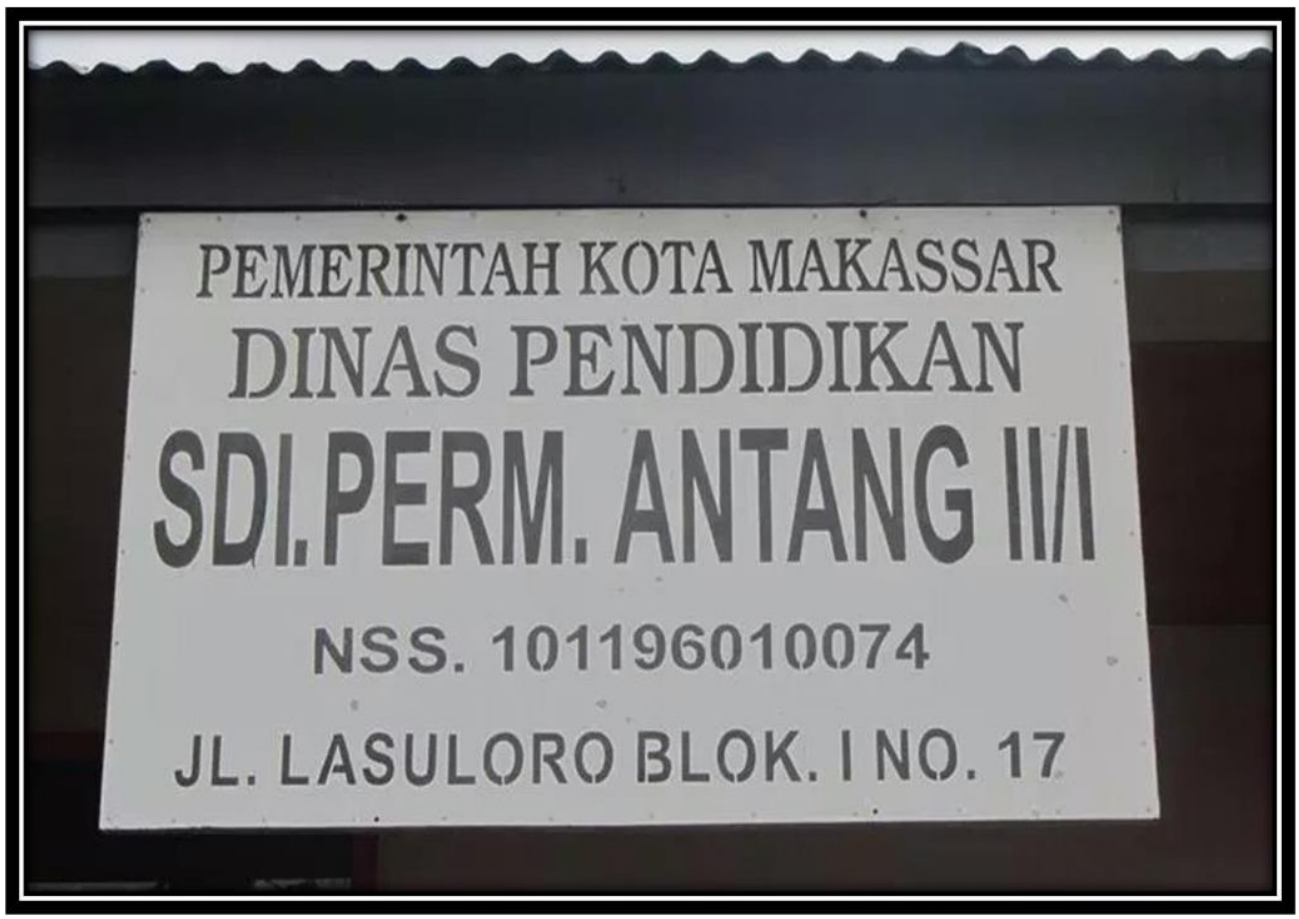


Tahapan Model Pembelajaran Auditory, Intellectually, Repetition (AIR)

Dalam Proses Pembelajaran Matematika

Tahap I: Tahap Auditory

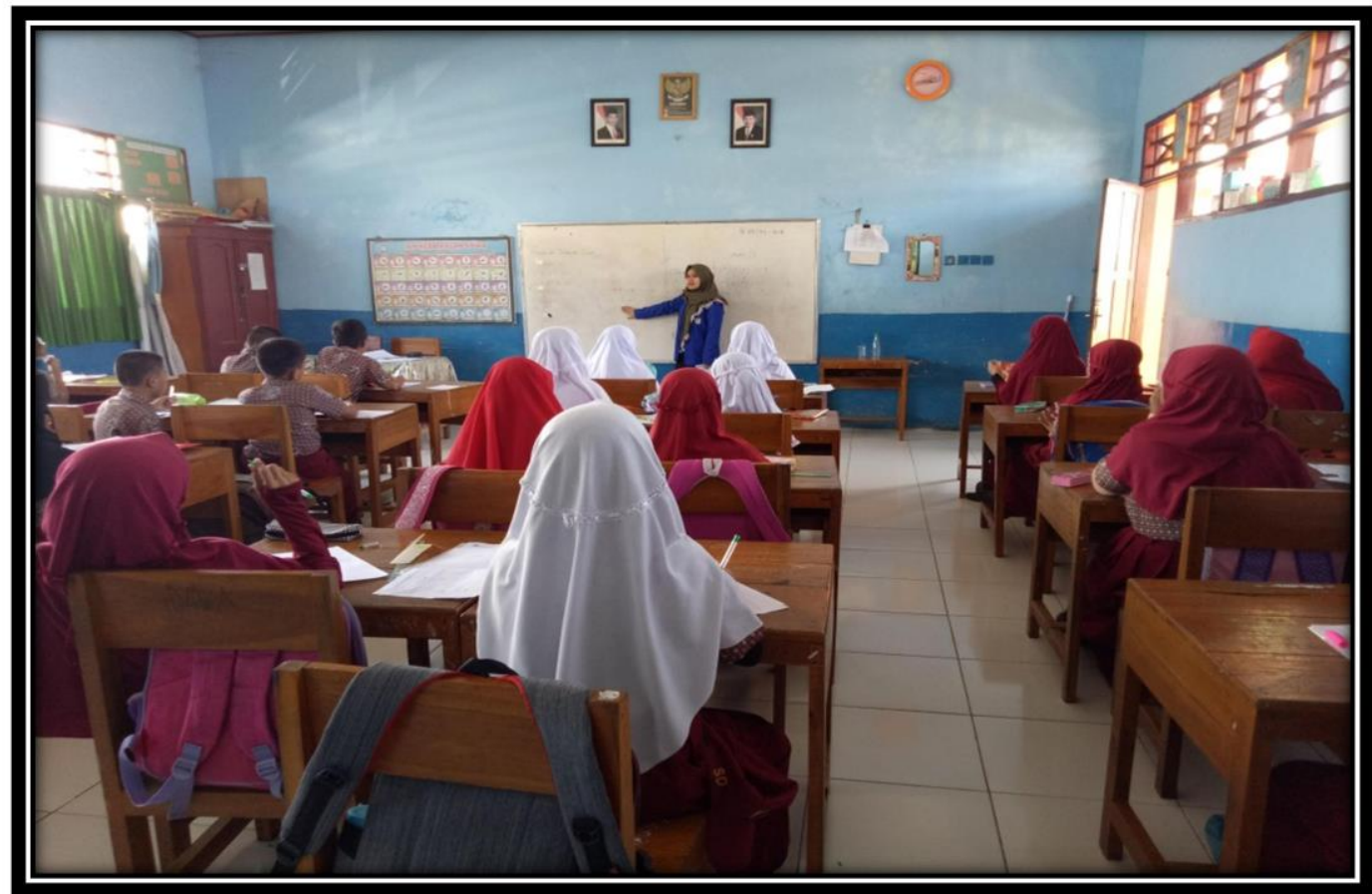

Dokumentasi: Guru Menjelaskan Materi

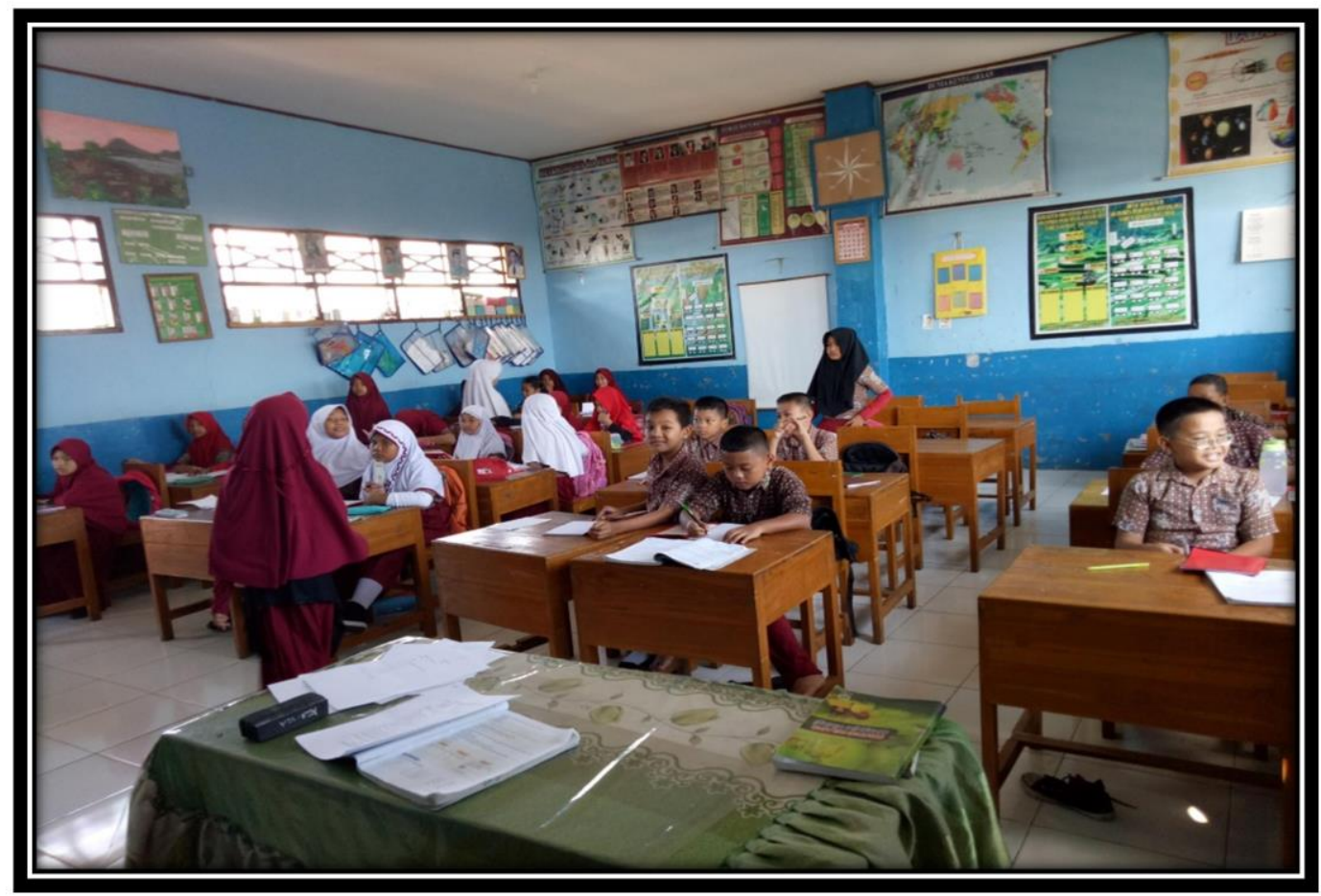

Dokumentasi: Guru Membagikan LKS untuk dikerjakan kelompok 
Tahap II: Tahap Intellectually
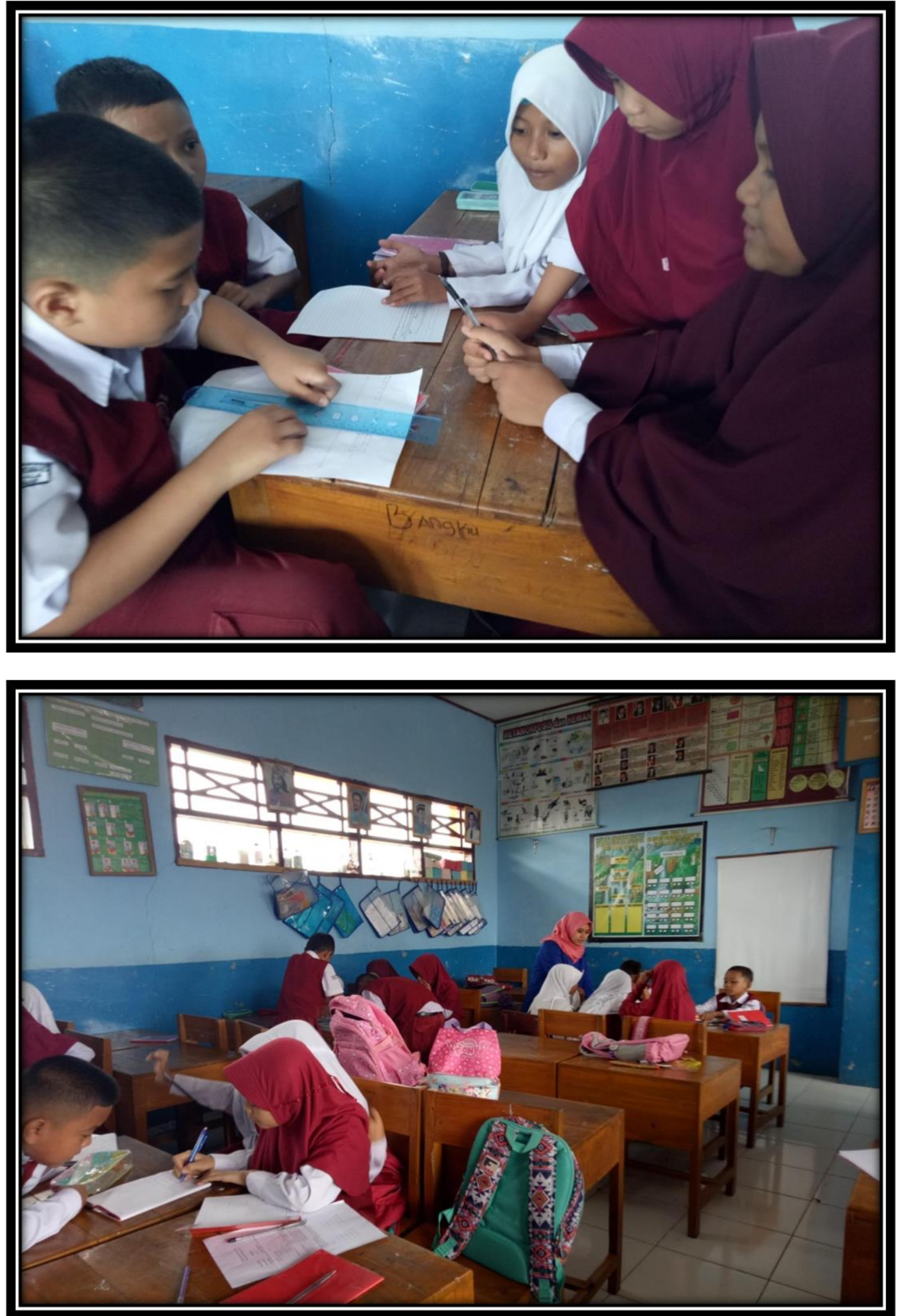

Dokumentasi: Guru Membimbing Kelompok Belajar Siswa 
Tahap III: Tahap Reptition
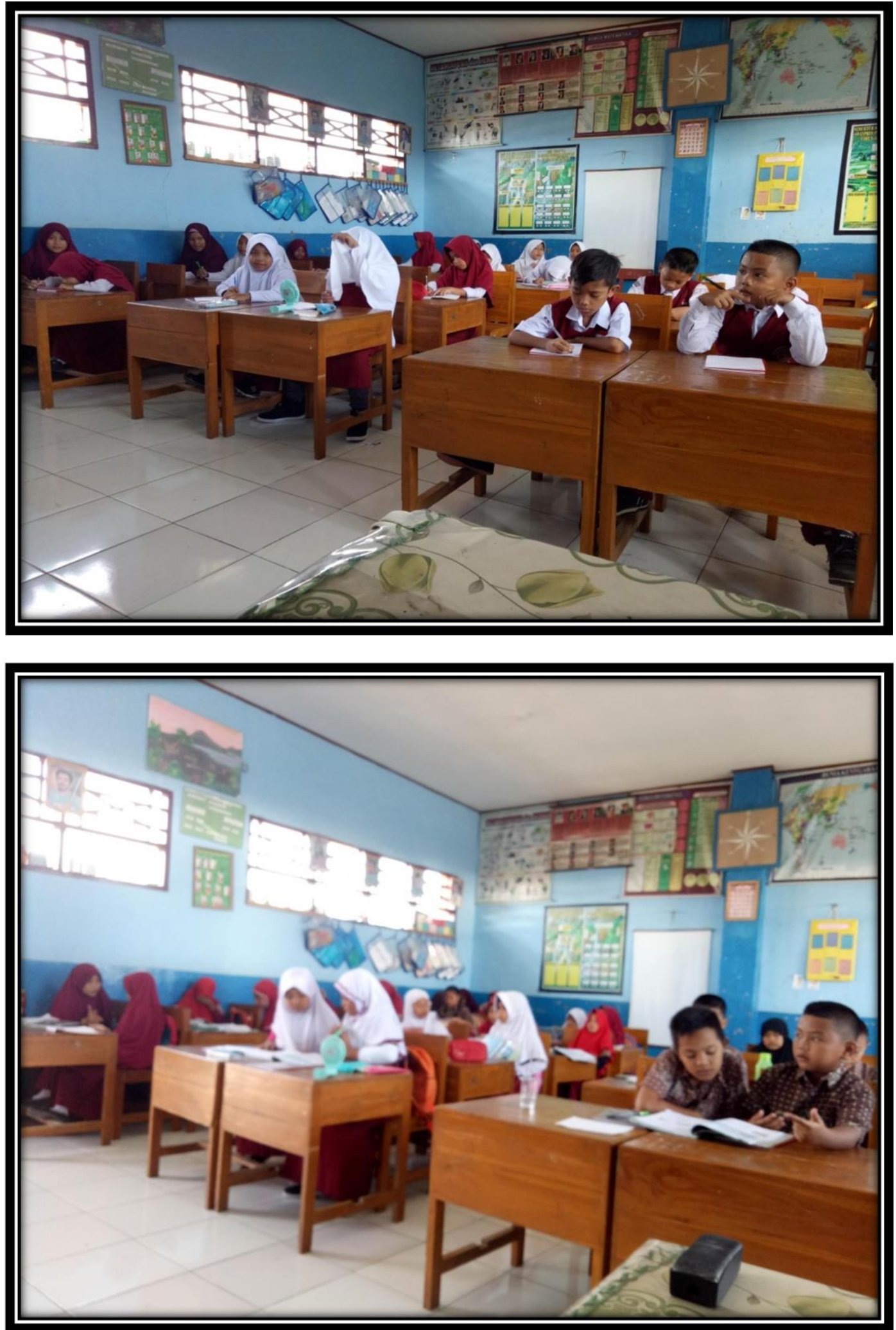

Dokumentasi: Guru Memberikan Latihan Soal Individu 


\section{Lampiran 34}

\section{SURAT IZIN PENELITIAN}

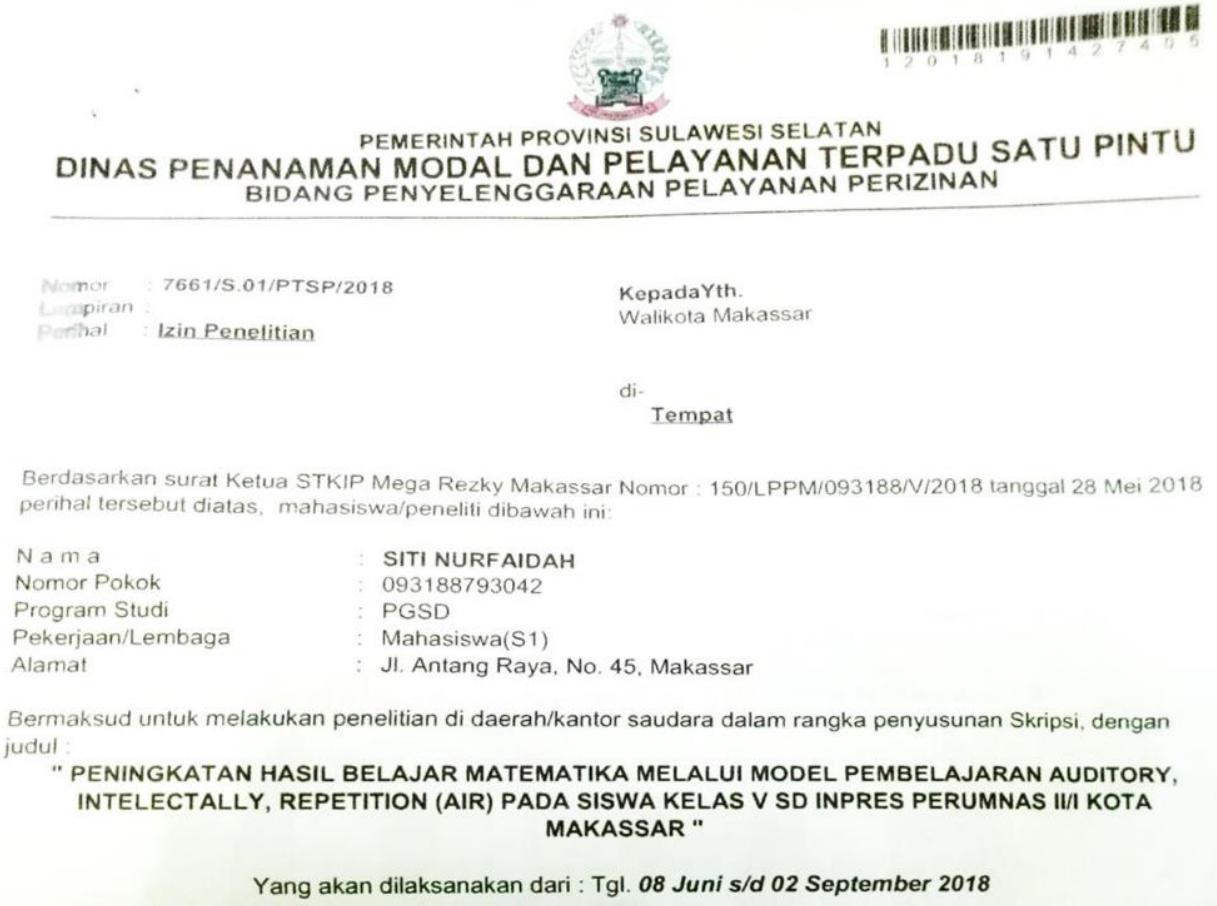

Bermaksud untuk melakukan penelitian di daerah/kantor saudara dalam rangka penyusunan Skripsi, dengan judul

" PENINGKATAN HASIL BELAJAR MATEMATIKA MELALUI MODEL PEMBELAJARAN AUDITORY, INTELECTALLY, REPETITION (AIR) PADA SISWA KELAS V SD INPRES PERUMNAS II/ KOTA MAKASSAR "

Yang akan dilaksanakan dari : Tgl. 08 Juni s/d 02 September 2018

Sehubungan dengan hal tersebut diatas, pada prinsipnya kami menyetujui kegiatan dimaksud dengan ketentuan yang tertera di belakang surat izin penelitian.

Demikian Surat Keterangan ini diberikan agar dipergunakan sebagaimana mestinya.

Diterbitkan di Makassar

Pada tanggal : 08 Juni 2018

A.n. GUBERNUR SULAWESI SELATAN

KEPALA DINAS PENANAMAN MODAL DAN PELAYANAN TERPADU SATU

PINTU PROVINSI SULAWESI SELATAN

Selaku Administrator Pelayanan Perizinan Terpadu

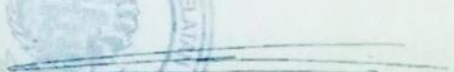

A.M. YAMIN. SE, MS.

Pangkat : Pembina Utama Madya Nip : 196105131990021002 


\section{PEMERINTAH KOTA MAKASSAR BADAN KESATUAN BANGSA DAN POLITIK \\ Jalan Ahmad Yani No 2 Makassar 9011 \\ Celp +62411 - 3615867 Fax +62411-361586 \\ Email Kesbang@makassar.go.ld Home page http.www.makassar.go.id

Makassar. 25 Juni 2018

Ke p a d a

$\begin{array}{lll}\text { Nomor } & 070 / / 68-11 / B K B P N 1 / 2018 \\ \text { Sifat } & \end{array}$

Perihal : Izin Penelitian
Yth. KEPALA DINAS PENDIDIKAN KOTA MAKASSAR

Di -

MAKASSAR

Dengan Hormat

Menunjuk Surat dari Kepala Dinas Koordinası Penanaman Modal Daerah Provinsi Sulawesi Selatan Nomor : 7661/S.01/PTSP/2018 Tanggai 08 Juni 2018 Perihal tersebut di atas, maka bersama inı disampaikan kepada Bapak bahwa

NAMA

NIM/ Jurusan : : 093188793042 / PGSD

Pekerjaan : Mahasiswa (S1) / STKIP Mega Rezky

Alamat : Jl. Antang Raya No. 45, Makassar

Judul

"PENINGKATAN HASIL BELAJAR MATEMATIKA MELALUI MODEL PEMBELAJARAN AUDITORY, INTELECTALLY, REPETITION (AIR) PADA SISWA KELAS KELAS V SD INPRES PERUMNAS II/I KOTA MAKASSAR"

Bermaksud mengadakan Penelitian pada Instansi / Wilayah Bapak, dalam rangka Penyusunan Skripsi sesuai dengan judul di atas, yang akan dilaksanakan mulai tanggal 25 Juni s/d 02 September 2018.

Sehubungan dengan hal tersebut, pada prinsipnya kami dapat menyetujui dengan memberikan surat rekomendasi izin penelitian ini dan harap diberikan bantuan dan fasilitas seperlunya.

Demikian disampaikan kepada Bapak untuk dimaklumi dan selanjutnya yang bersangkutan melaporkan hasilnya kepada Walikota Makassar Cq. Kepala Badan Kesatuan Bangsa dan Politik.
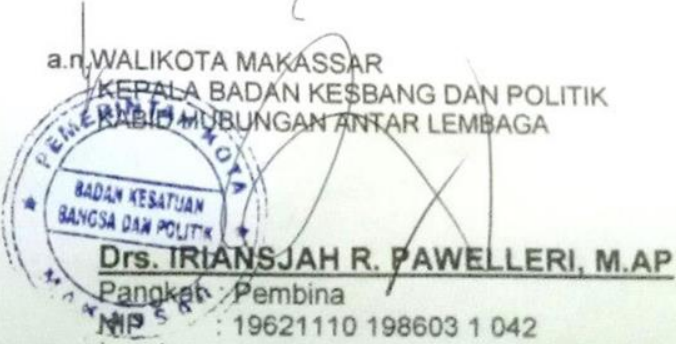

Tembusan :

1. Kepala Badan Kesatuan Bangsa dan Politik Prop. Sul - Sel. di Makassar

2. Kepala Unit Pelaksana Teknis P2T Badan Koordinasi Penanaman Modal Daerah Prop Sul Sel di Makassar

3. Ketua STKIP Mega Rezky Makassar Makassar,

4 Mahasiswa yang Dersengkutan: 


\section{PEMERINTAH KOTA MAKASSAR DINAS PENDIDIKAN}

\section{IZIN PENELITIAN \\ NOMOR : 070/0449/DP/VI/2018}

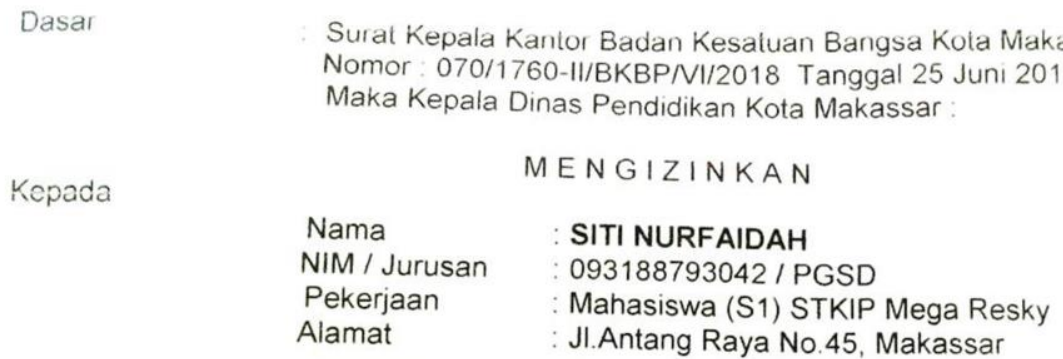

Untuk

Mengadakan Penelitian di SD Inpres Perumnas IIII Kota Makassar dalam rangka Penyusunan Skripsi di STKIP Mega Resky Makassar dengan judul penelitian:

"PENINGKATAN HASIL BELAJAR MATEMATIKA MELALUI MODEL PEMBELAJARAN AUDITORY,INTELECTUALLY,REPETITION (AIR) PADA SISWA KELAS V SD INPRES PERUMNAS // KOTA MAKASSAR"

Dengan Ketentuan sebagai berikut

1. Harus melapor pada Kepala Sekolah yang bersangkutan

2. Tidak mengganggu proses kegiatan belajar mengajar di Sekola $\mathrm{h}$

3. Harus mematuhi tata tertib dan peraturan di Sekolah yang berlaku 4. Hasil penelitian 1 ( satu ) examplar di laporkan kepada Kepala Dinas Pendidikan Kota
Makassar

Demikian izin penelitian ini di berikan untuk di gunakan sebagaimana mestinya

Dikeluarkan di : Makassar

Pada Tanggal : 29 Juni 2018

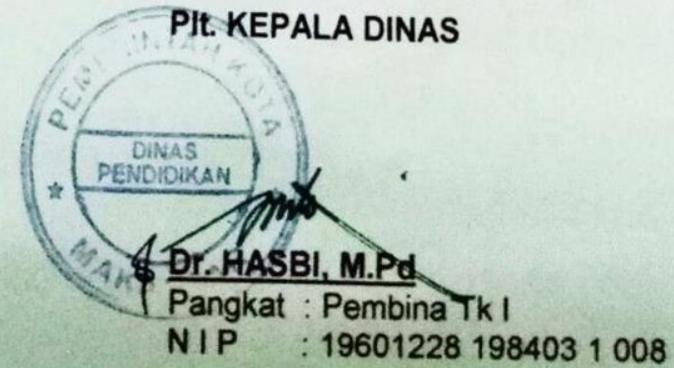


Lampiran 35

\section{SURAT KETERANGAN PENELITIAN}

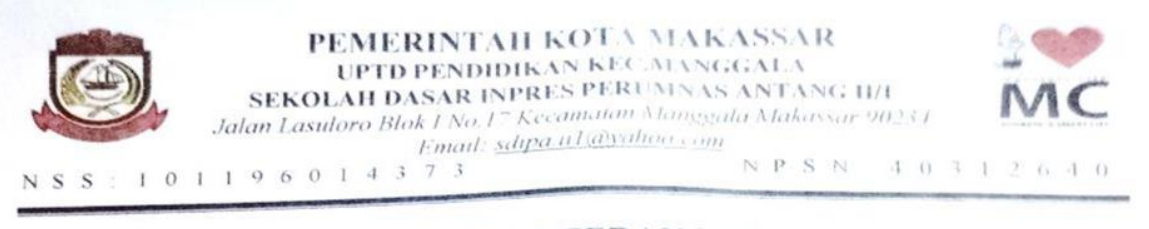

\section{$\frac{\text { SURAT KETERANGAN }}{\text { Nomor } 421.2 / 055 / \text { SDI.PA } 11 / 1 / \text { VI11/2018 }}$}

Berdasarkan

070/0449/DP/VI/2018 oleh Dinas Pendidikan Kota Matantit

Tanggal 29 Juni 2018 Maka yang bertanda tangan dibawah in

$\begin{array}{ll}\text { Nama } & \text { Suharniati, S.Pd. } \\ \text { NIP } & \text { : } 196607091988032011 \\ \text { Pangkat/Gol } & : \text { Pembina Tk.I/IV.b } \\ \text { Jabatan } & \text { : Kepala Sekolah }\end{array}$

Dengan ini menyatakan bahwa mahasiswa yang bernama dibawah ini:
Nama
Siti Nurfaidah
NIM
093188793042
Prodi
: PGSD
Universitas : STKIP Mega Rezky

Benar telah melakukan pengambilan data dan penelitian dengan judul "Peningkatan Hasil Belajar Matematika Melalui Model Pembelajaran Auditory, Intelectually, Repetition (AIR) Pada Siswa Kelas V SD Inpres Perumnas Antang II/1 Kota Makassar", berdasarkan surat izin yang telah diberikan terhitung mulai tanggal 29 Juni 2018 sampai dengan 14 Agustus 2018.

Demikian surat ini diberikan kepada yang bersangkutan untuk digunakan sebagaimana mestinya

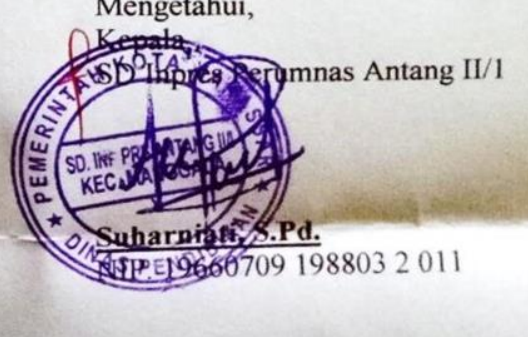




\section{RIWAYAT HIDUP}

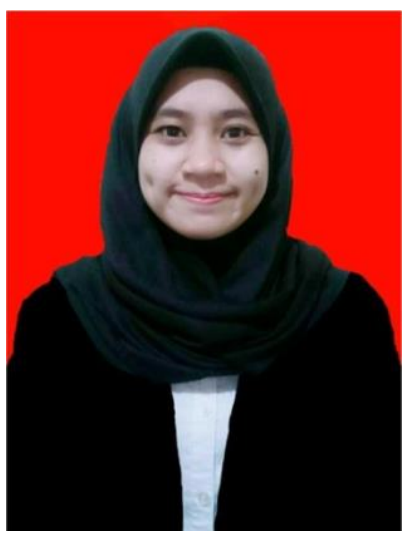

SITI NURFAIDAH, lahir di Ujung Pandang, Provinsi Sulawesi Selatan pada tanggal 23 Juli 1996. Putri kedua dari tiga bersaudara dari pasangan Bapak Syaharuddin Yahya dan Ibu Suryani. Pada tahun 2002 penulis memasuki jenjang pendidikan di SD Inpres Perumnas Antang II/I Kota Makassar dan tamat pada tahun 2008. Kemudian melanjutkan pendidikan di SMP Negeri 17 Makassar dan selesai pada tahun 2011. Penulis kembali menempuh pendidikan di SMA Negeri 10 Makassar pada tahun 2011-2014. Pada tahun 2014 terdaftar sebagai mahasiswa Sarjana (S1) Jurusan Pendidikan Guru Sekolah Dasar (PGSD) di Sekolah Tinggi Keguruan dan Ilmu Pendidikan (STKIP) Mega Rezky Makassar. Selama dalam lingkup kampus, penulis ikut dalam organisasi internal kampus yaitu PRAMUKA. 